UNIVERSIDADE DE SÃO PAULO

FACULDADE DE EDUCAÇÃO

FERNANDA GUINOZA MATUDA

TELECENTRO COMUNITÁRIO COMO ESPAÇO DE EDUCAÇÃO SOCIAL: UM ESTUDO DE CASO

São Paulo

FEUSP

2008 
FERNANDA GUINOZA MATUDA

\title{
TELECENTRO COMUNITÁRIO COMO ESPAÇO DE EDUCAÇÃO SOCIAL: UM ESTUDO DE CASO
}

\author{
Dissertação apresentada ao Programa de Pós-Graduação \\ da Faculdade de Educação da Universidade de São \\ Paulo como pré-requisito para obtenção do título \\ acadêmico de Mestre em Educação.
}

Linha de Pesquisa: Estado, Sociedade e Educação

Orientador: Prof. Dr. Roberto da Silva

São Paulo

FEUSP

2008 
Autorizo a reprodução e divulgação total ou parcial deste trabalho, por qualquer meio convencional ou eletrônico, para fins de estudo e pesquisa, desde que citada a fonte.

Catalogação na Publicação Serviço de Biblioteca e Documentação

Faculdade de Educação da Universidade de São Paulo

371.369(81.61) Matuda, Fernanda Guinoza

M445t Telecentro comunitário como espaço de educação social : um estudo de caso / Fernanda Guinoza Matuda ; orientação Roberto da Silva. São Paulo : s.n., 2008.

139 p. : il. + anexos.

Dissertação (Mestrado - Programa de Pós-Graduação em Educação.Área de Concentração : Estado, Sociedade e Educação) - - Faculdade de Educação da Universidade de São Paulo.

1. Inclusão digital - São Paulo, SP 2. Tecnologia da informação - Educação 3. Computador no ensino 4. Educação Aspectos sociais 5. Centros comunitários I. Silva, Roberto da, orient. 


\section{FOLHA DE APROVAÇÃO}

Fernanda Guinoza Matuda

Telecentro comunitário como espaço de Educação Social: um estudo de caso

Dissertação apresentada ao Programa de PósGraduação da Faculdade de Educação da Universidade de São Paulo como pré-requisito para obtenção do título acadêmico de Mestre em Educação.

Linha de Pesquisa: Estado, Sociedade e Educação

Orientador: Prof. Dr. Roberto da Silva

Aprovado em:

\section{Banca Examinadora}

Prof. Dr.

Assinatura:

Instituição:

Prof. Dr.

Assinatura:

Instituição:

Prof. Dr.

Assinatura:

Instituição:

Prof. Dr.

Assinatura:

Instituição: 
Dedicatória

Dedico este trabalho a todos que contribuíram para a minha formação: pais, irmãs, amigos e tantos outros que encontrei nos caminhos da vida.

Dedico também aos velhos e novos excluídos do mundo, sejam eles excluídos sociais elou digitais. 


\section{Agradecimentos}

A Deus por me criar com esta mente inquieta e cheia de vontade de transformar o mundo.

Aos meus pais e todos os verdadeiros amigos pelo cuidado e paciência em ouvir cada capítulo desta novela.

À Carol e à Tati pelas orientações, ainda que fossem de outras áreas, e por todas as conversas de sempre.

Ao Prof. Dr. Roberto da Silva pela paciência e dedicação na orientação desde antes do mestrado e por me mostrar o caminho até a Cidade Tiradentes, lugar onde desenvolvi essa pesquisa. Pelas longas conversas no caminho para a Zona Leste e pelo exemplo de vida e superação. Pelos trabalhos que realizamos e pelo sonho do Congresso de Pedagogia Social que se tornou verdade.

Aos professores doutores Sérgio Amadeu da Silveira (Fundação Cásper Líbero) e Maurício Pietrocola Pinto de Oliveira (FEUSP) pelas pertinentes e esclarecedoras orientações na Banca de Qualificação.

À Secretaria da Educação do Estado de São Paulo pelo apoio do Programa Bolsa Mestrado e aos colegas da Oficina Pedagógica das Diretorias de Ensino Centro Sul e Centro Oeste pelo acolhimento.

Ao Andrey Serra por toda ajuda com os números desta pesquisa e aos demais colegas do Programa Bolsa Mestrado com quem compartilhei bons e difíceis momentos dessa fase.

A todos os colegas do Projeto Febem, onde tudo começou, especialmente à Marina Fernanda Menezes e ao Reginaldo Hideaki Kamya com quem trabalhei mais de perto.

À amiga Juliana Gama Izar pelas longas conversas ao telefone e na Internet.

Ao Diego Amoroso pela paciência e cuidado em me apoiar na pesquisa de campo e a todos os usuários entrevistados por todo carinho e respeito à pesquisa.

E, em especial, a todos os amigos do Instituto Pombas Urbanas pela acolhida carinhosa, permitindo-me desenvolver esta pesquisa no telecentro e dando-me a oportunidade de trabalharmos juntos em tantos projetos. Pessoas admiráveis com quem aprendi valores e que me fizeram continuar acreditando em um outro mundo possível. 


\section{Resumo}

O surgimento de novas Tecnologias da Informação e Comunicação (TIC) tem levantando diversas análises e estudos sobre as relações sociais na atualidade. O acesso aos recursos tecnológicos se constitui em um forte instrumento de dominação, uma vez que não está ao alcance de todos. Um dos mecanismos criados na tentativa de minimizar a exclusão digital são os chamados telecentros comunitários, que disponibilizam acesso às tecnologias por parte da população menos privilegiada. É uma ação bastante empregada nos programas de Inclusão Digital da cidade de São Paulo - SP que possui somente $25,47 \%$ de sua população incluída digitalmente. Esta pesquisa se configura como um estudo de caso, realizado em um telecentro localizado na Zona Leste de São Paulo e teve como objetivo investigar se este equipamento pode ser compreendido como um espaço de Educação Social. A pesquisa de campo foi realizada por meio de questionário semi-estruturado, com amostra de 115 usuários. A análise dos dados coletados indicou que existe aprendizagem de dois tipos de conteúdos no local: informática e relações sociais mediadas ou não pelo computador. Os conteúdos aprendidos apontaram a especificidade da Educação no telecentro - a cultura digital. Embora tenha sido possível verificar melhora na utilização dos recursos tecnológicos com o telecentro, o estudo aponta a necessidade de um projeto político e pedagógico como mecanismo para otimizar as ações desenvolvidas no local, pontuando que este trabalho, longe de ser caracterizado por uma prática não-formal, tem objeto próprio e é intencional.

Palavras-chave: Inclusão Digital, Educação Social, telecentro comunitário. 


\begin{abstract}
The appearance of new Information and Communication Technologies has been discussed in several analyses and studies about the social relations in the present. The access to these technologies can be considered as a strong instrument of domination because a lot of people don't have means to benefit from these resources. The telecentres are a manner to reduce the digital exclusion because they allow the destitute population to have access technologies. This project has been widely introduced in São Paulo city, where only $25,47 \%$ of the population is digital included. This research is a case study done in a telecentre located in the East side of São Paulo and aimed to investigate whether telecentres could be considered a place of Social Education. The field work was carried out through a semi-structured questionnaire applied to a sample of 115 users of the telecentre. The analysis of the collected data indicated the existence of two different types of learning contents: computer science and social relations mediated by the computer or not. The obtained contents showed the specificity of the Education in the telecentre: the digital culture. Though it has been possible to verify advances in the use of technological resources, this study points to the necessity of a political and pedagogical project which has the intention to optimize the actions developed there. It demonstrates that the Education developed in the telecentre is not a nonformal practice because it is intentional and has a proper object.
\end{abstract}

Keywords: Digital Exclusion, Social Education, telecentre. 


\section{Lista de Ilustrações}

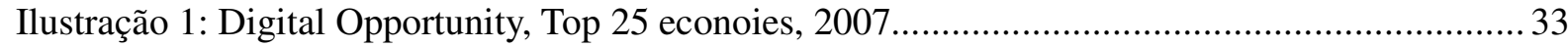

Ilustração 2: Ranking dos Incluídos Digitais - Municípios brasileiros (20 primeiros)................... 35

Ilustração 3: Ranking dos Incluídos Digitais - Municípios brasileiros (10 últimos). .................... 36

Ilustração 4: Total de PIDs apoiados pelos Programas/Projetos.................................................. 38

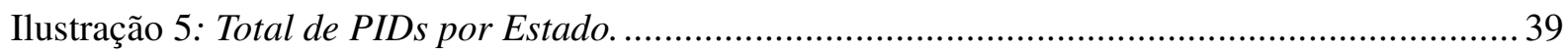

Ilustração 6: Unidades de atendimento do Programa Acessa São Paulo na Capital........................ 42

Ilustração 7: Distribuição dos telecentros na cidade de São Paulo............................................... 45

Ilustração 8: Mapa da Exclusão Social da Cidade de São Paulo................................................... 48

Ilustração 9: Unidades do Programa Casa Brasil na Cidade de São Paulo..................................... 49

Ilustração 10: Faixa Etária dos usuários de telecentro em São Paulo............................................ 53

Ilustração 11: O que o telecentro mudou na sua vida?............................................................... 54

Ilustração 12: Tipos de Comunicação X Linguagens Utilizadas................................................. 59

Ilustração 13: Características da Internet: tipos de comunicação, linguagens utilizadas e

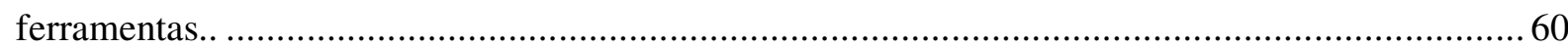

Ilustração 14: Indicadores do Distrito Cidade Tiradentes. ........................................................ 82

Ilustração 15: Sala do Tecno_Pombas. (Fotografia cedida pelo Instituto Pombas Urbanas, set/2007).

Ilustração 16: Usuários do acesso livre - Tecno_Pombas. (Fotografia cedida pelo Instituto Pombas

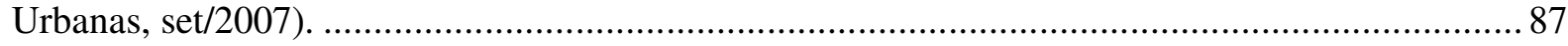

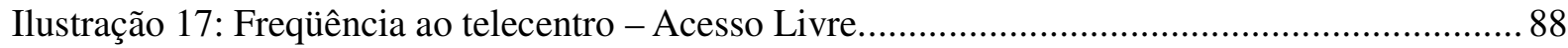

Ilustração 18: Utiliza o computador em outro lugar? ................................................................. 90

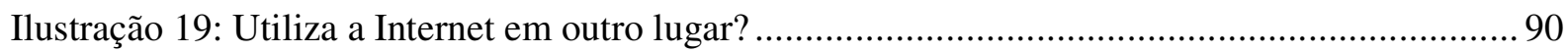

Ilustração 20: Onde utiliza o computador além do telecentro? .................................................. 91

Ilustração 21: Onde utiliza a Internet além do telecentro?......................................................... 91

Ilustração 22 - Coeficiente de Correlação …….................................................................. 96

Ilustração 23 - Utiliza o computador e a Internet na escola? ....................................................... 98

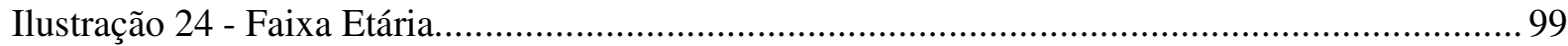

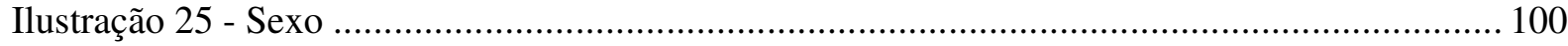

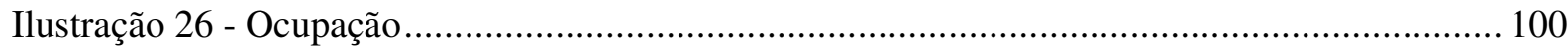

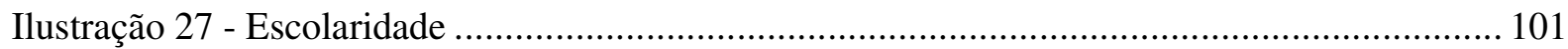

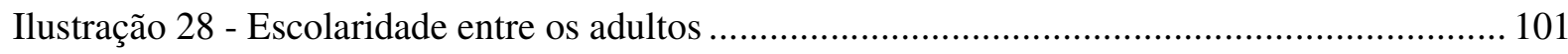




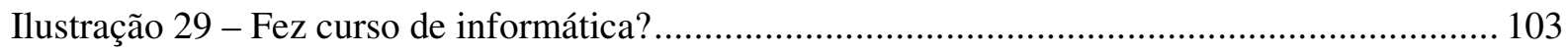

Ilustração 30 - Com quem você aprendeu a utilizar as ferramentas que utiliza no telecentro? ..... 108

Ilustração 31 - Intenção de uso e real utilização ..................................................................... 110

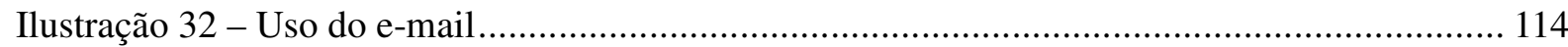

Ilustração 33 - Leitura de Notícias pela Internet..................................................................... 115

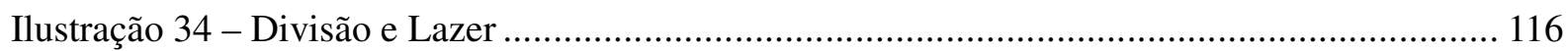

Ilustração 35 - Trabalhos escolares com os recursos do computador ...................................... 117

Ilustração 36 - Participação em comunidades on-line.............................................................. 119

Ilustração 37 - Participação em Fóruns de Discussão .............................................................. 119

Ilustração 38 - Serviços públicos .................................................................................. 121

Ilustração 39 - Procura por emprego na Internet................................................................... 123

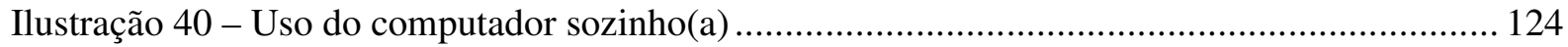




\section{Sumário}

Introdução 15

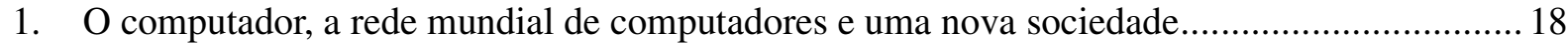

1.1. Tecnologias no tratamento da informação social ......................................................... 24

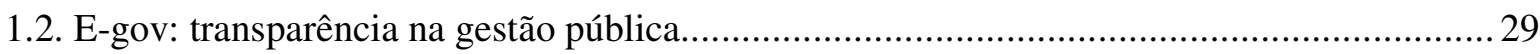

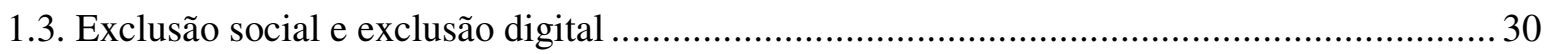

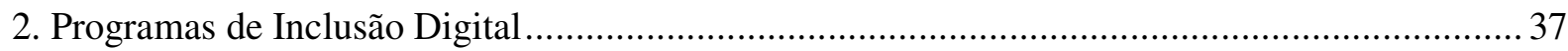

2.1. Programas de inclusão digital de iniciativa do governo federal........................................ 40

2.2. Programas de inclusão digital de iniciativa do governo estadual ...................................... 41

2.3. Programas de inclusão digital de iniciativa do governo municipal ................................... 43

2.4. Programas de inclusão digital de iniciativa da rede privada e do Terceiro Setor.................. 45

2.5. Programas de inclusão digital na cidade de São Paulo.................................................... 47

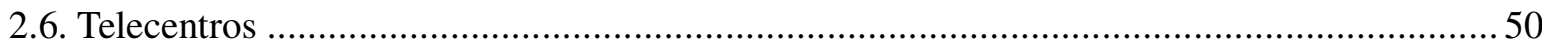

3. Cultura, Comunicação e Ensino na sociedade informacional .............................................. 55

3.1. Tecnologias como fonte de informação e Educação............................................................56

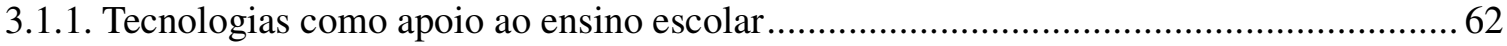

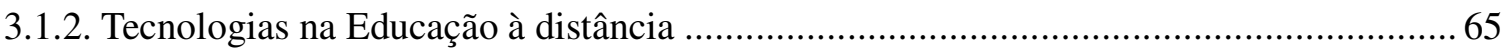

4. Podem os programas de Inclusão Digital serem espaços de educação? ................................... 70

4.1. Educação também se faz fora da escola: requalificando os espaços da cidade..................... 70

4.2. Educação Escolar e Educação Social ..................................................................... 72

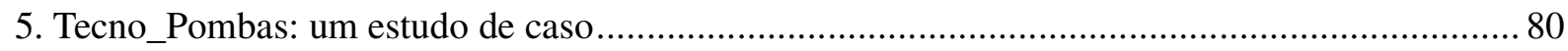

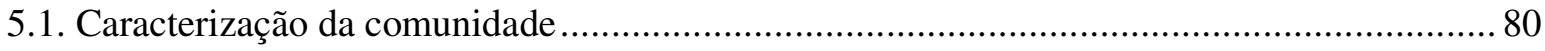

5.2. Caracterização da Instituição: o Instituto Pombas Urbanas................................................. 83

5.3. Caracterização do telecentro comunitário Tecno_Pombas ............................................. 84

5.4. Definição das fontes: levantamento bibliográfico, amostra e instrumentos para a coleta de

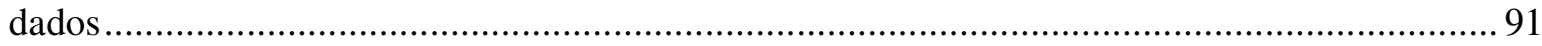

5.4.1. Caracterização do público atendido no telecentro ................................................... 97 


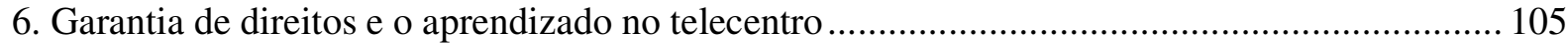

6.1. As relações sociais e a aprendizagem por meio da troca de informações........................... 106

6.2. Da intenção à real utilização: o que os usuários exploram no telecentro. .......................... 109

6.3. A relação entre frequiência de uso e os recursos disponibilizados no telecentro .................. 112

6.4. Cultura Digital: síntese dos conteúdos aprendidos no telecentro..................................... 124

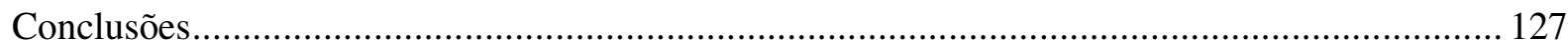

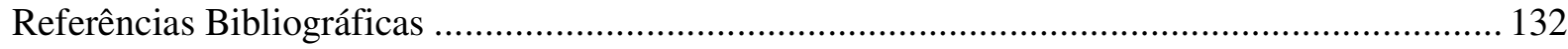

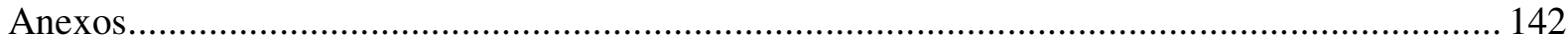




\title{
Introdução
}

\begin{abstract}
As tecnologias da informação, junto com a habilidade para usá-las e adaptá-las, são o fator crítico para gerar e possibilitar acesso à riqueza, poder e conhecimento no nosso tempo.
\end{abstract}

(Manuel Castells, 1999).

Atualmente, as tecnologias têm influenciado as relações sociais em todas as partes do mundo. Podemos visitar diversos lugares sem sair da sala de casa e conversar com parentes e amigos por diversos meios de comunicação tão rápidos e eficazes que nos dão a sensação de estar ao lado da outra pessoa.

Essas novas relações, decorrentes das transformações tecnológicas, têm levantado discussões sobre o surgimento de uma nova sociedade, em que a informação flui com velocidades e em quantidades há apenas poucos anos inimagináveis (TAKAHASHI, 2000, p. 03).

Novas maneiras de pensar e de conviver estão sendo elaboradas no mundo das telecomunicações e da informática. [...] Escrita, leitura, audição, criação, aprendizagem são capturados por uma informática cada vez mais avançada. (LÉVY, 1993, p. 07).

O nome dado às transformações em curso, advindos do desenvolvimento tecnológico, não é um termo consensual. Autores como Castells (1999), denominam este período como Era da Informação, já Silveira (2001) prefere o termo Revolução Informacional, mas o que há em comum em todas os nomes dados para este período é o fato de considerarem que, assim como as máquinas a vapor marcaram as indústrias têxteis no século XIX, a informação e seus mecanismos de transmissão e armazenamento, mediados pelo uso do computador, estão aumentando a capacidade de agir e de se comunicar dos indivíduos no nosso século.

Vivemos um desses raros intervalos na história. Um intervalo cuja característica é a transformação de nossa 'cultura material' pelos mecanismos de um novo paradigma tecnológico que se organiza em torno da tecnologia da informação (CASTELLS, 2006, p.67).

Independente do nome que os estudiosos dão às transformações tecnológicas do nosso tempo, é preciso considerar que a utilização das TICs (Tecnologias da Informação e da Comunicação) $^{1}$ têm definido fatores importantes de um novo modo de vida na sociedade e as

1 TIC (Tecnologia da Informação e da Comunicação) é, atualmente, o termo mais utilizado para definir uma "vasta gama de serviços, aplicações e tecnologias, utilizando vários tipos de hardware e software, servindo-se 
conseqüências dessa influência ainda estão sendo estudadas, uma vez em que estão em curso.

Trevisan (2005, p. 08) aponta que "análises preliminares indicam que as TICs possuem forte tendência a melhorar a qualidade de vida das comunidades onde estas estão sendo utilizadas", mas, apesar de reconhecer a existência desta "boa" influência das TICs na vida das pessoas que as utilizam, sabemos que muitos ainda não tem acesso às mesmas.

Ao mesmo tempo em que as tecnologias trazem avanços também proporcionam a emergência de uma nova forma de exclusão - a Exclusão Digital. Muitas vezes esse tipo de exclusão está ligado à exclusão social, com forte vínculo no valor da renda familiar. Isso porque o acesso às tecnologias ainda tem um custo muito alto para boa parte da população mundial.

O governo brasileiro e a sociedade civil têm organizado programas de inclusão digital para minimizar as diferenças causadas pela falta de acesso dos menos privilegiados aos meios digitais. $\mathrm{O}$ telecentro comunitário é um deles.

Esta pesquisa é um estudo de caso realizado em um telecentro da cidade de São Paulo - SP e tem como pressuposto que as tecnologias influenciam uma melhora na vida das pessoas e comunidades. Analisando o telecentro como um espaço educativo, pretende-se apresentá-lo como possibilidade de uma boa formação, diálogo com a realidade vivida e reflexões transformadoras nas comunidades menos privilegiadas.

A hipótese principal deste estudo é de que os telecentros funcionam não só como instrumentos de inclusão digital, uma vez que possibilitam acesso às TICs por parte das pessoas que não teriam acesso de outra forma, mas também como um espaço educativo que, embora não escolar, possibilita uma gama de aprendizagens aos seus usuários.

À luz dos estudos de Castells (2006) e Lévy (1993, 1996, 1999) sobre as transformações mediadas pelas novas tecnologias na nossa sociedade; de Silveira (2001) sobre a questão da exclusão/inclusão digital e de Silva, Clemente e Moura (2006, 2009) sobre os pressupostos da Pedagogia Social, este trabalho apresenta a educação no telecentro como uma prática existente e que possui objeto de estudo próprio: a aprendizagem da cultura digital.

Esse documento está organizado em seis capítulos seguidos das conclusões, sendo:

frequentemente das redes de telecomunicações. As TICs incluem serviços de telecomunicações bem conhecidos tais como a telefonia fixa, a telefonia móvel e o fax.[...] o correio eletrônico, a transferência de arquivos de um computador para outro e, sobretudo, a internet que potencialmente permite que todos os computadores estejam ligados entre si, fornecendo assim o acesso a fontes do conhecimento e de informação armazenadas nos sistemas informáticos de todo o mundo. As aplicações incluem a videoconferência, o teletrabalho, o ensino à distância, sistemas de gestão da informação, inventários; as tecnologias são múltiplas, desde as mais 'velhas' como o rádio e a televisão e as mais novas como as comunicações móveis celulares [...] A importância das TICs não consiste nas tecnologias como tal, mas no fato de que permitem acesso ao conhecimento, à informação e à comunicação: elementos cada vez mais importantes nas interações econômicas e sociais de hoje." (COMUNICAÇÃO DA COMISSÃO AO CONSELHO E AO PARLAMENTO EUROPEU, 2001, p. 3 apud TREVISAN, 2005, p. 08). 
Capítulo I - Contextualiza o universo da pesquisa, explorando o quadro teórico da Sociedade da Informação e o surgimento da Internet (rede mundial de computadores). O capítulo apresenta as tecnologias como um mecanismo capaz de promover a democratização da informação social e a transparência dos atos do governo (E-gov), mas reflete sobre as diferenças sociais resultantes da exclusão digital.

Capítulo II - Apresenta os principais projetos e programas federais, estaduais, municipais e locais concebidos por governos e sociedade civil para promover a inclusão digital. Dentre estes programas, o capítulo dá ênfase ao telecentro comunitário, objeto deste estudo de caso, como um programa de inclusão digital que permite acesso às TICs por parte das comunidades menos privilegiadas e dá um panorama de como este tipo de equipamento está implantado na cidade de São Paulo.

Capítulo III - Traz a reflexão sobre os usos das tecnologias na Educação, destacando as características da Internet como meio de comunicação e descrevendo alguns processos de utilização das tecnologias nas escolas e em projetos de Educação à distância.

Capítulo IV - Discute os conceitos de Educação Escolar e Educação Social, que serão utilizados na análise dos dados da pesquisa, apresentando a iniciativa do telecentro comunitário como um espaço de Educação Social.

Capítulo V - Descreve o trabalho desenvolvido no estudo de caso e contextualiza o objeto de estudo. Apresenta as características da comunidade (distrito de Cidade Tiradentes, zona Leste de São Paulo), do telecentro (Tecno_Pombas) e dos usuários pesquisados, justificando a importância da investigação do telecentro como espaço de Educação Social.

Capítulo VI - Apresenta os dados obtidos na pesquisa de campo sobre os conteúdos aprendidos e utilizados pelos usuários no telecentro, refletindo sobre o desenvolvimento de habilidades para a utilização dos recursos digitais.

Conclusões - Apresenta as conclusões da análise teórica atrelada aos resultados obtidos na pesquisa de campo. Situa a prática de Educação dos telecentros comunitários na área de Educação Social, identificando um conteúdo específico nesse tipo de abordagem - a educação da cultura digital. 


\section{O computador, a rede mundial de computadores e uma nova sociedade}

Talvez escutando as coisas, os sonhos que as precedem, os delicados mecanismos que as animam, as utopias que elas trazem atrás de si, possamos aproximar-nos ao mesmo tempo dos seres que as produzem, usam e trocam, tecendo assim o coletivo misto, impuro, sujeito-objeto que forma o meio e a condição de possibilidade de toda comunicação e todo o pensamento. (LÉVY, 1993, p. 11).

A história das grandes civilizações é marcada por descobertas e criações nos diferentes tempos e lugares. Refletir sobre o surgimento de uma nova tecnologia é compreender melhor seu processo gerador e, portanto conhecer seu lugar de origem e seus criadores. Cada inovação tecnológica tem por princípio uma necessidade social e pode ser entendida como extensão da mente humana.

\footnotetext{
computadores, sistemas de comunicação, decodificação e programação genética são todos amplificadores e extensões da mente humana. $\mathrm{O}$ que pensamos e como pensamos é expresso em bens, serviços, produção material e intelectual, sejam alimentos, moradia, sistemas de transporte e comunicação, mísseis, saúde, educação ou imagens. (CASTELLS, 1999a, p. 69).
}

Antes mesmo de se tornarem reais, os meios tecnológicos surgem nas mentes humanas em resposta às necessidades dos grupos sociais e consideram, essencialmente, o processo produtivo da humanidade.

Os períodos de grandes mudanças nas atividades produtivas no mundo foram classificados e estudados pelos historiadores como Revolução Industrial. A primeira revolução, que ocorreu no século XVIII, induziu um padrão de descontinuidade nas bases materiais da economia, sociedade e cultura (idem, p.68). Já a Segunda Revolução Industrial, nos últimos anos do século XIX, foi marcada pelo uso intensivo de novas fontes de energia, o que permitiu a criação e o desenvolvimento de novas máquinas, modificando-se os processos de produção da indústria.

Hoje, vivemos em um período histórico com o desenvolvimento crescente de novos meios tecnológicos que além de modificarem as relações produtivas na indústria, têm influenciado o modo de vida das pessoas, trazendo novas configurações de relações sociais. Este novo processo da história, se pode ser chamado de uma nova revolução, diferente das revoluções anteriores, é marcada pelas tecnologias da informação e da comunicação. 
o cerne da transformação que estamos vivendo na revolução atual refere-se às tecnologias da informação, processamento $e$ comunicação. A tecnologia da comunicação é para esta revolução o que as novas fontes de energia foram para as revoluções industriais sucessivas, do motor a vapor à eletricidade, aos combustíveis fósseis e até mesmo à energia nuclear. (idem, p.68, grifo do autor).

Em qualquer tempo e lugar, a influência de uma nova tecnologia na sociedade passa a ser percebida na medida em que as pessoas se apropriam dela, utilizando-a nas suas relações e necessidades cotidianas.

Atualmente, apesar de percebermos que a apropriação das tecnologias da informação e comunicação por parte das pessoas tem ocorrido de forma bastante veloz, não podemos afirmar categoricamente que as revoluções tecnológicas determinam as relações econômicas, sociais e políticas da sociedade.

Diferente das abordagens de exagero profético ${ }^{2}$ com relação à revolução informacional, é importante destacar a afirmação de Lévy (1999) que, ao estudarmos qualquer atividade humana, estamos necessariamente abrangendo: pessoas vivas e pensantes; entidades materiais naturais e artificiais; idéias e representações (LÉVY, 1999, p. 22).

Essa consideração aponta para o fato de que não podemos separar o ser humano de seu ambiente material e, por isso, assim como Castells (1999a), Silveira (2001) e o próprio Lévy (1993), pretendo estudar a revolução tecnológica sob uma perspectiva mais ampliada: ao mesmo tempo em que as sociedades sofrem influências dos novos meios tecnológicos, o uso que as pessoas fazem deles também os modificam. É uma espécie de ciclo, onde a criação e re-criação são processos contínuos.

redes interativas de computadores estão crescendo exponencialmente, criando novas formas e canais de comunicação, moldando a vida e, ao mesmo tempo, sendo moldadas por ela. (CASTELLS, 1999a, p. 40).

O ser humano é criador, desenvolvedor e usuário das tecnologias ao mesmo tempo em que têm suas vidas e relações modificadas por elas. Para Castells, nem uma relação nem outra é determinada: tanto a sociedade como as inovações tecnológicas não são estabelecidas nem estabelecem normas, elas estão em processo de incorporação e utilização "A tecnologia não

2 Manuel Castells, no capítulo 1, do livro A sociedade em Rede, faz uma explicação do desenvolvimento das tecnologias por meio de um minucioso levantamento histórico das revoluções industriais e dos principais eixos da transformação tecnológica. Ele aponta que "o exagero profético e a manipulação ideológica que caracteriza a maior parte dos discursos sobre a revolução tecnológica da informação não deveria levar-nos a cometer o erro de subestimar sua importância verdadeiramente fundamental". 
determina a sociedade: incorpora-a. Mas a sociedade também não determina a inovação tecnológica: utiliza-a" (idem, p. 62).

Lévy (1999) também considera esta abordagem e pontua que "em vez de enfatizar o impacto das tecnologias, poderíamos igualmente pensar que as tecnologias são produtos de uma sociedade e de uma cultura”. (LÉVY, 1999, p.22) e, portanto, o processo de desenvolvimento não é somente um processo técnico ou somente cultural, mas um conjunto de relações humanas que precisam ser estudadas e entendidas.

\begin{abstract}
As verdadeiras relações, portanto, não são criadas entre "a" tecnologia (que seria da ordem da causa) e "a" cultura (que sofreria os efeitos), mas sim entre um grande número de atores humanos que inventam, produzem, utilizam e interpretam de diferentes formas as técnicas. (LÉVY, 1999, p.23).
\end{abstract}

Nesta perspectiva, pretendo estudar as tecnologias e seus impactos na sociedade com o foco nas relações humanas, destacando suas utilizações nas relações sociais, principalmente na Educação.

Assim, é importante entender o computador como a principal ferramenta tecnológica da atualidade, uma vez que está incorporando as relações sociais ao mesmo tempo em que vem sendo utilizado por e para elas.

Ainda com particularidades diferentes das que conhecemos hoje, ele surgiu, no início do século XX, para atender às necessidades da indústria bélica americana e hoje é o principal meio de comunicação e organização da informação dentre as TICs no nosso tempo.

Na sua origem, o computador não era interativo com o usuário. Foi por meio da curiosidade de um grupos de jovens estudantes que, progressivamente, o computador pessoal foi sendo construído: interface por interface (LÉVY, 1993, p.45). O surgimento do Apple Macintoshi, em 1984, foi um marco neste processo de desenvolvimento, uma vez que suas interfaces apresentavam dois elementos importantes: ícones e mouse, que facilitavam a interatividade entre usuário e máquina.

Desde então, as empresas de informática passaram a desenvolver novos e variados recursos, adaptando as interfaces de forma que elas pudessem responder às necessidades de uma empresa, de um grupo de pessoas e de uso pessoal. Esse movimento abriu possibilidades de "novas relações entre homens e computadores: códigos de programação cada vez mais intuitivos, comunicação em tempo real, redes, micro, novos princípios de interfaces". (idem, p. 54).

O desenvolvimento das interfaces amigáveis $^{3}$ permitiu a ampliação do número de usuários

3 O termo é utilizado para expressar a aproximação das interfaces digitais à linguagem dos usuários. Quanto mais 
por todo o mundo e em todos os setores já que elas possibilitam a qualquer pessoa, ainda que não conheça linguagem de programação ou não entenda sobre o funcionamento da máquina, utilizar as funções do computador para o trabalho e também para interesses pessoais. Dessa forma, podemos afirmar que cada inovação na informática contribuiu para a expansão do uso deste equipamento, o que fez com que, em um espaço de tempo de apenas uma geração, o homem passasse a compartilhar um novo mundo repleto de computadores e máquinas (TENÓRIO, 2003, p. 19).

Tornando-se uma máquina interativa com o usuário, o computador passou a ser essencialmente ferramenta de tratamento da informação e, porque otimiza o tempo e facilita a organização e armazenamento de dados, transforma os ritmos e modalidades da comunicação e contribui para a redefinição de organizações, tempos e espaços.

Os impactos causados pelo computador na sociedade estão presentes nos debates contemporâneos, mas não foram totalmente analisados, uma vez que o processo de desenvolvimento tecnológico iniciado a partir dele ainda está em curso. Alguns pesquisadores como Takahashi (2000, p. 3), tecem hipóteses de análise para a nova revolução. Ele destaca três processos que nos permitem compreender melhor as transformações geradas a partir da utilização e incorporação do computador pelas pessoas no cotidiano:

I - a convergência de conteúdos, computação e comunicações (que gera diversos e novos meios de comunicação, demandando às pessoas uma capacidade de absorção dos mesmos);

II - dinâmica da indústria (popularização crescente das máquinas que está cada vez mais acelerada, dado o aumento da produção e dos custos reduzidos: o que antes era privilégio de acadêmicos ou grandes empresas, hoje é encontrado em domicílios e até como um instrumento portátil e pessoal);

\section{III - crescimento da Internet.}

O primeiro processo apontado por Takahashi ressalta o potencial do computador como um meio que converge múltiplos conteúdos, o que facilita a organização de dados e potencializa a produção humana. Porém, ao mesmo tempo em que estes conteúdos estão sendo disponibilizados para a população, exige-se que ela saiba utilizá-los e, dessa forma, é possível afirmar que o computador introduziu uma nova racionalidade nas relações entre Estado/indivíduo,

amigável, mas facilidade o usuário encontrará em utilizá-la. Lévy (1993, p. 52) nomeia este processo de construção de interfaces de "humanização das máquinas", ou seja, "essas interfaces, essas camadas técnicas suplementares tornam os complexos agenciamentos de tecnologias intelectuais e mídias de comunicação, também chamados de sistemas informáticos, mais amáveis e mais imbricados ao sistema cognitivo humano". 
Estado/sociedade, capital/trabalho e nas relações humanas e sociais. Considerando a afirmação de Marcuse de que

\begin{abstract}
Hoje, a dominação eterniza-se não só mediante a tecnologia, mas como tecnologia; e esta proporciona a grande legitimação ao poder político expansivo, que assume em si todas as esferas da cultura. Neste universo, a tecnologia proporciona igualmente a grande racionalização da falta de liberdade do homem e demonstra a impossibilidade 'técnica' de ser autônomo, de determinar pessoalmente a sua vida (MARCUSE, apud. SILVEIRA, 2004, p. $05)$.
\end{abstract}

Em uma sociedade cada vez mais marcada pelo uso da tecnologia, as relações entre governo, população e grupos sociais são alteradas porque, ao mesmo tempo em que a produção e difusão da informação são compartilhadas na rede, a liberdade de uso está limitada pela falta de acesso e, muitas vezes, pela falta de conhecimento. A partir desta afirmação de Marcuse, é possível pensar em algumas questões: a quem interessa o domínio e utilização das tecnologias? Quem detém a informação na sociedade tecnológica?

O segundo ponto levantado por Takahashi (dinâmica da indústria) amplia essas reflexões uma vez que, a produção das tecnologias está cada vez mais acelerada e não é fácil identificar se são as relações de mercado que impõem o desejo de aquisição dos equipamentos tecnológicos às pessoas ou se as pessoas necessitam deles para estar inseridas na sociedade. A dependência dos meios tecnológicos é verdadeira ou é uma imposição da indústria?

Acredito que essa pesquisa não dará conta de responder a perguntas desta natureza de forma conclusiva, mas considero necessário apontar que existem muitos processos em curso na revolução tecnológica informacional que estão no âmbito não só da própria tecnologia, mas da política, da indústria, do mercado, da educação etc. Nessa perspectiva, apresento a hipótese do surgimento da Internet como um elemento marcante em todos esses setores.

O desenvolvimento da Internet, Rede Mundial de Computadores, foi o fator decisivo para a entrada do computador no meio das comunicações. Segundo Trevisan (2005, p. 16), somente com a popularização da rede, os computadores passaram a ser utilizados para a comunicação em diferentes esferas, sendo visto inclusive como um meio de obter empregos e ascender socialmente.

Brarda e Rios (2004, p. 18) também identificam que a rede mundial de computadores desenvolveu novas formas de relações pessoais, econômicas, comerciais etc. Afirmam também que o surgimento e o crescimento da Internet possibilitaram outra combinação entre Economia e desterritorialização de atividades.

A origem da Internet ocorre em 1969, quando a Advanced Research Projects Agency 
(ARPA), do Departamento de Defesa dos Estados Unidos iniciou o projeto de uma rede que deu origem à ARPANet. Era uma rede interna, de motivação militar, que tinha, como um dos seus objetivos, recuperar a vanguarda tecnológica norte-americana. (SILVEIRA, 2001, p. 12).

\begin{abstract}
Era o auge da Guerra Fria e a demanda era criar um sistema de interconexões entre computadores de qualquer tipo que pudesse manter-se em operação com redundância de armazenagem de dados e de processamento mesmo que vários de nós fossem destruídos. (AFONSO, 2000, p. 4).
\end{abstract}

Deste projeto inicial surgiram outras redes de comunicação por meio de computadores. Eram redes comerciais ou cooperativas que utilizavam protocolos próprios e por isso não estavam interligadas. No final da década de 80 alguns milhares de usuários de computadores já faziam uso desse tipo de comunicação por todo o mundo, mas somente na década de 90 do século XX, é que essas redes foram interligadas com o surgimento e expansão da Internet.

A criação da World Wide Web ${ }^{4}$ (WWW), neste período, foi um salto tecnológico decisivo, pois, segundo Castells (1999a, p. 86), foi ela que possibilitou a organização dos sítios da Internet por informação e não por localização, oferecendo aos usuários um sistema mais fácil para pesquisas e busca de informações desejadas.

A invenção da $W W W$ se deu na Europa, no Centre Européen poour Recherche Nucleaire (CERN). O grupo de estudiosos do CERN não realizou sua pesquisa segundo a tradição da ARPANET, "mas com a contribuição da cultura dos hackers da década de 1970" (idem, p. 88). O trabalho destes pesquisadores resultou num novo formato de documentos que nomearam como Linguagem de Marcação de Hipertexto (Hypertex markup language - HTML) e foi essa linguagem a principal difusora do uso da Internet por todo o mundo, transformando-a na espinha dorsal da comunicação global mediada pelo computador.

É difícil precisar o número de usuários da Internet espalhados pelo mundo, porém, segundo Trevisan (2005, p. 17), tudo indica que ele aumenta a cada dia e que a Internet está cada vez mais popular. A pesquisa de uma empresa americana, em 2005, estimava que os usuários da rede mundial de computadores no mundo passava de um bilhão ${ }^{5}$.

A Internet chegou ao Brasil no início da década de 1990 com objetivos acadêmicos e com apoio das agências Fapesp, Faperj e $\mathrm{CNPq}^{6}$. Inicialmente, somente as Universidades tinham acesso

4 Em português, Rede Mundial de Computadores.

5 eMarketer, pesquisa Worldwide Online Access: $2004 \quad$ - 2010, disponível em http://www.emarketer.com/Report.aspx?code=bband_world_jun06.

6 Fapesp (Fundação de Amparo à Pesquisa do Estado de São Paulo); Faperj (Fundação de Amparo à Pesquisa do Estado do Rio de Janeiro); CNPq (Conselho Nacional de Desenvolvimento Científico e Tecnológico). 
à rede, porém com apoio do Ministério das Comunicações e do Ministério da Ciência e Tecnologia, a Internet foi, aos poucos, entrando em outros setores como a comunicação, o comércio, a Educação etc.

Em 1995, uma Portaria Interministerial criou o Comitê Gestor da Internet no Brasil (CGI) para coordenar e integrar as iniciativas e serviços da Internet no país. Os dados mais recentes levantados por este órgão são da Pesquisa sobre o Uso das TICs no Brasil - 2007 (BALBON, 2008), divulgados no início de 2008. Segundo eles, pela primeira vez desde que a pesquisa é realizada, mais da metade (53\%) dos entrevistados informou já ter usado o computador alguma vez e o número de internautas chegou a $34 \%$ da população, o que corresponde a um aumento de seis pontos percentuais em relação ao ano anterior.

Os dados apresentados pelo CGI mostram que o número de internautas no Brasil está crescendo a cada dia. Isso porque, em diversas áreas, os serviços oferecidos na e pela rede estão se aprimorando $^{7}$ : as relações pessoais, de trabalho e de serviços estão se alterando na medida em que a Internet passa a ser a principal ferramenta de comunicação do nosso tempo.

\subsection{Tecnologias no tratamento da informação social}

A partir da década de 90 do Século XX, com o surgimento das redes de computadores, cresce a utilização dos recursos de TIC para a produção de informações de natureza social no sentido de orientar tanto governos quanto a sociedade civil na elaboração de políticas e de ações para enfrentamento da pobreza e da desigualdade social.

Historicamente, a produção e a gestão da informação têm sido orientadas, predominantemente, para o controle social por parte do Estado em relação aos seus cidadãos. Estudiosos como Foucault (Microfísica do poder, 1979), Durkheim (As regras do método sociológico, 1895) e Goffman (Estigma: Notas Sobre a Manipulação da Identidade Deteriorada, 1988) indicaram, em suas obras, como são os mecanismos de controle do poder e da informação,

7 Outros dados da pesquisa do CGI (BALBON, 2008) nos permitem observar isso: 23\% dos Internautas já fizeram alguma compra pela internet (PROPORÇÃO DE INDIVÍDUOS QUE COMPRARAM PRODUTOS E SERVIÇOS PELA INTERNET, p.200); 40\% dos entrevistados possuem telefones celulares com acesso à Internet (PROPORÇÃO DE INDIVÍDUOS QUE POSSUEM TELEFONE CELULAR COM ACESSO à INTERNET, p.220); 95\% das empresas entrevistadas usam computadores para desenvolver seus trabalhos (PROPORÇÃO DE EMPRESAS QUE USAM COMPUTADORES, p. 227); 54\% dos funcionários dessas empresas usam o computador (PROPORÇÃO DE FUNCIONáRIOS QUE USAM COMPUTADORES, p. 229) e 17\% das empresas entrevistadas declaram que já substituíram completamente o correio postal por meios eletrônicos (GRAU DE SUBSTITUIÇÃO DO CORREIO POSTAL POR MEIOS ELETRÔNICOS DE COMUNICAÇÃO, p.235). 
capazes de reafirmar a dependência dos indivíduos em relação às estruturas sociais estabelecidas. Uma obra literária que ilustra bem estas teorias é 1984, de George Orwell (1949).

\begin{abstract}
o livro conta a história de Winston Smith, membro do partido externo, funcionário do Ministério da Verdade. A função de Winston é reescrever e alterar dados de acordo com o interesse do Partido. Nada muito diferente de um jornalista ou um historiador. Winston questiona a opressão que o Partido exercia nos cidadãos. Se alguém pensasse diferente, cometia crimidéia (crime de idéia em novilíngua) e fatalmente seria capturado pela Polícia do Pensamento e era vaporizado. Desaparecia. (DUPLIPENSAR, 2004).
\end{abstract}

A obra é inspirada nos regimes totalitários das décadas de 30 e 40 (nazismo, stalinismo) e critica não só os grandes estados desta natureza como também "a nivelação da sociedade e a redução do indivíduo em peça para servir ao estado ou ao mercado" (idem). Apesar de se tratar de um romance literário, o livro traz em seu enredo alguns questionamentos pertinentes ao nosso tempo.

Considerando que toda informação, veiculada para a população, é política e intencional, capaz de formar opinião e moldar as percepções dos cidadãos quanto a sua identidade e condição social, é preciso pensar no papel das tecnologias no nosso tempo: elas se apresentam como reforço ou mecanismo de transformação desse processo de dominação por meio da informação?

Marcuse (1964) afirmava que "tecnologia serve para instituir formas novas, mais eficazes e mais agradáveis de controle social” (MARCUSE, 1964, p. 18). Para o autor, os novos meios tecnológicos atuam como mantenedores de interesses da sociedade industrial.

Como os grandes regimes totalitários mundiais mostraram ao longo da história, a afirmação de Marcuse não é totalmente falsa, mas é importante considerar que, ao mesmo tempo em que as tecnologias se colocam como reprodutoras das estruturas já existentes, elas podem instituir novas formas de veiculação da informação e por isso, torna-se necessário resgatar o sentido do termo informação social.

Goffman apresenta o conceito de informação social como "a informação que o indivíduo transmite diretamente sobre si." (GOFFMAN, 1988, p. 08). Hoje, o conceito não deixa de considerar esta primeira definição, mas é utilizado de forma mais ampliada.

A informação sobre a pobreza é uma parte e, de certo modo, também o centro da informação social. Esta desenvolveu-se na Alemanha especialmente a partir das iniciativas da informação sobre a pobreza, logo foi originada da necessidade de esclarecer e melhorar as condições de vida dos socialmente mais injustiçados, 
dos grupos sociais inferiores. (FERCHLAND, REIMANN ${ }^{8}$ ).

O termo informação social tem sido utilizado para caracterizar as informações sobre as classes sociais menos privilegiadas, apresentando seu real quadro de necessidades e opressão. Este tipo de informação visa, como na afirmação de Goffman, fazer um retrato da condição que essas classes têm de si e não como uma informação que lhes fora imposta, sem qualquer questionamento sobre sua veracidade.

O conceito de informação social possibilitou a criação dos chamados índices sociais que geralmente se tratam de grandes bases de dados submetidas a processamento estatístico e a técnicas de georeferenciamento para identificação dos principais problemas que afetam determinadas populações.

A intenção de mapear as informações sociais tem como propósito não só romper com os processos de domínio da informação e condição de cegueira dos oprimidos, mas também atuar como indicador para elaboração de políticas públicas na superação das condições de exclusão social.

Abaixo são apresentados alguns exemplos de indicadores que se utilizam do conceito de informação social não mais para o controle social ou para subsidiar projetos político-ideológicos de grupos no poder, mas sim para transformar realidades e elevar a qualidade de vida da população.

$\mathrm{O}$ IDH (Índice de Desenvolvimento Humano) acompanhado pelo Relatório de Desenvolvimento Humano (RDH) publicado anualmente pelo PNUD (Programa das Nações Unidas para o Desenvolvimento) utiliza-se de uma grande base de dados que pretende reforçar a relevância de dados sociais, culturais e políticos além dos econômicos para avaliar as condições de vida em todo o mundo. Desde 1990, os RDHs apresentam uma agenda sobre temas relevantes ligados ao desenvolvimento humano e reúnem tabelas estatísticas e informações sobre o assunto. Esse tipo de estudo é resultado da elaboração de tecnologias apropriadas para o tratamento da informação social.

O objetivo da elaboração do Índice de Desenvolvimento Humano é oferecer um contraponto a outro indicador muito utilizado, o Produto Interno Bruto (PIB) per capita, que considera apenas a dimensão econômica do desenvolvimento. [...] Aos poucos, o IDH tornou-se referência mundial. É um índice-chave dos Objetivos de Desenvolvimento do Milênio das Nações Unidas e, no Brasil, tem sido utilizado pelo governo federal para eleboração do Índice de Desenvolvimento Humano Municipal (IDH-M), que pode ser consultado no Atlas do Desenvolvimento Humano no Brasil, um banco de dados eletrônico com informações sócio-econômicas

8 http://www.rls.org.br/publique/media/Ferchland_Reimann.pdf 
sobre os 5.507 municípios do país, os 26 Estados e o Distrito Federal. $^{9}$

Outro exemplo da utilização da tecnologia para o tratamento da informação social é o estudo realizado pela Prefeitura da cidade de São Paulo, em parceria com a PUC/SP e Instituto Pólis, intitulado Mapa da Exclusão Social (2000). Muito semelhante ao IDH, que reúne dados sociais além dos dados econômicos, o Mapa da Exclusão Social buscou

constatar através de 49 indicadores analisados dentre os 96 distritos da cidade de São Paulo, o máximo de inclusão e o máximo de exclusão registrados e expressos como a melhor e a pior situação detectada na população de um distrito da cidade. (SPOSATI, 2000).

Este estudo foi possível por meio do cruzamento de índices isolados como escolaridade, expectativa de vida da população, taxa de natalidade/mortalidade etc e permitiu a criação do Índice de Exclusão Social (Iex). Este índice faz parte das estratégias de implantação da Lei Orgânica da Assistência Social (LOAS) que, em dezembro de 1993, estabeleceu que cabe a essa política social a responsabilidade pela provisão de mínimos sociais à sociedade brasileira, porém, saber o que são os mínimos sociais necessários, só foi possível mediante a um estudo e análise de índices reais (informação social), o que mostra a importância deste tipo de estudo e utilização da tecnologia para a sociedade.

Devido a essa importância e utilizando-se dos estudos anteriores como referência, no mesmo ano (2000), a Fundação Sistema Estadual de Análise de Dados (Seade), criou o Índice Paulista de Responsabilidade Social (IPRV) que permitiu

\footnotetext{
a construção de indicadores que expressassem o grau de desenvolvimento social e econômico dos 645 municípios do Estado de São Paulo. A partir desse sistema de indicadores, a Assembléia Legislativa passou a dispor de novos subsídios para a reflexão a respeito dos elementos que induzem diferentes desempenhos econômicos e sociais dos municípios paulistas. ${ }^{10}$
}

Apesar de apresentar dados sobre o desenvolvimento dos municípios paulistas, o IPRS não respondeu integralmente às questões da eqüidade e da pobreza existentes no interior dessas localidades, e então, partindo da compreensão de que a vulnerabilidade social decorre de fenômenos diversos, com causas e conseqüências distintas, a Fundação Seade buscou outras bases de dados e

\footnotetext{
9 http://www.pnud.org.br/idh/

10 http://www.al.sp.gov.br/web/ipvs/index_ipvs.htm
} 
processos de georeferenciamento na tentativa de localizar as particularidades de cada ponto dos municípios.

Foi então criado o Índice Paulista de Vulnerabilidade Social (IPVS), que permite tanto aos gestores públicos como à sociedade uma visão mais detalhada do quadro social das localizações de seu município, facilitando a implantação e avaliação das políticas públicas locais. Este índice fez uso dos dados do Censo Demográfico de 2000 e permitiu a representação de 48 mil setores censitários do Estado de São Paulo.

Por fim, é possível ainda citar o Índice de Vulnerabilidade Juvenil (IVJ), 2002 ${ }^{11}$, como outro estudo que fez uso de tecnologias para o tratamento da informação social. Também concebido pela Fundação Seade, o IVJ tinha como objetivo criar uma base de informações locais específicas sobre os jovens a fim de se propor políticas e projetos culturais, educacionais e de promoção social a este segmento da sociedade paulista.

O IVJ foi o principal indicador para o projeto Fábricas de Cultura, da Secretaria Estadual de Cultura no ano de 2004 e tem sido utilizado até hoje na elaboração de iniciativas públicas e privadas.

\footnotetext{
o indicador passou a ser de domínio público e tornou-se referência para ações públicas e privadas que tivessem como horizonte promover um crescente processo de pacificação e resgate da autoestima de adolescentes e jovens. (SEADE, 2002).
}

Os estudos citados mostram que a informação social, quando explícita à população, permite que todos, gestores e sociedade, possam elaborar programas e políticas públicas que visam à melhoria da qualidade de vida da população menos privilegiada.

As tecnologias têm um papel importante neste cenário, possibilitando maior transparência dos dados à população. É preciso, contudo, lembrar que este tipo de leitura ainda não é comum nem fácil de ser realizada. De nada adianta a demonstração de dados se não existem pessoas que possam interpretá-los. De nada adianta disponibilizar os dados à população se ela não souber suas finalidades. Se não houver uma comunicação eficaz entre a informação social veiculada e a população a qual ela se refere, as tecnologias de tratamento da informação serão apenas mais uma forma de dominação: "uma sociedade avançada que transforma o progresso científico e técnico em instrumento de dominação”. (MARCUSE, 1964, p. 35).

11 http://www.seade.sp.gov.br/produtos/ivj/ivj_2000_05.pdf 


\title{
1.2. E-gov: transparência na gestão pública
}

uma vez que a internet está se tornando um meio essencial de comunicação e organização em todas as esferas de atividade, é obvio que também os movimentos sociais e o processo político a usam, e o farão cada vez mais, como um instrumento privilegiado para atuar, informar, recrutar, organizar, dominar e contradominar. (CASTELLS, 2003 apud. TREVISAN, 2005, p. 34).

Diversos governos democráticos têm procurado, por meio da Internet, fortalecer sua legitimidade pela criação de novos canais de participação do cidadão. Segundo Trevisan (2005),

\begin{abstract}
Estes canais permitem o acesso a serviços públicos informatizados, entre eles solicitações de determinados documentos, disponibilização de informações gerais e específicas sobre a administração pública, além da possibilidade de interlocução direta, menos burocratizada, entre o poder público e o cidadão. (idem).
\end{abstract}

Este tipo de comunicação e serviço representa uma economia de recursos por parte do governo e pode possibilitar o acesso da população aos processos governamentais, permitindo aos cidadãos acompanhar, por exemplo, a aplicação do orçamento previsto para seu município, estado ou país.

\begin{abstract}
A divulgação e o uso de novos conhecimentos e tecnologias podem fortalecer o processo democrático, bem como possibilitar à sociedade encontrar novas formas de convivência e de superação dos desníveis existentes. (SILVEIRA,H.F.R. 2001)
\end{abstract}

A possibilidade de tornar os processos mais democráticos no país e otimizar recursos e serviços prestados à população com o apoio da comunicação mediada pela Internet, em 1994, o governo federal, por meio da Portaria SAF n. 3.094 (de 10 de outubro de 1994), criou o Programa de Normalização Técnica para Informática Pública (Nortec). Segundo Simão e Rodrigues (2005),

\begin{abstract}
seu objetivo era estudar e propor normas, procedimentos, padrões, especificações e orientações técnico-administrativas para promover a utilização racional dos recursos de informática e a integração dos sistemas de tratamento da informação no âmbito da administração pública federal direta, autárquica e fundacional. (SIMÃO, RODRIGUES, 2005)
\end{abstract}

Este programa deu origem ao Portal Rede Governo ${ }^{12}$ que surgiu no ano seguinte, "como uma solução para viabilizar uma estrutura cooperativa de trabalho, cujas características técnicas e operacionais permitissem e assegurassem intercomunicação e interoperação aos ambientes já instalados" (ARAÚJO, 2001 op. cit. SIMÃO, ROFRIGUES, 2005). Era o início do projeto de uma

12 http://www.e.gov.br 
infra-estrutura de comunicação e serviços do governo brasileiro com a sociedade.

Em 3 de abril de 2000, o então presidente da República Fernando Henrique Cardoso assinou o decreto presidencial que criou o Grupo Interministerial de Trabalho em Tecnologia da Informação, formalizado pela Portaria da Casa Civil no 23 de 12 de maio de 2000. O grupo de trabalho tinha como objetivo examinar e propor políticas e diretrizes relacionadas às novas tecnologias de informação e comunicação para o país.

Após estudos e relatórios preliminares, em outubro de 2000, foi estabelecido o Comitê Executivo de Governo Eletrônico (E-gov), dando início ao desenvolvimento de uma série de serviços governamentais prestados por meios digitais.

Segundo o Portal do Governo Eletrônico ${ }^{13}$, a política desenvolvida por estes serviços atua em três frentes: junto ao cidadão; na melhoria da sua própria gestão interna e na integração com parceiros e fornecedores.

\begin{abstract}
O que se pretende com o Programa de Governo Eletrônico brasileiro é a transformação das relações do Governo com os cidadãos, empresas e também entre os órgãos do próprio governo de forma a aprimorar a qualidade dos serviços prestados; promover a interação com empresas e indústrias; e fortalecer a participação cidadã por meio do acesso a informação e a uma administração mais eficiente. ${ }^{14}$
\end{abstract}

A utilização das tecnologias por parte do governo é um importante meio para a democratização da informação e possibilita maior participação social nas questões públicas, porém, é preciso considerar que nem todas as pessoas têm acesso aos meios tecnológicos utilizados pelo governo e, infelizmente, ainda que muitos recursos sejam investidos para a implantação do E-gov, boa parte da população acaba se distanciando ainda mais da possibilidade de utilizar os serviços prestados.

\title{
1.3. Exclusão social e exclusão digital
}

Como já abordado no início deste capítulo, o computador e a Internet têm entrado no cotidiano da vida das pessoas e instituições, sendo essenciais nas relações comerciais, econômicas, políticas e educativas na atualidade. Porém, se por um lado a sociedade tem se desenvolvido no que diz respeito à utilização dos meios tecnológicos, por outro, esses mesmos meios podem ser os responsáveis por um distanciamento entre as classes sociais.

13 http://www.governoeletronico.gov.br/o-gov.br

14 idem 
Rodrigo Baggio (2000), fundador e diretor do Comitê para a Democratização da Informática (CDI), afirma que “o abismo que separa os ricos dos pobres” se dá pelo não compartilhamento do conhecimento acumulado pela sociedade. Para Baggio, o analfabetismo digital pode significar uma exclusão social.

O termo exclusão era utilizado no Brasil para caracterizar a "posição de determinados segmentos da sociedade em relação aos direitos coletivos e sociais" (SILVEIRA, 2008) e está sendo utilizado na esfera digital em substituição aos termos digital divide, digital apartheid, divisão ou brecha digital.

Lévy (1999) afirma que "Cada novo sistema de comunicação fabrica os seus excluídos. Não havia iletrados antes da invenção da escrita" (LÉVY, 1999, p. 237). Apesar de reconhecer como verdadeira a afirmativa de Lévy, devo concordar com Silveira (2008) que aceitá-la como natural, pode minimizar o debate sobre o tema da exclusão digital.

No Brasil, os índices de exclusão digital são facilmente observados quando consideramos a afirmação de Silveira (2001, p. 17) de que: "Em um país com quase um terço da sociedade abaixo da linha da pobreza, gastar algo em torno de 40 reais por mês pelo uso mínimo de conexão e conta telefônica é impossível para a maioria da população".

Considerando que os equipamentos e os custos de acesso à Internet ainda não são compatíveis com a renda da maioria da população brasileira, Sorj e Guedes (2005) afirmam que:

\footnotetext{
Os ricos são os primeiros a usufruir as vantagens de uso e/ou domínio dos novos produtos no mercado de trabalho, enquanto a falta destes aumenta as desvantagens dos grupos excluídos. Em ambos os casos, os novos produtos TICs aumentam, em princípio, a pobreza e a exclusão digital. (SORJ; GUEDES, 2005, p. 01).
}

Autores como Macadar e Reinhard (2002, p. 01) reforçam essa posição, afirmando que não somente a pobreza leva à exclusão digital, como também a exclusão digital amplia a condição de exclusão social "Não há dúvida que a exclusão digital aprofunda a exclusão sócio-econômica".

Apesar de a maioria dos discursos sobre a exclusão digital se pautarem inicialmente na questão econômica e de poder aquisitivo da população, considerando as afirmações de autores como Marcuse, é necessário apontar como fator decisivo para o distanciamento entre as classes sociais a veiculação e o domínio da informação. Isso porque, como já afirmava o autor em 1964, "a tecnologia serve para instituir formas novas, mais eficazes e mais agradáveis de controle social" (MARCUSE, 1964, p.18). Quem detém a informação, se apropria dos veículos de difusão e faz uso do que sabe, detém o controle daqueles que não possuem o mesmo conhecimento.

Estar fora do fluxo de informação é estar alienado do mundo e, mais do que isso, é estar 
cada vez mais longe de uma possibilidade de ascensão social, é amargar a condição de oprimido, pois como afirma Silveira (2001, p. 18). “a exclusão digital impede que se reduza a exclusão social (...) Estar fora da rede é ficar fora dos fluxos de informação. Desconhecer seus procedimentos básicos é amargar a nova ignorância."

A apropriação da tecnologia é fundamental para que as pessoas se configurem como cidadãos na Sociedade Informacional.

\begin{abstract}
o mundo da tecnologia também se configura como uma forma de inclusão social. A aprendizagem da informática e o acesso às novas linguagens de comunicação e informação não só possibilitam oportunidades econômicas, de geração de renda, como também representa um capital social. (BAGGIO, 2000, p. 02)
\end{abstract}

A pobreza não se reduzirá com programas assistenciais de alimentos ou saneamento básico somente, mas com o compartilhamento de conhecimentos, com a utilização de ferramentas tecnológicas e com a melhoraria das condições de vida das pessoas. Essa parece ser a questão central da exclusão social na atualidade.

O ranking da International Telecommunication Union - ITU/ONU (União Internacional de Telecomunicações), órgão da ONU (Organização das Nações Unidas), que mede o acesso dos cidadãos de 180 nações à Sociedade da Informação, pelo chamado Índice de Oportunidade Digital (IOD), mostra que as condições de acesso às tecnologias são bem distintas nas diversas partes do mundo (Ilustração 1). 


\section{Digital Opportunity, Top 25 economies, 2007}

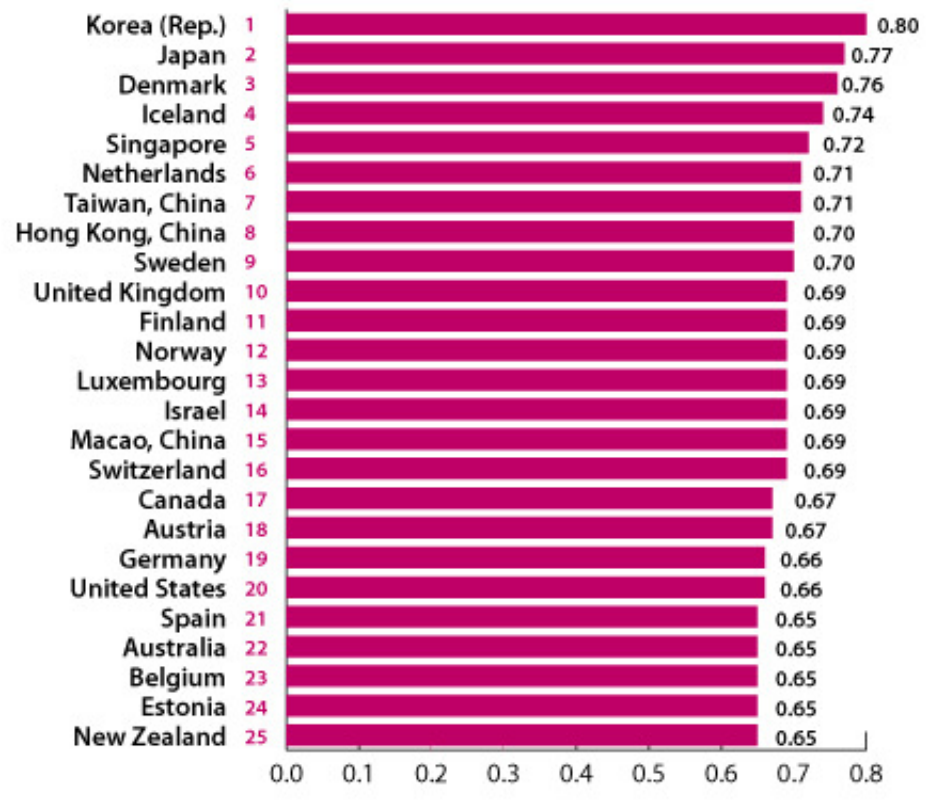

Ilustraç̃o 1: Digital Opportunity, Top 25 econoies, $2007 .^{15}$

O IOD varia de 0.0 a 1.0. e leva em consideração três variáveis principais: oportunidades (cobertura e preços da telefonia móvel e preços de acesso à internet); infra-estrutura (mede as redes fixas, móveis e de acesso à internet e o número de residências com computadores e celulares); e utilização (número de assinantes de internet e banda larga). Ele mostra que os países considerados desenvolvidos e com grande potencial econômico estão à frente do ranking. $\mathrm{O}$ Brasil aparece na $65^{\mathrm{a}}$ posição, com IOD de 0.48, mesma marca de países como Bósnia e Uruguai.

De certa forma, o IOD confirma o fato de que a condição econômica interfere nas condições de acesso às tecnologias, pois são as principais potenciais econômicas do mundo que aparecem nas primeiras posições do ranking (como mostra a ilustração 1). Entretanto, se pensarmos no acesso e uso das tecnologias como fonte de informação e dominação, podemos levantar outros questionamentos como: quem investe na infra-estrutura para acesso da população às TICs? A que parcela da população é dado o acesso? Com quais interesses?

$\mathrm{Na}$ tentativa de refletir sobre essas questões, é interessante observar um pouco melhor a realidade brasileira a partir dos dados apresentados pelo Comitê Gestor da Internet no Brasil

15 FONTE: World Information Society 2007 Report . Disponível em < http://www.itu.int/osg/spu/publications/worldinformationsociety/2007/report.html> Acesso em 03/09/2008 16:00. 
(BALBON, 2008) por meio da Pesquisa sobre o uso das Tecnologias da Informação e da Comunicação no Brasil: TIC Domicílios e TIC Empresas 2007, que aponta que 58\% dos entrevistados não possuem Internet em casa pelo custo elevado, o que reforça a relação entre a condição econômica e a exclusão digital, porém, 16\% declaram não ter Internet em seu domicílio por falta de necessidade ou interesse, o que pode expressar um reforço da afirmação de Lévy (1999, p. 237) de que cada sistema produz seus próprios excluídos e, para aquela parcela na qual as tecnologias (neste caso específico, a Internet) não fazem parte do contexto das pessoas, elas se tornam desnecessárias. A esses números se somam $4 \%$ da população entrevistada que declara não ter Internet em casa por não existir o serviço na localidade, o que possibilita a reflexão de que existem interesses políticos e comerciais na disponibilização deste serviço, já que a rede mundial pode ser acessada por meios diversos. Não disponibilizar o acesso à Internet em algumas regiões pode representar a falta de interesses comerciais e de desenvolvimento nessa área.

As análises acima apresentadas são apenas hipóteses que pretendem ampliar a discussão sobre a exclusão digital no Brasil e no mundo. É essencial que, ao fazer uso dos índices apresentados pelos institutos e pesquisadores, façamos uma leitura crítica. Assim, longe de aceitar a exclusão como algo natural e imutável, é preciso analisar os dados sociais e os índices de acesso da população às tecnologias digitais como ponto de partida para o planejamento de políticas de inclusão nesta área.

Em 2003, a Fundação Getúlio Vargas (FGV) realizou um estudo sobre a exclusão digital no Brasil, criando índices específicos para mensurar essa exclusão nas cidades brasileiras. O estudo resultou em um documento intitulado Mapa da Exclusão Digital ${ }^{16}$ (NÉRI, 2003) que teve como principal fonte de dados as pesquisas do IBGE (Instituto Brasileiro de Geografia e Estatística) e considerou indicadores sociais diversos tais como condições domiciliares, escolaridade da população, renda familiar entre outros.

Segundo o mapa, a cidade com maior índice de inclusão digital no Brasil é São Caetano do Sul - SP, com 41,14\% da população de incluídos digitais ao passo que o menor índice apontado é da cidade de América Dourada - BA, com apenas 0,02\% de incluídos digitais.

Esses números mostram que existe uma grande parte da população excluída dos meios digitais nos municípios brasileiros e que este índice varia muito de um município para outro.

16 O Mapa da Exclusão Digital (2003) é um estudo realizado pela Fundação Getúlio Vargas (FGV), com indicadores sociais das cidades brasileiras. Mais adiante no texto, tratarei do Mapa da Inclusão Digital, do Instituto Brasileiro de Informação e Tecnologia (Ibict) que é de um sistema de monitoramento e cadastro dos pontos de inclusão digital existentes no país. Tratam-se de duas fontes distintas, portanto é preciso observar com atenção as referências às fontes dos dados apresentados. 
Entretanto, é difícil encontrar referências que permitam análise comparada desses dados com outras cidades do mundo, uma vez que os estudos desta natureza não utilizam as mesmas variáveis para a criação de seus índices, nem mesmo fazem uso de uma unidade de medida padrão.

A dispersão dos incluídos digitais no mapa do Brasil é definida de acordo com os índices sociais e econômicos do país, a ilustração abaixo indica as 20 cidades brasileiras com melhor índice de inclusão digital.

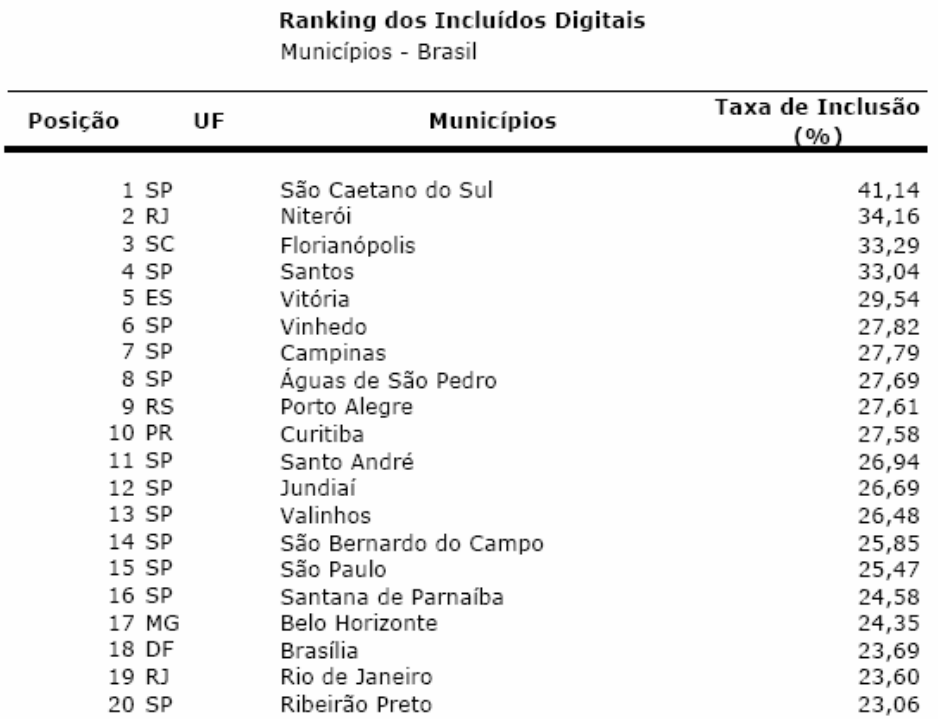

Ilustração 2: Ranking dos Incluídos Digitais - Municípios brasileiros (20 primeiros). ${ }^{17}$.

A análise dos dados das ilustrações 2 e 3 permite observar que os municípios brasileiros com melhores índices estão localizados nas regiões Sul e Sudeste, onde a concentração de renda é maior do que no restante do país. Por outro lado, os municípios com menor taxa de inclusão digital se encontram na região Nordeste, região menos privilegiada em todos os aspectos sociais.

17 FONTE: Mapa da Exclusão Digital (NERI, 2003). Disponível em <http://www2.fgv.br/ibre/cps/mapa_exclusao/apresentacao/MID_RankingGeral.pdf> (Acesso em 07jan2008). 
Ranking dos Incluídos Digitais

Municípios - Brasil

\begin{tabular}{|c|c|c|}
\hline Posição & Municípios & $\begin{array}{c}\text { Taxa de Inclusão } \\
(\%)\end{array}$ \\
\hline $5075 \mathrm{BA}$ & Maetinga & 0,06 \\
\hline $5076 \mathrm{MA}$ & Buritirana & 0,06 \\
\hline $5077 \mathrm{MA}$ & Gonçalves Dias & 0,06 \\
\hline $5078 \mathrm{PA}$ & Curralinho & 0,06 \\
\hline $5079 \mathrm{PE}$ & Manari & 0,06 \\
\hline $5080 \mathrm{PI}$ & Caldeirão Grande do Piauí & 0,06 \\
\hline $5081 \mathrm{AL}$ & Ibateguara & 0,05 \\
\hline $5082 \mathrm{BA}$ & Cairu & 0,05 \\
\hline $5083 \mathrm{MA}$ & Mirinzal & 0,04 \\
\hline $5084 \mathrm{BA}$ & América Dourada & 0,02 \\
\hline
\end{tabular}

Ilustração 3: Ranking dos Incluídos Digitais - Municípios brasileiros (10 últimos) ${ }^{18}$.

Considerando que a taxa de inclusão digital é dada por indicadores sociais, é possível verificar neste ranking que quanto maior a exclusão social, maior o índice de exclusão digital.

Entretanto, voltando às reflexões do sobre a exclusão digital pontuadas no início deste item, podemos entender que estar fora dos fluxos de informação é fator determinante para a condição de exclusão na sociedade da informação e a negação da possibilidade de ascensão social, o que inverte a relação de causa-efeito: quanto maior a exclusão digital, maior a exclusão social.

Seja qual for a perspectiva pela qual olhamos o problema, o fato é que as diferenças sociais e econômicas estão bastante relacionadas quando consideramos a sociedade da informação e suas constantes transformações. O que não significa que a redução da desigualdade digital necessariamente irá reduzir a desigualdade social, pois o tema é bem complexo para ser tratado de forma tão categórica, levando-se em conta que estamos tratando de relações humanas de direito, acesso, cidadania, participação e ao mesmo tempo de poder, dominação e negação de direitos.

Em artigo intitulado As definições da exclusão digital diante das exigências de uma cibercidadania, Sérgio Amadeu da Silveira (2008), refletindo sobre as colocações de Lévy (1999) declara que este autor "não deixa claro que existem variados graus de exclusão, ou ainda, não se preocupou em demonstrar que existem vários tipos qualitativamente distintos de exclusão". Para Silveira, alguns tipos de exclusão "não são superáveis sem a reorganização das práticas sociais", o que deixa claro que incluir digitalmente as pessoas pode ter diferentes significados, dependendo da forma com que entendemos a exclusão e seus diferentes níveis.

18 FONTE: Mapa da Exclusão Digital (NERI, 2003). Disponível em <http://www2.fgv.br/ibre/cps/mapa_exclusao/apresentacao/MID_RankingGeral.pdf> (Acesso em 07jan2008). 


\section{Programas de Inclusão Digital}

O problema da exclusão digital não é somente um problema econômico para garantir o acesso aos equipamentos e infra-estrutura necessários para que todos tenham acesso às TICs, mas essencialmente uma questão de formação e apropriação das tecnologias.

todas as camadas da sociedade precisam se qualificar para acompanhar o desenvolvimento das tecnologias intelectuais, pois é disso que tratamos quando falamos em inclusão na sociedade da informação. A pobreza não será reduzida com cestas básicas, mas com a construção de coletivos inteligentes, capazes de qualificar as pessoas para a nova economia e para as novas formas de sociabilidade (...). (SILVEIRA, 2001, p. 21)

... mas o problema do acesso para todos não pode ser reduzido às dimensões tecnológicas e financeiras geralmente apresentadas. Não basta estar na frente de uma tela, munido de todas as interfaces amigáveis que se possa pensar, para superar uma situação de inferioridade. É preciso, antes de mais nada, estar em condições de participar ativamente dos processos de inteligência coletiva que representam o principal interesse do ciberespaço. (LÉVY, 1999, p.238, grifo do autor).

Tanto Silveira como Lévy afirmam a importância dos processos de participação e do desenvolvimento de inteligências coletivas como fator decisivo para a inclusão digital, porém, nem todos os programas e projetos de inclusão trabalham nessa perspectiva, uma vez que, segundo Castells (1999a), eles estão relacionados a interesses políticos.

O que deve ser guardado para o entendimento da relação entre tecnologia e a sociedade é que o papel do Estado, seja interrompendo, seja promovendo, seja liderando a inovação tecnológica, é um fator decisivo no processo geral, à medida que expressa e organiza as forças sociais dominantes em um espaço e uma época determinados. Em parte, a tecnologia expressa a habilidade de uma sociedade para impulsionar seu domínio tecnológico por intermédio das instituições sociais, inclusive o Estado. (CASTELLS, 1999a, p.50)

Considerando a complexidade do tema da exclusão digital e, reconhecendo que não só os “sistemas de comunicação fabricam seus excluídos" (LÉVY, 1999, p. 237), mas também os governos e sociedades em que estão inseridos têm forte participação nesta realidade, é importante traçar um panorama dos Programas de Inclusão Digital como iniciativas dos governos e sociedade para minimizar o impacto da revolução tecnológica informacional no distanciamento das classes sociais. 
Programas de inclusão estão sendo desenvolvidos em todo o mundo, na tentativa de minimizar o distanciamento das pessoas menos privilegiadas à tecnologia.

No Brasil, já existem algumas iniciativas governamentais, de organizações sociais e da iniciativa privada. O Instituto Brasileiro de Informação em Ciência e Tecnologia (Ibict) realiza um constante trabalho de monitoramento e cadastro dos Pontos de Inclusão Digital ${ }^{19}$ (PID) em funcionamento no país. Este trabalho chama-se Mapa da Inclusão Digital ${ }^{20}$. Segundo este levantamento, existem no Brasil 17.870 PIDs, distribuídos em 149 programas governamentais e iniciativas do terceiro setor.

A análise de cada uma dessas iniciativas deve passar por uma reflexão sobre os objetivos de sua implantação e seus reais serviços prestados uma vez que muitos dos pontos cadastrados nesta base de dados não representam necessariamente um local de acesso à população nem instrumentalizam os usuários para a participação e formação de coletivos inteligentes, capazes de atuar na sua realidade, criar novas tecnologias e transformar seu entorno.

Algumas iniciativas representam apenas um computador com acesso à rede e se quer permitem acesso da população local. Assim, o gráfico abaixo, apesar de servir como um panorama nacional de iniciativas de inclusão digital deve ser observado com cautela e reflexão, pois este tipo de levantamento também reflete interesses políticos.

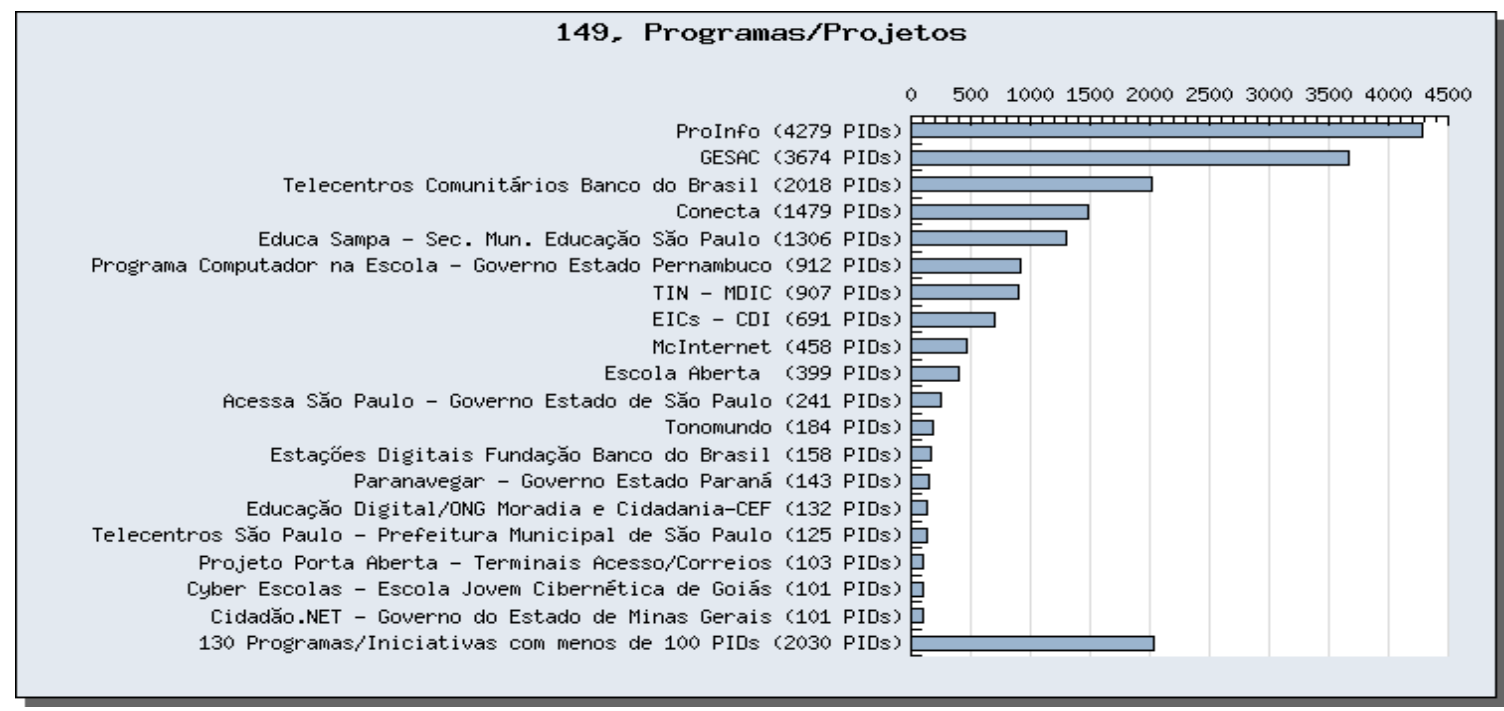

Ilustração 4: Total de PIDs apoiados pelos Programas/Projetos. ${ }^{21}$

19 Pontos de Inclusão Digital (PID) são pontos da acesso às tecnologias digitais, tais como: telecentros, infocentros, salas de informática, centros de inclusão digital, lan house, cyber café, etc. Os PIDs são cadastrados pelas próprias instituições no Portal da Inclusão Digital e são eles que compõem os dados do Mapa da Inclusão Digital.

20 O Mapa da Inclusão Digital (Ibict) pode ser consultado no Portal da Inclusão Digital, no endereço eletrônico do Ministério da Ciência e Tecnologia (MCT) (http://www.mct.gov.br/). Os dados apresentados se referem ao acesso feito em novembro de 2008.

21 FONTE: Mapa da Inclusão Digital. Disponível em: <http://www.mct.gov.br>. Acesso em nov. 2008. 
Os números não são o único parâmetro para avaliar as políticas públicas para a inclusão digital. É preciso ir mais a fundo e verificar quais os objetivos do projeto, que recursos são disponibilizados à população, saber qual população é atendida por este programa, de que forma é feito este atendimento etc. Só assim será possível verificar se de fato os programas incluem digitalmente os cidadãos ou se utilizam desse discurso para reforçar o distanciamento entre incluídos e excluídos digitais.

A distribuição territorial dos programas também precisa ser analisada. Nesta mesma base de dados, é possível verificar a quantidade de PIDs existentes em cada estado brasileiro. São Paulo é o estado com maior número de pontos cadastrados. São 4.084 PIDs, distribuídos em 58 programas diferentes. O segundo estado com o maior número de PIDs é Minas Gerais, com 2.066 pontos, como mostra a ilustração 5 .

Ao observar estes números, é possível verificar que aparentemente não existe uma regra para que um estado tenha mais PIDs do que outro, afinal, essa distribuição não segue o critério de dimensão do território (quanto maior, possui mais PIDs), nem o critério populacional (quanto maior o número de habitantes, mais PIDs) nem o critério sócio-econômico (quanto mais pobre, mais PIDs). Essa análise reforça a questão dos interesses políticos, mercadológicos e de mobilização da população.

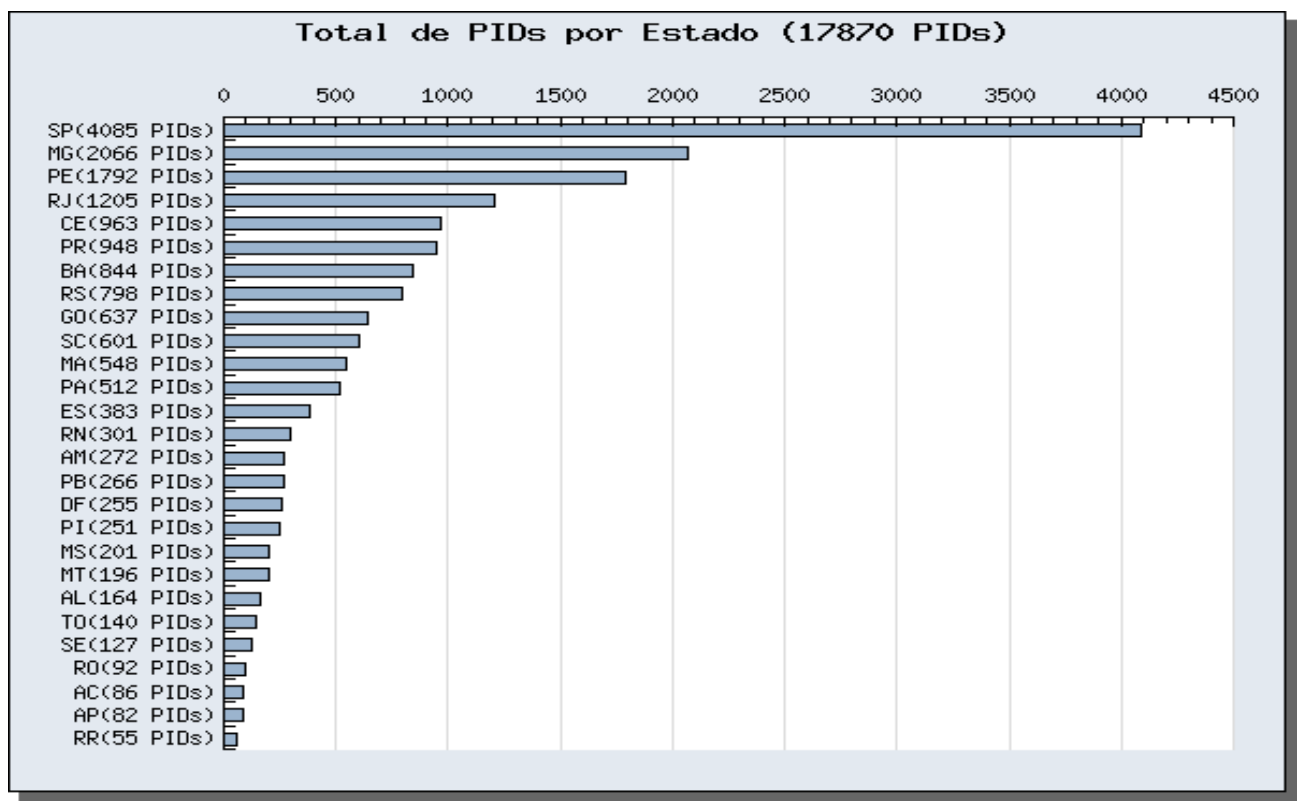

Ilustração 5: Total de PIDs por Estado ${ }^{22}$.

22 FONTE: Mapa da Inclusão Digital. Disponível em: <http://www.mct.gov.br>. Acesso em nov. 2008. 
Alguns pontos de inclusão digital são implantados com apoio de empresas que visualizam, em determinada região, uma população potencialmente consumidora para seus produtos. Em outras iniciativas, busca-se a implantação de tecnologias em comunidades realmente isoladas, com intuito de torná-las cidadãs e incluídas. Em outros lugares ainda, os programas começaram a existir porque um grupo de pessoas julgou importante trazer as tecnologias para os moradores da comunidade.

Não é objetivo deste estudo, porém, descrever cada ação de inclusão digital existente no país, por isso, neste capítulo, irei descrever apenas algumas iniciativas, com intuito de apresentar exemplos de programas de abrangência nacional, estadual, municipal e local.

\subsection{Programas de inclusão digital de iniciativa do governo federal}

As duas iniciativas com maior número de PIDs cadastrados no Mapa da Inclusão Digital são iniciativas do governo federal e estão espalhadas por todo o território nacional, mas têm características e formas de gestão bastante distintas.

O Programa Nacional de Informática na Educação (ProInfo) foi criado em 1997 pelo Ministério da Educação e tem como objetivo promover o uso das tecnologias como ferramenta de enriquecimento pedagógico no ensino público fundamental e médio. $\mathrm{O}$ funcionamento do programa se dá de forma descentralizada, administrado por pólos regionais, um em cada estado do país.

O programa tem como principal público-alvo os professores da rede pública de ensino e foi instituído principalmente para sanar as necessidades de formação permanente deles, além de possibilitar o contato dos educadores com os recursos tecnológicos. Busca-se, com isso, uma inclusão digital por meio da formação dos professores que podem atuar como multiplicadores nas escolas.

Cada coordenação estadual do programa tem o papel de introduzir as Tecnologias de Informação e Comunicação (TICs) nas escolas públicas, além de articular os esforços e as ações desenvolvidas no setor, em especial as ações dos Núcleos de Tecnologia Educacional (NTE). Os NTEs são locais dotados de infra-estrutura de informática e comunicação que reúnem educadores e especialistas em tecnologia que atuam como formadores de outros educadores.

O ProInfo é desenvolvido pela Secretaria de Educação à Distância - SEED, por meio do Departamento de Infra-Estrutura Tecnológica - DITEC, em parceria com as Secretarias Estaduais e 
algumas Municipais de Educação. ${ }^{23}$

É importante pontuar que o programa, apesar de ter uma abrangência nacional, é bastante pontual, pois atinge apenas uma parcela da população - professores da rede pública de ensino, o que não dá conta da diminuição da desigualdade digital do país. Por outro lado, acredito que a atuação dos educadores como mediadores dos alunos e as tecnologias é um ponto bem interessante para a inclusão digital de uma parcela considerável dos excluídos. É preciso, contudo, pontuar a necessidade de equipamentos adequados nas escolas e formação de qualidade para os professores.

O segundo programa com maior número de PIDs cadastrados - o Governo Eletrônico Serviço de Atendimento ao Cidadão (Gesac) - é parte das iniciativas do Governo eletrônico e também se constitui em uma ação do governo federal que criou o Programa Brasileiro de Inclusão Digital (PBID). Segundo Trevisan (2005, p. 55), este programa possui, além do Gesac, outros dois projetos: o PC conectado e Casa Brasil ${ }^{24}$.

O Gesac foi criado em 2003 e tem como meta "disponibilizar acesso à Internet e mais um conjunto de outros serviços de inclusão digital a comunidades excluídas do acesso e dos serviços vinculados à rede mundial de computadores. ${ }^{25}$ " No programa, são priorizadas as regiões com baixo IDH e onde as redes de telecomunicações tradicionais não oferecem acesso local à Internet em banda larga. A conexão via satélite do Gesac permite que mais de 25.000 terminais estejam conectados à rede.

$\mathrm{Na}$ ilustração 4, é apontada a existência de 3.674 pontos de presença do Gesac. Neste número são contabilizados os centros de gerência de onde se faz o monitoramento de toda a estrutura do Gesac e os pontos de presença, que são escolas, prédios públicos, telecentros e, muitas vezes, correspondem aos demais programas citados no gráfico como o Programa Casa Brasil. Portanto, a leitura do Mapa da Inclusão Digital deve estar atenta ao fato de que o número absoluto de iniciativas cadastradas não corresponde ao número total de equipamentos de acesso às tecnologias no país, pois existe sobreposição de alguns programas.

\subsection{Programas de inclusão digital de iniciativa do governo estadual}

Como iniciativa estadual, já fazendo um recorte geográfico para esta pesquisa, apresento o

23 http://www.proinfo.mec.gov.br

24 Tratarei do Programa Casa Brasil mais adiante, neste capítulo, quando for explicitar as iniciativas de inclusão digital existentes na cidade de São Paulo.

25 http://www.inclusao.ibict.br 
principal programa de inclusão digital do governo do Estado de São Paulo: o programa Acessa São Paulo.

O programa está em funcionamento dede novembro de 2005 e tem por base a instalação de infocentros, em todo o território do Estado de São Paulo, para acesso gratuito da população em geral.

Segundo Trevisan (2005, p. 53), o programa tem três tipos de infocentro. Na capital, funcionam em parceria com iniciativas da sociedade como associação de moradores e ONGs (Organizações Não-governamentais). No interior, atuam em parceria com as prefeituras, dividindo com elas a responsabilidade pela manutenção do espaço. $\mathrm{O}$ terceiro modelo corresponde aos postos públicos como estações de metrô, unidades do Programa Poupatempo entre outros.

Segundo o endereço eletrônico do programa ${ }^{26}$, foram instalados, até novembro de 2008, 505 unidades de infocentros espalhadas pelo estado (capital e interior). Desse total, 85 se encontram na capital, sendo que 34 unidades de atendimento estão em funcionamento nos postos públicos estaduais da cidade e as demais 51 unidades funcionam em parceria com o terceiro setor. ${ }^{27}$

\begin{tabular}{|c|c|}
\hline \multicolumn{2}{|c|}{ Unidades da Capital - Programa Acessa São Paulo (nov/2008) } \\
\hline $\begin{array}{l}\text { Centro (7 unidades) } \\
\text { CPTM Brás } \\
\text { Metrô São Bento } \\
\text { Metrô Sé } \\
\text { Poupatempo Sé } \\
\text { Poupatempo Sé II - Secretaria da Fazenda } \\
\text { SEADE } \\
\text { SEADS }\end{array}$ & $\begin{array}{l}\text { Leste (7 unidades) } \\
\text { CPTM Dom Bosco } \\
\text { CPTM Itaim Paulista } \\
\text { CPTM José Bonifácio } \\
\text { CPTM São Miguel Paulista } \\
\text { CPTM Tatuapé } \\
\text { EMTU São Mateus } \\
\text { Poupatempo Itaquera }\end{array}$ \\
\hline $\begin{array}{l}\text { Sul (11 unidades) } \\
\text { ADEVA } \\
\text { Biblioteca do Palácio } \\
\text { Bom Prato Santo Amaro } \\
\text { CIC Feitiço da Vila (desativado temporariamente) } \\
\text { CPTM Granja Julieta } \\
\text { CPTM Socorro } \\
\text { Hospital do Servidor Público } \\
\text { Metrô Campo Limpo } \\
\text { Parque Fontes do Ipiranga } \\
\text { Poupatempo Santo Amaro } \\
\text { Secretaria do Planejamento }\end{array}$ & $\begin{array}{l}\text { Oeste (6 unidades) } \\
\text { CIC Oeste - Jaraguá (desativado temporariamente) } \\
\text { CPTM Barra Funda } \\
\text { CPTM Pinheiros } \\
\text { Estação Especial da Lapa } \\
\text { Memorial da América Latina } \\
\text { Parque Baby Barioni }\end{array}$ \\
\hline
\end{tabular}

26 Dados atualizados do Programa Acessa São Paulo podem ser encontrados em $<$ http://www.acessasp.sp.gov.br/html/modules/mxdirectory/viewcat.php?cid=4>

27 Podem ser consultadas no Mapa da Inclusão Digital (Portal da Inclusão Digital - Ministério da Ciência e Tecnologia).

28 FONTE: Programa Acessa São Paulo. Disponível em <http:// www.acessasaopaulo.sp.gov.br> Acesso em jan/2008. 
A procura pelos infocentros é grande, uma vez que foram instalados em lugares estratégicos de grande circulação de pessoas (poupatempos, estações de trens e metrô etc), mas o tempo de acesso nem sempre favorece um real aproveitamento dos recursos disponibilizados pelo programa.

\footnotetext{
A duração de acesso é quase sempre limitada a trinta minutos, ou vinte nos postos públicos, limitando-se, assim, o uso mais aprofundado desses equipamentos. Também impedem o uso a crianças menores de 11 anos, e o acesso a sites de jogos, ou com conteúdo pornográficos, ou que pregam o preconceito a determinados segmentos sociais. (TREVISAN, 2005, p. 56)
}

Algumas unidades oferecem cursos de informática aplicada como elaboração de currículos, porém existe fila de espera para efetuar a matrícula em muitos lugares (idem).

Um recente projeto lançado pela Secretaria da Educação do Estado de São Paulo pode ser entendido como um desdobramento do Programa Acessa São Paulo. Esta iniciativa recebeu o nome de Acessa Escola e tem por objetivos a otimização dos recursos de informática existentes na escola por meio do acesso livre da sala de informática.

O Acessa Escola ${ }^{29}$ foi instituído pela Resolução da SE-37, de 25 de abril de 2008, sendo implantado na Rede Estadual de Ensino neste mesmo período. O programa, além de visar o acesso de toda comunidade escolar aos recursos tecnológicos, buscando o enriquecimento cultural e educativo, pretende capacitar jovens alunos das escolas como monitores das salas de informática. A Fundação do Desenvolvimento Administrativo (Fundap) é a instituição responsável pela contratação e capacitação desses alunos que recebem uma ajuda de custo mensal para dedicar quatro horas de trabalho na sala de informática da escola.

O programa ainda está em fase de implantação e estruturação de sua gestão, porém já pode ser visto como um salto importante para o trabalho de inclusão digital nas escolas uma vez que a maioria delas não possuía uma pessoa para cuidar dos equipamentos da sala de informática e por isso, raramente os materiais disponíveis eram utilizados.

\subsection{Programas de inclusão digital de iniciativa do governo municipal}

Também obedecendo ao recorte desta pesquisa, é importante destacar a principal iniciativa do

\footnotetext{
29 http://www.acessaescola.sp.gov.br
} 
governo municipal da cidade de São Paulo, o Programa Telecentro.

Até o ano de 2001, segundo o Plano de Inclusão Digital e Cidadania (SÃO PAULO, 2003), não existia na cidade nenhuma ação de inclusão digital por parte da prefeitura. Naquele ano, foi implantado o Programa Telecentro que já em 2003 contava com 61 unidades e 183 mil usuários cadastrados.

Dentre os objetivos deste programa estão: acesso; diminuição dos índices de exclusão digital e social; capacitação profissional; disseminação do software livre; participação popular através dos conselhos gestores.

Todos os serviços oferecidos pelos telecentros municipais são gratuitos e, além do acesso livre, os usuários podem se cadastrar para os cursos oferecidos nestes espaços.

Cada telecentro do programa dispõe de 20 computadores ligados em rede e operando com sistema GNU/Linux. O programa possui três tipos de telecentro (SÃO PAULO, 2003):

- Telecentros operados sob administração direta: são geridos diretamente pela Prefeitura de São Paulo.

- Telecentros conveniados com entidades da sociedade: Instalações em parceria com ONGs.

- Telecentros instalados em Centros Educacionais Unificados (CEUs): são equipamentos instalados em unidades educacionais de grande porte, com objetivo de oferecer serviços complementares às escolas.

Segundo o Plano (SÃO PAULO, 2003), “a priorização do público-alvo se dá por critérios territoriais, privilegiando-se as regiões da cidade com Índices de Desenvolvimento Humano mais baixos". O perfil dos usuários, segundo este mesmo documento, prova que a exclusão digital na cidade faz parte da exclusão social mais ampla: 9\% dos usuários não possuem renda familiar e 34\% estão na faixa de um a dois salários mínimos. Quanto à escolaridade, $47 \%$ não possuem o Ensino Fundamental completo.

Em novembro de 2008, existia na cidade 299 telecentros da prefeitura, de acordo com os dados disponíveis no endereço eletrônico da Coordenadoria de Inclusão Digital (2008) ${ }^{30}$. Além das características dos usuários do programa, também podemos observar que o mapa da distribuição dos telecentros pela cidade se mostra semelhante ao Mapa da Exclusão Social (Ilustração 8), o que revela a tentativa de minimizar os impactos causados pela ausência deste tipo de serviço nos

30 Coordenadoria de Inclusão Digital - Secretaria para Participação e Parceria. Prefeitura do Município de São Paulo, $<$ http://portal.prefeitura.sp.gov.br/secretarias/participacao_parceria/coordenadorias/inclusao_digital.> 
bolsões de exclusão do município.

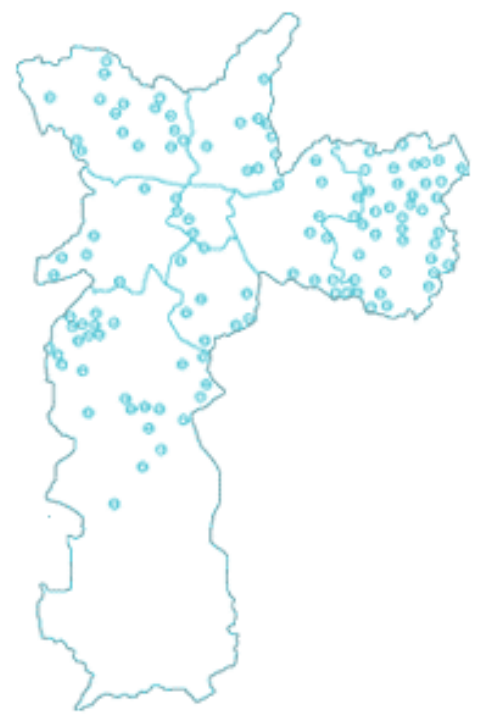

Zona Leste

616.418 usuários cadastrados

113 telecentros ativos

Zona Norte

237.597 usuários cadastrados

50 telecentros ativos

Centro

94.457 usuários cadastrados

22 telecentros ativos

Zona Oeste

92.895 usuários cadastrados

$\mathbf{1 6}$ telecentros ativos

Zona Sul

383.500 usuários cadastrados

$\mathbf{9 8}$ telecentros ativos

Ilustração 7: Distribuição dos telecentros na cidade de São Paulo ${ }^{31}$.

O programa apontava a existência de 1.424.867 usuários cadastrados até novembro de 2008, o que demonstra sua importância para a população da cidade de São Paulo.

\subsection{Programas de inclusão digital de iniciativa da rede privada e do Terceiro Setor}

O conceito de Responsabilidade social atrelado às vantagens fiscais como abatimento em impostos têm incentivado empresas de todos os setores a desenvolver seus programas de incentivo a projetos sociais diversos e, algumas empresas como o Banco do Brasil, também têm investido no setor da inclusão digital.

A iniciativa do Banco do Brasil é a terceira com maior número de PIDs cadastrados no Mapa da Inclusão Digital. O programa recebe o nome da própria empresa (Programa de Inclusão Digital do Banco do Brasil) e tem abrangência nacional, estando implantado em quase todos os estados brasileiros.

O Programa de Inclusão Digital do Banco do Brasil é uma ação da política de responsabilidade socioambiental da empresa, que ao modernizar seus equipamentos tecnológicos,

\footnotetext{
${ }^{31}$ FONTE: Coordenadoria da Inclusão Digital - Secretaria para Participação e Parceria (Outubro/2008).
} 
começou a fazer doações dos equipamentos substituídos para comunidades carentes, visando a implantação de Telecentros Comunitários. Além da doação dos computadores, o Banco do Brasil se responsabiliza pelo treinamento dos monitores e pela articulação de parceiras, fomentando o desenvolvimento local.

A estrutura do programa é montada em parceria com outras organizações (sociais, estatais ou privadas) e, segundo dados da Ilustração 4, o projeto possui atualmente 2.018 telecentros comunitários em todo o país que beneficiam mais de 4 milhões de usuários por ano.

De acordo com as premissas deste programa, ele pode servir a vários propósitos como:

\begin{abstract}
acesso à Internet; treinamento no uso básico de um computador; treinamento à distância; prestação de pequenos serviços como edição, digitalização e impressão de documentos; geração de trabalho e renda, verificação de cotação de preços; preenchimento de propostas de microcrédito e abertura de contas; acesso aos chats de discussões temáticas; formação de redes de interesse comercial para trocas, vendas e compras de produtos; elaboração de reforço escolar para crianças; produção cultural de rádios e vídeos; telesaúde e tele-cidadania para regiões distantes dos grandes centros; popularização de e-mails; e centenas de atividades que a própria comunidade inventa e reinventa através do uso e apropriação do novo instrumento tecnológico, com qual supera suas dificuldades locais e transforma sua realidade. ${ }^{32}$
\end{abstract}

Outras instituições que têm desenvolvido programas de inclusão digital, na tentativa de diminuir as barreiras sociais e tecnológicas, são as instituições do terceiro setor. Muitas delas atuam em parceria com programas governamentais dos quais tratei um pouco nos itens anteriores, mas algumas têm projeto próprio, desenvolvidos em parceria com empresas e outros setores da sociedade.

O Comitê para Democratização da Informática (CDI) é uma organização nãogovernamental que desenvolve programas dessa natureza por meio de suas Escolas de Informática e Cidadania (EICs). As EICs, criadas em 1995, são compreendidas como

como espaços informais de ensino, que promovem não só a capacitação técnica em Informática, mas a abertura de novos horizontes para milhares de jovens através da reflexão e do debate de temas relacionados a sua realidade social. ${ }^{33}$

As EICs são estruturadas pelo CDI em pareceria com associações comunitárias, empresas, ONGs, órgãos governamentais e instituições que atendam públicos com necessidades especiais.

32 Dados disponíveis em <http://www44.bb.com.br/appbb/portal/bb/id/Parcerias.jsp> Acesso em out 2008.

33 Comitê para Democratização da Informática <http://www.cdi.org.br> 
Estão espalhadas em países como Chile, México e Argentina.

A primeira EIC brasileira foi estruturada a partir da parceria entre o CDI e a Philips, empresa ligada ao setor de tecnologia em 2002 e hoje, segundo os dados do próprio CDI, existem 891 EICs distribuídas em 19 estados brasileiros.

Os educadores das EICs são voluntários da Philips e recebem capacitação do CDI para a implantação dos programas de educação que utilizam da metodologia baseada nos estudos de Paulo Freire.

\begin{abstract}
A metodologia utilizada baseia-se nos ensinamentos do educador Paulo Freire, segundo os quais o aluno deve ser colocado como sujeito atuante na transformação da realidade e no seu aprendizado, com subsídios para que este aluno tenha um livre entendimento sobre o mundo que o cerca. ${ }^{34}$
\end{abstract}

\title{
2.5. Programas de inclusão digital na cidade de São Paulo
}

... uma política de inclusão digital com objetivos ambiciosos passa necessariamente pela implantação de telecentros comunitários. (SÃO PAULO, 2003).

O município de São Paulo é exemplo de como os programas de inclusão digital são necessários até mesmo em grandes centros urbanos. Uma das maiores cidades do país, São Paulo é responsável por $12 \%$ do PIB brasileiro e $36 \%$ de toda a produção de bens e serviços do Estado de São Paulo, segundo dados do IBGE. ${ }^{35}$

A população paulistana possui uma ampla rede de serviços e infra-estrutura. Quase a totalidade da população $(98,6 \%)$ é servida pela rede de abastecimento de água e $87,2 \%$ das residências estão ligadas a rede de esgotos. 99,99\% dos domicílios estão ligados à rede elétrica e $67,2 \%$ possui cobertura de telefonia fixa, porém, a distribuição desses serviços é bastante heterogênea na cidade.

As subprefeituras de Parelheiros e Capela do Socorro, ambas na periferia Sul, apresentam os índices de cobertura de esgoto mais baixos 17,2\% do que o índice do município. Quanto à presença de telefonia fixa nos domicílios, o índice é ainda mais diverso entre as regiões. A baixa taxa de 67,2\% cai para 34,1\% em Parelheiros (Zona Sul), 38,3\% em Perus (Zona Norte) e 40,9\% em São

\footnotetext{
${ }^{34}$ Comitê para Democratização da Informática <http://www.cdi.org.br $>$

35 Os dados da cidade de São Paulo foram retirados do portal da prefeitura, em seção intitulada "Município em Dados", uma extensa compilação de dados do município, que tem como fontes de dados os números de institutos especializados como o IBGE (Instituto Brasileiro de Geografia e Estatística), Ministério do trabalho e Fundação SEADE (Sistema Estadual de Análise de Dados). Disponível em <http://www9.prefeitura.sp.gov.br/sempla/md/index.php?texto=apresentacao> Acesso em: setembro de 2008.
} 
Miguel (Zona Leste).

São Paulo é portanto uma cidade de contrastes e com grande diversidade de índices sociais. Estudo realizado pela prefeitura do município, sob a coordenação de Aldaíza Sposati (2000) e entidades como PUC-SP e Instituto Pólis, revela que existem, na cidade, grandes bolsões de exclusão social.

O Mapa da Exclusão Social do município de São Paulo mostra que há grande concentração de renda, serviços e infra-estrutura nos bairros e distritos do centro da cidade, ao passo que nas periferias de todas as extremidades (Norte, Sul, Leste e Oeste), concentram-se os grandes bolsões de exclusão.

Entre os excluídos e incluídos existem índices de variação como mostra a legenda da ilustração abaixo, que permite observar no mapa que o grau de exclusão aumenta gradativamente à medida em analisamos o centro da cidade e vamos nos aproximando das extremidades sul e leste.

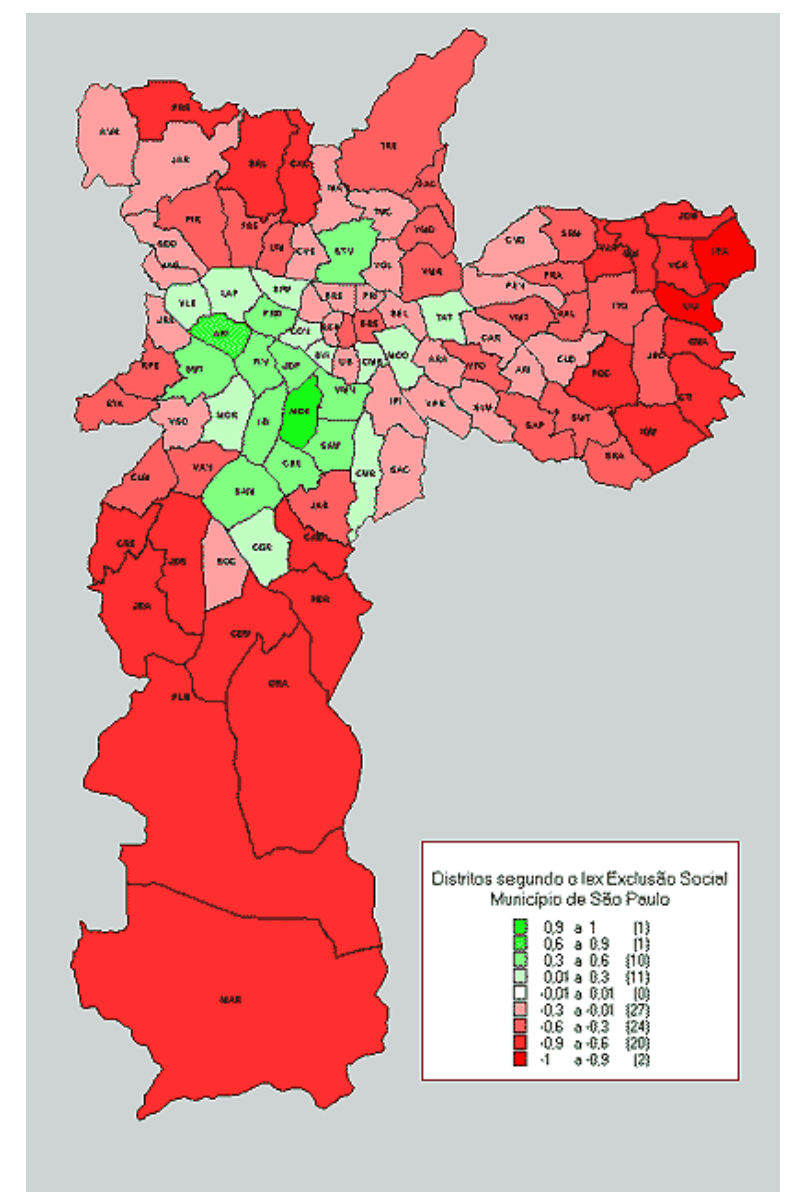

Ilustracão 8: Mapa da Exclusão Social da Cidade de São Paulo ${ }^{36}$.

\footnotetext{
${ }^{36}$ FONTE: SPOSATI, A. (coord.) Mapa da Exclusão Social.
} 
Os bolsões de exclusão e a falta de eqüidade de serviços e condições de vida pelo território paulistano revelam os motivos para a cidade, mesmo sendo uma das maiores cidades brasileiras, estar na $15^{\mathrm{a}}$ posição no Ranking dos Incluídos Digitais do Brasil (NERI, 2003), com apenas 25,47\% de sua população incluída digitalmente.

Como o índice de excluídos digitais é maior do que o de incluídos, programas de inclusão digital se fazem necessários na cidade. Dos 17.613 PIDs cadastrados no país até novembro de 2008, 2.138 PIDs estão em funcionamento na cidade de São Paulo ${ }^{37}$.

As principais iniciativas, já apresentadas nos itens anteriores são: o Programa do governo estadual Acessa São Paulo, com 85 unidades na capital e o programa da prefeitura, com 299 unidades ativas de telecentro.

Além desses programas estadual e municipal, mantidos com ou sem parceria de instituições sociais, existem na cidade, dispersas pelo território, iniciativas particulares de ONGs e movimentos sociais para a inclusão digital como as Escolas de Informática e Cidadania (EICs) do Comitê para a Democratização da Informática (CDI) e programas de inclusão do Governo Federal como o projeto Casa Brasil.

"O Projeto Casa Brasil é uma iniciativa que reúne esforços de diversos ministérios, órgãos públicos, bancos e empresas estatais para levar inclusão digital, cidadania, cultura e lazer às comunidades de baixa renda." ${ }^{38}$ São pontos de acesso às tecnologias de informação e comunicação em comunidades de baixa renda, construídos e administrados em parcerias de organizações do Terceiro Setor. Estão em funcionamento, no território nacional, mais de 40 unidades do Programa Casa Brasil ${ }^{39}$, sendo que, no município de São Paulo, se encontram quatro delas. A ilustração abaixo apresenta essas unidades por meio das organizações parceiras. São duas unidades na Zona Sul, uma na Zona Norte e uma na Zona Leste da cidade.

\begin{tabular}{|c|c|}
\hline $\begin{array}{c}\text { Unidade do Programa Casa Brasil } \\
\text { Organização Parceira }\end{array}$ & Região (bairro / distrito) \\
\hline Instituto Arte e Sustento & Capão Redondo \\
\hline Instituto Pombas Urbanas & Cid. Tiradentes \\
\hline Instituto de Ação Cultural e Ecológica & Pirituba \\
\hline Prefeitura Municipal de São Paulo & Parque Santo Antônio, Distr. M'Boi Mirim \\
\hline
\end{tabular}

Ilustracão 9: Unidades do Programa Casa Brasil na Cidade de São Paulo. ${ }^{40}$

37 Segundo dados do Mapa da Inclusão Digital (Portal da Inclusão Digital - Ministério da Ciência e Tecnologia).

38 Retirado do endereço eletrônico do Programa Casa Brasil disponível em <http://www.casabrasil.gov.br> . Acesso em jan 2008.

39 Dados atualizados podem ser encontrados no endereço eletrônico do Programa Casa Brasil acima citado.

40 FONTE: Programa Casa Brasil. Disponível em <http://www.casabrasil.gov.br> Acesso em jan/2008. 
Os pontos de acesso às Tecnologias de Informação e Comunicação (TICs) em São Paulo têm crescido a cada dia, o que justifica a importância de um estudo sobre este equipamento e o impacto causado na vida de seus usuários. É difícil, contudo, precisar o número de pessoas que utilizam esses programas, porém, pelos dados apresentados pelo programa Telecentro da prefeitura, podemos ter uma idéia deste universo. O programa municipal possui cerca de 1.409 .745 usuários cadastrados nas 299 unidades $^{41}$.

\subsection{Telecentros}

Trevisan (2005), em sua dissertação de mestrado, intitulada Por mares nunca dantes navegados: estudos para a inclusão da população de baixa renda na sociedade da informação, analisa diversos programas de inclusão digital existentes no país e no mundo, descrevendo e qualificando-os. O estudo aborda 14 iniciativas, sendo nove iniciativas nacionais e cinco internacionais. A maioria das experiências apresentadas possui como eixo principal a implantação de telecentros, objeto de estudo também desta pesquisa.

$\mathrm{O}$ autor define telecentros como

um espaço físico, públicos ou não, onde são alocados alguns computadores conectados à internet para uso comunitário. Estes espaços costumam oferecer cursos de informática, e acesso à rede mundial de computadores como suporte para o trabalho, o estudo e o lazer. (TREVISAN, 2005, p. 12).

Ele aponta que existem diferenças significativas entre os vários programas de telecentros, "além de variações nos serviços oferecidos, na infra-estrutura, e na existência ou não de conexões com outros serviços públicos, como as bibliotecas, postos de saúde, etc." (idem). O que mostra a necessidade de se fazer um panorama das categorias e definições de telecentros.

O modelo de telecentro é utilizado principalmente nos países mais pobres, onde os governos possuem menos recursos para investir, pois este formato é mais barato, mas é também incompleto. (TREVISAN, 2005, p. 12).

Segundo Silveira (2001, p.33), essa experiência foi amplamente empregada na Escandinávia e depois se espalhou para vários países do mundo. Takahashi (2000, p. 34) afirma que "o termo telecentro tem sido utilizado genericamente para denominar as instalações que prestam serviços de

\footnotetext{
41 Este número aparece detalhado acima, na ilustração 7.
} 
comunicações eletrônicas para camadas menos favorecidas, especialmente nas periferias dos grandes centros urbanos ou mesmo em áreas mais distantes".

Silveira (2001, p.33) define telecentro como "um espaço físico em que são alocados alguns computadores conectados à Internet para uso comunitário, em geral gratuito".

Darelli (2003) faz uma definição similar "um centro de alta tecnologia que oferece serviços totalmente informatizados à população em geral e ao segmento econômico menos privilegiado, além de ser um grande apoio ao processo educativo local".

O que há de comum nas definições apresentadas é o fato de que o telecentro apresenta-se como um espaço importante na tentativa de minimizar a distância digital da sociedade, permitindo que a parcela menos privilegiada da população entre em contato com as TICs.

Atualmente, segundo Trevisan, existem muitas experiências de telecentros em curso em todas as partes do mundo, tanto nos países ricos como nos menos ricos.

São experiências de várias naturezas, patrocinadas por empresas privadas, fomentadas por ações governamentais de âmbito federal, estadual ou municipal, por ações de organizações nãogovernamentais, instituições de ajuda internacionais, iniciativas do meio acadêmico, entre outras. (TREVISAN, 2005, p. 45)

Os centros de tecnologia chamados telecentros têm diferentes origens e configurações, dependendo dos objetivos de sua criação. Alguns autores fazem a definição e classificação desses equipamentos:

Delgadillo et. al. (2003, p. 8,9) distingue três tipos de experiências relacionadas com o acesso público às tecnologias digitais:

- Telecentros comunitários;

- Cibercafés ou cafés Internet;

- Outras atividades de conectividade.

Telecentros comunitários, objeto desta pesquisa, são definidos pelos autores como "locais de encontros e intercâmbio, espaços de aprendizagem, crescimento pessoal e mobilização para resolver problemas e necessidades da comunicação" (DEGALDILLO et. al. 2003, p. 08). São iniciativas que visam utilizar as tecnologias como instrumento para o desenvolvimento humano de uma determinada comunidade.

Os cibercafés ou café Internet, cada vez mais comuns em grandes cidades, têm por finalidade gerar lucro para os seus proprietários e, segundo esses autores, "o interesse social ou de desenvolvimento não existe - se existir, ocupa um lugar secundário”. (Idem, p. 09)

Como outras atividades de conectividade, os autores apresentam exemplos como redes 
acadêmicas, serviços de informação pública, sistemas de compras etc. Para eles, ainda que esses serviços sejam relevantes para o desenvolvimento humano, não se constituem em telecentros comunitários.

Laipelt et.al. (2003, p. 3-5) disserta sobre outras três categorias, que julga predominantes:

- telecentros comerciais

- telecentros cívicos

- telecentros comunitários

Para as autoras, telecentros comerciais são aqueles "desenvolvidos por empresas privadas e proporcionam acesso público às TICs mediante o pagamento de uma tarifa”. (LAIPELT et.al., 2003, p. 03). Nessa categoria encontram-se os cibercafés, telecentros em cadeias (cabines públicas) e tendas telefônicas (comuns na África Ocidental e na Índia).

Telecentros cívicos "são aqueles que funcionam em instituições como escolas, universidades e bibliotecas públicas e cujo eixo principal de trabalho não é a atividade do telecentro como tal, já que este é oferecido ao público como complemento de seus outros serviços” (Idem, p. 04). Nessa categoria encontram-se os telecentros universitários (salas pró-aluno) e telecentros escolares.

Telecentros comunitários para essas autoras "são iniciativas que disponibilizam acesso às TICs, sobretudo à Internet, garantindo acesso público e universal para captação, geração, prospecção e distribuição do conhecimento, servindo para facilitar e estimular a participação cidadã da comunidade" (Idem, p. 05). Nessa categoria se encontram os telecentros municipais e os telecentros básicos (unidades pequenas, em geral mantida por ONGs).

Gómez et.al. (1999, p. 222) apresenta a classificação dos telecentros em seis tipos:

- Telecentro básico (operações pequenas, em zonas rurais, sem fins lucrativos);

- Telecentros em cadeia (operados independentemente pelos seus proprietários, porém coordenados centralmente);

- Telecentro cívico (aqueles existentes em bibliotecas públicas, escolas, universidades, organizações comunitárias);

- Cibercafés (de caráter comercial);

- Telecentros comunitários multipropósito (oferecem mais do que serviços básicos de conectividade);

- Tendas telefônicas (prestam serviços telefônicos ao público). 
Independente da classificação adotada, o que é comum nesses estudos é a compreensão do termo telecentro comunitário como um local que vai além da disponibilização de ferramentas de tecnologias da informação e comunicação. Os autores apresentam este equipamento como espaço de crescimento, participação e construção da cidadania.

Estudo realizado pela Rede de Informação do Terceiro Setor (Rits) (SELAIMEN, 2004) listou alguns dados sobre o perfil desses usuários dos telecentros dispersos na cidade de São Paulo. Segundo este estudo, pessoas de diversas faixas etárias freqüentam esses equipamentos, com destaque para a faixa dos 10 a 17 anos, como mostra a Ilustração 10.

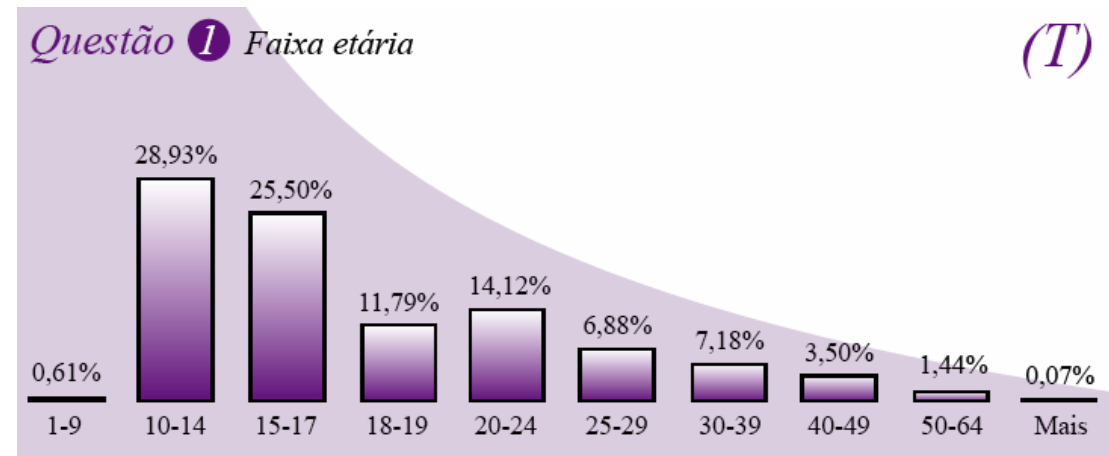

Ilustraç̃o 10: Faixa Etária dos usuários de telecentro em São Paulo ${ }^{42}$.

A pesquisa também aponta que $63,13 \%$ dos usuários entrevistados consideram o telecentro importante para a sua vida e $66,69 \%$ deles freqüenta o telecentro de 1 a 5 vezes por semana (Idem).

Esse tipo de levantamento demonstra a importância de um equipamento como o telecentro uma vez que ele possibilita, segundo os próprios usuários, mais do que inclusão digital, como mostra a Ilustração 11.

\footnotetext{
${ }^{42}$ FONTE: SELAIMEN, G. B. (coord.) Apropriação cidadã dos telecentros de São Paulo: um levantamento social. São Paulo: Rits, 2004.
} 


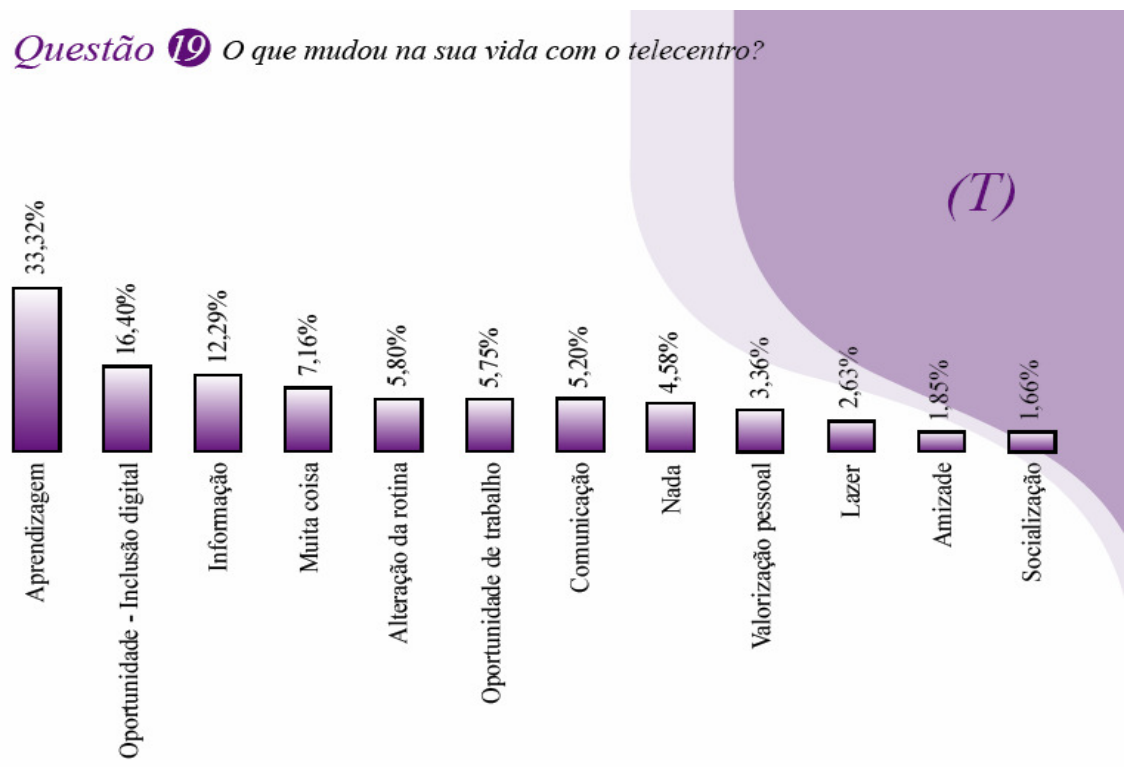

Ilustração 11: $O$ que o telecentro mudou na sua vida ${ }^{43}$.

A pesquisa apenas apresenta as respostas mais comuns à pergunta $O$ que mudou na sua vida com o telecentro? e não oferece uma especificação de cada um dos itens. Estes indicadores, porém, possibilitam a percepção dos telecentros como espaços de inclusão digital que também contribuem para o desenvolvimento local de suas comunidades, uma vez que oferecem mais do que acesso aos meios digitais: ampliam o acesso ao conhecimento, fortalecem as iniciativas locais e possibilitam a construção de novos conhecimentos.

Notando que a resposta mais comum da Ilustração 11 é Aprendizagem (33,32\%), torna-se importante investigar os tipos de conteúdos possíveis de serem aprendidos no espaço do telecentro, por isso, foi sobre esta análise que a presente pesquisa pretendeu se ocupar.

\footnotetext{
${ }^{43}$ FONTE: SELAIMEN, G. B. (coord.) Apropriação cidadã dos telecentros de São Paulo: um levantamento social. São Paulo: Rits, 2004.
} 


\section{Cultura, Comunicação e Ensino na sociedade informacional ${ }^{44}$}

O ser humano é produtor de conhecimentos e por isso produtor de cultura. Segundo Gohn,

no senso comum, o termo é associado a estudo-educaçãoescolaridade, ou ao mundo das artes, aos meios de comunicação de massa; ao mundo do folclore, lendas, crenças e tradições passadas ou, ainda a períodos ou etapas da civilização humana. (GOHN, 2005, p. 22).

O termo cultura vem do latim colore, que significa cultivo, cuidado. Está relacionado à prática do cultivo da terra e os conhecimentos da agricultura. Nas antigas civilizações, esse conhecimento era algo que enobrecia o homem (idem).

Ao longo dos anos, muitos estudiosos dedicaram seus esforços na tentativa de compreender melhor o termo cultura e seus processos na humanidade. Neste estudo, considero Cultura como produção humana, que engloba as conquistas históricas, desenvolvimento de produtos, tecnologia, teorias do pensamento e relações sociais de certo povo e/ou sociedade.

Para muitos autores, a definição de cultura não é um problema tão grande quanto a discussão sobre seu processo de transmissão e aquisição dela. Segundo Santos (1983), a aquisição da cultura representa a superação da desigualdade e a redução de relações de opressão entre sociedades e pessoas.

É uma realidade e uma concepção que precisam ser apropriadas em favor do progresso social e da liberdade, em favor da luta contra a exploração de uma parte da sociedade por outra, em favor da superação da opressão e da desigualdade. (1983, apud GOHN, 2005, p. 32)

O processo de absorção, reelaboração e transformação da cultura existente de um povo é chamado de Educação (GOHN, 2005 p. 98). A palavra educação vem do latim educere

Educare, no latim, era um verbo que tinha o sentido de "criar (uma criança), nutrir, fazer crescer. Etimologicamente, poderíamos afirmar que educação, do verbo educar, significa "trazer à luz a idéia" ou filosoficamente fazer a criança passar da potência ao ato, da virtualidade à realidade. (MARTINS, 2005)

44 O termo Sociedade da Informação, segundo Castells (1999a, p. 64), "enfatiza o papel da informação na sociedade", ao contrário, o termo "informacional indica o atributo de uma forma específica de organização social em que a geração, o processamento e a transmissão da informação tornam-se as fontes fundamentais de produtividade e poder devido às novas condições tecnológicas surgidas nesse período histórico". Considerando as definições deste autor, optei pela utilização do termo informacional, entendendo-o como um conceito mais amplo que permite compreender a sociedade em todos seus aspectos (produtora, usuária e transformadora da tecnologia existente). 
A escola e seus mecanismos de avaliação e validação (diplomas, certificados) é uma das principais instituições responsáveis pela apropriação da cultura por parte das novas gerações. Nessas instituições, o processo de educação foi sistematizado no ato de ensinar - ação que acontece por meio da instrução e pressupõe um educador que transmite as informações e conhecimentos aos educandos. As escolas foram legitimadas como a principal responsável pela educação em todo o mundo e hoje, no Brasil, é tida como direito do cidadão e dever do Estado (Lei Federal, ${ }^{\circ}$ 9.394/96).

Alguns autores como Bourdieu, porém, consideram o processo de aquisição da cultura como algo que acontece além dos muros da escola e não necessariamente ocorre pelo ato de ensinar. Segundo, Setton (2005), o autor

\begin{abstract}
distinguiu dois tipos de aprendizado; de um lado, o aprendizado precoce e insensível, efetuado desde a primeira infância, no ambiente familiar, podendo ou não ser prolongado por um aprendizado escolar que o pressupõe e o complementa; de outro, o aprendizado tardio, metódico, adquirido fora da família, nas instituições de ensino ou em outras esferas informais da educação. (SETTON, 2005, p. 79)
\end{abstract}

Compreender os diferentes processos de aquisição da cultura e educação é muito importante, pois eles apontam a verdade de que cultura não é sinônimo de um saber acadêmico e profissional. Cultura é um conjunto de saberes e modos de atuação do homem na história que estão em constante processo de transformação.

Quando nos deparamos com as transformações do nosso tempo, citadas no capítulo 1, podemos compreender que as tecnologias fazem parte de uma nova cultura e é preciso considerar as afirmações de Lévy (1993) de que "nenhuma reflexão séria sobre o devir da cultura contemporânea pode ignorar a enorme incidência das mídias eletrônicas (sobretudo a televisão) e da informática" (LÉVY, 1993, p.17), sendo necessário, portanto, adequar os processos de educação, pois:

Pedagogia e tecnologia (entendidas como processos sociais) sempre andaram de mãos dadas: o processo de socialização das novas gerações inclui necessária e logicamente a preparação de jovens indivíduos para o uso dos meios técnicos disponíveis na sociedade seja o arado seja o computador. (BELLONI, 2002).

\title{
3.1. Tecnologias como fonte de informação e Educação
}

Nas sociedades contemporâneas, as pessoas recebem informações e formam sua própria opinião política essencialmente por intermédio da mídia, e principalmente da televisão. (CASTELLS, 1999b, p. 370). 
Como seres sociais, desde pequenos, somos estimulados a nos comunicar uns com os outros. O choro do bebê e os gestos já são os primeiros indícios dessa nossa necessidade de comunicação. Por dependermos uns dos outros é que necessitamos nos comunicar.

As sociedades se desenvolveram, as necessidades se transformaram e, conseqüentemente, foram criadas novas e diferentes formas de comunicação. Com o surgimento da escrita (também advinda da necessidade da comunicação humana), os meios de comunicação se aprimoraram até que chegassem ao que atualmente encontramos: uma grande variedade de formas comunicativas que reúnem sons, imagens, textos e interatividade.

Os meios de comunicação foram criados como extensões do corpo humano, na tentativa de ampliar sua capacidade de comunicação. A etimologia das palavras televisão, telefone, telégrafo nos indica isso, já que o prefixo tele (do grego) significa longe (FARACO, MOURA, 1995, p.122). Assim, televisão é um aparelho que possibilita a visão de algo mesmo que distante; o telefone é aquele aparelho que projeta a voz e possibilita falar com alguém mesmo não estando próximo a ele e assim por diante.

Esse tipo de extensão da comunicação permitiu ao ser humano o desenvolvimento de outros mecanismos de comunicação. Se antes só podíamos nos comunicar com outra pessoa, hoje esses meios possibilitam a comunicação em grande escala: são os chamados meios de comunicação de massa.

Os meios de comunicação de massa têm gerado algumas discussões em torno do seu potencial para educação, uma vez que se tornam, cada vez mais, um importante elemento de difusão da informação na sociedade. Como afirma Castells (1999b), eles possuem forte impacto na vida das pessoas, sendo inclusive caracterizados como meios formadores de opinião, interferindo até no cenário político, uma vez que podem exercer grande influência nas decisões públicas e políticas da sociedade.

\footnotetext{
em virtude dos efeitos convergentes da crise dos sistemas políticos tradicionais e do grau de penetrabilidade bem maior dos novos meios de comunicação, a comunicação e as informações políticas são capturadas essencialmente no espaço da mídia. Tudo o que fica de fora do alcance da mídia assume a condição de marginalidade política. (CASTELLS, 1999b)
}

Afonso (2004) reforça essa capacidade de educação dos meios de comunicação de massa, situando-os entre os veículos de educação não-formal. 
não podemos deixar de considerar que há outros processos em curso que, com lógicas muitos distintas, procuram ocupar o amplo espaço da educação não-escolar (...) O exemplo mais actual, que pode ajudar a entender o que acabo de afirmar, diz respeito ao facto de a educação não-formal estar a ser fortemente conotada com os efeitos educativos dos meios de comunicação de massa, ou estar a ganhar uma centralidade crescente em diferentes contextos de trabalho (AFONSO, 2004, p. 33) ${ }^{45}$

Outros autores também percebem a importância dos meios de comunicação em massa na educação e/ou transmissão cultural. Em seu estudo Um novo capital cultural: pré-disposições e disposições à cultura informal nos segmentos com baixa escolaridade, Maria da Graça Setton (2005) aborda a questão do capital cultural definido por Pierre Bourdieu e, na tentativa de explicar o sucesso escolar de alguns alunos provenientes de famílias não muito privilegiadas e de classes econômicas baixas, se propôs a trabalhar a hipótese de que outras formas de educação estão presentes nas trajetórias acadêmicas dos alunos investigados. Ela conclui que

o acesso informal midiático, em ambientes familiares dóceis à cultura escolar, ampliou o referencial cultural dos alunos (...) ficou evidente a familiaridade de todos com o material posto à disposição pela cultura das mídias. (SETTON, 2005, p. 90).

Este estudo reforça a hipótese de que os meios de comunicação têm potencial tanto para o ensino quanto para a Educação, nos termos acima definidos. Este potencial é percebido, quando notamos a velocidade com que as informações se modificam na atualidade e a grande integração mundial, o que faz com que os veículos de comunicação assumam papel ainda mais importante. São eles que transmitem em tempo quase real o que acontece pelo mundo, trazendo informação e conhecimento às pessoas.

Existem muitos meios de comunicação que, espontânea ou intencionalmente exercem um papel educativo na vida das pessoas. Em meios como livro didático, jornal, revista talvez fique mais fácil de perceber esse caráter educativo devido à linguagem escrita, que é a forma mais tradicional de difusão da informação de massa, mas não são apenas esses meios de comunicação que educam.

Se considerarmos a Internet (Rede Mundial de Computadores) como um dos principais meios de comunicação na nossa sociedade, podemos identificar que ela possui algumas peculiaridades, pois é um dos únicos veículos que permitem a comunicação em quatro níveis diferentes: comunicação interpessoal (entre uma pessoa e outra), comunicação em grupo (de uma pessoa/veículo a um determinado grupo de pessoas), comunicação de massa (de um determinado

\footnotetext{
${ }^{45}$ texto mantido conforme original do autor, em português de Portugal
} 
veículo para uma grande parcela da população) e comunicação intrapessoal (de uma pessoa consigo mesma).

A ilustração 12 permite observar que este meio de comunicação é bastante versátil e, ao mesmo tempo em que possibilita a comunicação em diferentes níveis, utiliza-se de diferentes linguagens para isso: imagem, texto e som. Ela é o único meio de comunicação que aparece em todos os cruzamentos do quadro, o que lhe confere uma grande importância na nossa sociedade, onde a comunicação e a busca pela informação são cada vez mais essenciais.

\begin{tabular}{|c|c|c|c|c|}
\hline & $\begin{array}{c}\text { Comunicação em } \\
\text { Grupo }\end{array}$ & $\begin{array}{c}\text { Comunicação de } \\
\text { Massa }\end{array}$ & $\begin{array}{l}\text { Comunicação } \\
\text { Interpessoal }\end{array}$ & Comunicação Intrapessoal \\
\hline \multirow{6}{*}{$\begin{array}{l}\text { Imagem } \\
\text { (fixa / } \\
\text { móvel) }\end{array}$} & TV & TV & DESENHO & \multirow{6}{*}{$\begin{array}{c}\text { TV } \\
\text { REVISTA } \\
\text { CARTAZ } \\
\text { CINEMA } \\
\text { CARTA } \\
\text { INTERNET }\end{array}$} \\
\hline & REVISTA & REVISTA & \multirow[t]{5}{*}{ INTERNET } & \\
\hline & CARTAZ & CARTAZ & & \\
\hline & INTERNET & CINEMA & & \\
\hline & & INTERNET & & \\
\hline & & & & \\
\hline \multirow{6}{*}{ Texto } & TV & TV & CARTA & \multirow{6}{*}{$\begin{array}{c}\text { TV } \\
\text { REVISTA } \\
\text { CARTAZ } \\
\text { CINEMA } \\
\text { TELEGRAMA } \\
\text { CARTA } \\
\text { INTERNET } \\
\end{array}$} \\
\hline & REVISTA & REVISTA & TELEGRAMA & \\
\hline & CARTAZ & CARTAZ & INTERNET & \\
\hline & INTERNET & CINEMA & & \\
\hline & & INTERNET & & \\
\hline & & & & \\
\hline \multirow{5}{*}{ Som } & TV & TV & TELEFONE & \multirow{5}{*}{$\begin{array}{c}\text { TV } \\
\text { RÁDIO } \\
\text { TELEFONE } \\
\text { CINEMA } \\
\text { INTERNET }\end{array}$} \\
\hline & RÁDIO & RÁDIO & INTERNET & \\
\hline & INTERNET & CINEMA & & \\
\hline & & INTERNET & & \\
\hline & & & & \\
\hline
\end{tabular}

Ilustracão 12: Tipos de Comunicação X Linguagens Utilizadas. ${ }^{46}$.

A ilustração 13 mostra exemplos de ferramentas da Internet onde é possível verificar os cruzamentos entre os níveis de comunicação e as linguagens citados.

46 FONTE: MATUDA, F.G.. Características, peculiaridades e funções dos meios de comunicação: Internet. - Trabalho apresentado na disciplina de pós-graduação "CTR 5011 - Tecnologia Educacional e Comunicação em Som e Imagem" (ECA- USP), no $2^{\circ}$ semestre de 2006. 


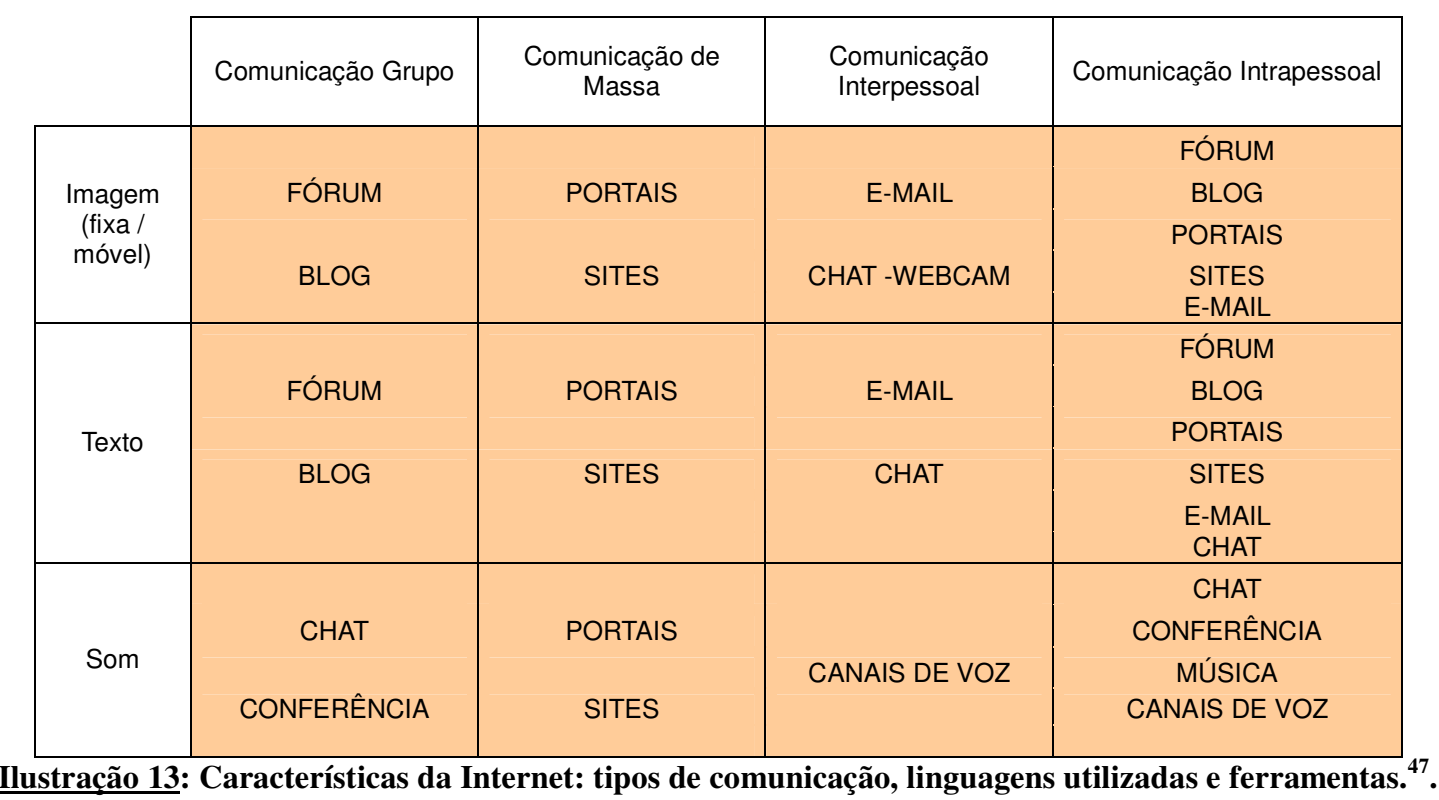

Como meio bastante versátil, a Internet reúne outros meios de comunicação (televisão, rádio, cartaz, canal de voz - que funcionam de forma semelhante ao telefone, jornal, revista etc) e este é um processo muito importante na revolução tecnológica: "a crescente convergência de tecnologias específicas para um sistema altamente integrado, no qual trajetórias tecnológicas antigas ficam literalmente impossíveis de se distinguir em separado" (CASTELLS, 1999a, p. 109, grifo do autor). Essa característica da revolução tecnológica, em específico da Internet, desmonta teorias que defendem a extinção de meios tecnológicos antigos com o surgimento de novas tecnologias e reforça a idéia de incorporação dos conhecimentos produzidos anteriormente pelo homem, como citado no Capítulo 1.

Além de convergir outras tecnologias em seu espaço e de se utilizar de diferentes linguagens para a veiculação da informação, a Internet possui ainda um recurso específico: o hipertexto ${ }^{48}$. Este tipo de texto não exclui os sons e as imagens, mas se caracteriza pela oposição aos textos lineares. Segundo Trevisan (2005, p. 16), "na narrativa hipertextual, o autor oferece múltiplas possibilidades através das quais os próprios leitores constroem sucessões temporais e escolhem personagens,

47 FONTE: MATUDA, F.G.. Características, peculiaridades e funções dos meios de comunicação: Internet. - Trabalho apresentado na disciplina de pós-graduação "CTR 5011 - Tecnologia Educacional e Comunicação em Som e Imagem" (ECA- USP), no $2^{\circ}$ semestre de 2006.

48 "Tecnicamente, um hipertexto é um conjunto de nós ligados por conexões. Os nós podem ser palavras, páginas, imagens, gráficos ou parte de gráficos, seqüências sonoras, documentos complexos que podem eles mesmo ser hipertextos. os itens de informação não são ligados linearmente, como em uma corda com nós, mas cada um deles, ou a maioria, estende suas conexões em estrela, de modo reticular. Navegar em um hipertexto significa portanto desenhar um percurso em uma rede que pode ser tão complicada quanto possível. Porque cada nó pode, por sua vez, conter uma rede inteira." (LÉVY, 1993, p.33) 
realizando saltos com base em informações referenciais".

Para Lévy (1996) o hipertexto, além de possibilitar interação entre leitor e autor, proporcionou um novo tipo de comunicação, onde o navegador também se forma como um autor de conhecimentos.

\begin{abstract}
Assim a escrita e a leitura trocam de papéis. Todo aquele que participa da estruturação do hipertexto, do traçado pontilhado das possíveis dobras de sentido, já é um leitor. Simetricamente, quem atualiza um percurso ou manifesta este ou aquele aspecto da reserva documental contribui para a redação, conclui momentaneamente uma escrita interminável. As costuras e remissões, os caminhos de sentido originais que o leitor inventa podem ser incorporados à estrutura mesma do corpus. A partir do hipertexto, toda leitura tornou-se um ato de escrita. (LÉVY, 1996, p. 46).
\end{abstract}

Castells (2006) também aponta o hipertexto como um importante elemento da comunicação pela Internet "Os textos eletrônicos permitem flexibilidade de feedback, interação e reconfiguração de texto muito maiores (...) e, desse modo, alteram o próprio processo de comunicação." (CASTELLS, 1999a, p.114).

O hipertexto possibilita a comunicação em diferentes tempos e espaços e possibilita a troca de informações diferenciada, não preestabelecida e em constante construção. Ele talvez seja a principal característica da Internet para a Educação, uma vez que permite a troca de conhecimentos na rede, tornando os usuários educandos e ao mesmo tempo educadores.

Diante desse potencial comunicativo e das suas influências na vida social no nosso tempo, é preciso considerar a afirmação de Silveira de que "Educar é cada vez mais mergulhar na fronteira virtual" (SILVEIRA, 2001, p. 28) e é inevitável que, ao pensarmos em um projeto de educação, não pensamos também em um projeto que inclua as novas tecnologias. Educação e tecnologia são processos em construção, sendo um determinante do outro e ambos essenciais na construção da sociedade da informação.

É a educação o elemento-chave para a construção de uma sociedade da informação e condição essencial para que pessoas e organizações estejam aptas a lidar com o novo, a criar e, assim, a garantir seu espaço de liberdade e autonomia. (TAKAHASHI, 2000).

Sendo a Educação um dos principais mecanismos de troca de informações e transmissão intergeracional da cultura e, considerando que as tecnologias são essenciais para que isso aconteça, insistir em ignorar a relação entre educação e tecnologia pode ser o reforço do apartheid digital. Afinal, como afirma Silveira (2001), na sociedade da informação, quem não souber manipular os meios tecnológicos ficará cada vez mais distante da produção de conhecimento e, estagnado, 
agravará sua condição de miséria. Garantir o acesso às tecnologias é possibilitar acesso à informação e apropriação dos meios de comunicação, o que permite ao cidadão uma autonomia no seu processo de desenvolvimento.

As novas tecnologias da informação e da comunicação podem ser aplicadas na Educação de diferentes formas, dependendo dos objetivos para os quais elas são utilizadas. Os meios de comunicação estão sendo usados como apoio ao ensino escolar, como recurso para a modalidade de Educação à distância, em espaços de Educação Social e também podem ser usados como recurso de educação informal ou familiar.

\subsubsection{Tecnologias como apoio ao ensino escolar}

Desde sua criação como instituição de ensino, as escolas têm por objetivo educar os cidadãos, transmitindo-lhes conhecimentos e valores que a sociedade, na qual ele está inserido, julga pertinentes à sua formação.

Por muito tempo se acreditou que o conhecimento estava na pessoa do professor (transmissor da informação) e, por isso, as práticas escolares foram pautadas basicamente por aulas expositivas. As aulas dadas nas instituições de ensino costumavam reforçar o que Paulo Freire (1987) chamava de Educação bancária, cujo

trabalho será, também, o de imitar o mundo. O de ordenar o que já se faz espontaneamente. $\mathrm{O}$ de 'encher' os educandos de conteúdos. É o de fazer depósitos, de 'comunicados' - falso saber - que ele considera como verdadeiro saber. (FREIRE, 1987, p. 63).

Embora a estrutura escolar não tenha se modificado muito nos últimos tempos, estudos nas áreas da Educação e da Psicologia do Desenvolvimento apresentam novas abordagens de ensino, considerando que aprendemos de formas diversas e na interação de uns com os outros e com o meio.

Influenciados pelo movimento escolanovista ${ }^{49}$, na década de 30 , pelos estudos de teóricos como Paulo Freire em meados dos anos 70 e 80 e pelas teorias da Psicologia do Desenvolvimento aplicadas ao campo da Educação (Piaget e Vygotsky), os discursos educacionais, em todo o mundo,

49 O movimento escolanovista que surgiu no século XIX, na Europa e nos Estados Unidos. Este movimento opunha-se às práticas pedagógicas tidas como tradicionais e visava uma educação que pudesse integrar o indivíduo na sociedade, garantindo o acesso de todos à escola. No Brasil, o escolanovismo foi marcado pela assinatura do Manifesto dos Pioneiros da Educação Nova, em 1932, que representou um divisor de águas entre educadores progressistas e conservadores. Um dos principais representantes deste movimento no Brasil foi Anísio Teixeira. 
passaram a considerar novas formas de abordagem dos conteúdos nas escolas.

Segundo Belloni (2002),

As novas gerações estão desenvolvendo novos modos de perceber (sintéticos e gestaltianos em contraposição aos modos analíticos e seqüenciais trabalhados na escola), novos modos de aprender mais autônomos e assistemáticos (autodidaxia), voltados para a construção de um conhecimento mais ligado à experiência concreta (real ou virtual), em contraposição à transmissão bancária de conhecimentos abstratos, freqüentemente praticados na escola. (BELLONI, 2002).

Assim, reconhecendo que a Educação deve considerar seu contexto social e também as transformações de cada tempo e espaço, a presença das tecnologias da informação e comunicação na escola tem sido cada vez mais notada, já que, em uma sociedade em que as tecnologias da comunicação estão presentes nas relações e nas atividades cotidianas, ignorá-las neste espaço seria ignorar a realidade dos educandos.

Basicamente, os recursos tecnológicos são utilizados nas escolas de três maneiras:

a) como recurso audiovisual nas aulas:

Aparelhos de som e vídeo, rádio, televisão e salas de informática são utilizados como complemento às aulas e/ou como estratégia para tornar o conteúdo mais interessante e mais próximo da linguagem dos alunos. Muitos professores fazem uso desses recursos para tornar as aulas mais dinâmicas e assim atingir melhor desempenho por parte dos alunos.

Embora possam ser úteis, são apenas meios; data show, por exemplo não melhora a conferência, apenas pode torná-la menos maçante, oferecer roteiro para seu desenvolvimento, chamar a atenção dos ouvintes, retardar o natural desligamento de quem fica ouvindo por longo tempo. (DEMO, 2004, p. 37)

\section{b) como fonte de pesquisa:}

As novas tecnologias se apresentam também como um apoio ou recurso da educação formal e escolar uma vez que, semelhantemente ao livro didático e outros livros, elas se apresentam como fonte de conteúdos e saberes. Os recursos tecnológicos são uma rica fonte de pesquisa e informação para os alunos. Pesquisas por meio da Internet são cada vez mais comuns já que ela possibilita uma infinidade de caminhos para a busca da informação.

c) como instrumento de aprendizagem em informática: 
As salas de informática se constituem em um espaço de aprendizagem nas escolas. Sua implantação tinha como objetivo, além de possibilitar a busca de informação dos alunos por meio desses recursos, possibilitar o acesso dos educandos aos recursos tecnológicos, sendo possível o desenvolvimento de habilidades e competências para os diferentes usos que eles possibilitam.

Apesar da relevância e pertinência dessas três possibilidades de uso dos recursos tecnológicos nas escolas, não podemos deixar de levantar algumas questões que se apresentam diante dessa abordagem.

Há cinco mil anos a prática escolar "se baseia no falar/ditar do mestre, na escrita manuscrita do aluno e, há quatro séculos, em um uso moderado da impressão" (LÉVY, 1999, p. 09). Para Lévy, a integração da informática e do audiovisual na escola supõe "o abandono de um hábito antropológico mais que milenar, o que não pode ser feito em alguns anos".

Segundo Belloni, as instituições não estão preparadas para o trabalho com as tecnologias.

a escola (principalmente a pública) não consegue atender
minimamente a demandas cada vez maiores e mais exigentes e a
'academia' entrincheira-se em concepções idealistas,
negligenciando os recursos técnicos, considerados como
meramente instrumentais. No setor privado, as escolas respondem
'naturalmente' aos apelos sedutores do mercado e se entregam de
corpo e alma à inovação tecnológica, sem muita reflexão, crítica e
bem pouca criatividade, formando não o usuário competente e
criativo, como seria desejável, mas o consumidor deslumbrado.
(BELLONI, 2002)

Nem todas as instituições têm acesso aos recursos tecnológicos e as que possuem nem sempre fazem uso adequado. Apesar dos esforços do governo quanto à disponibilização de tecnologias nas escolas, ainda existe no Brasil, unidades escolares desprovidas de elementos básicos como mobiliário adequado e instalação elétrica. Muitas instituições ainda demorarão a conhecer os recursos tecnológicos no seu processo de ensino-aprendizagem.

Além da desigualdade de acesso aos recursos, enfrentamos um despreparo dos professores para a utilização das tecnologias nas salas de aula. Os cursos de formação não abordam com prioridade esse tipo de trabalho, as instituições de ensino não possuem especialistas na área tecnológica e muitas vezes, o uso que se faz dos equipamentos não explora todo o potencial que eles oferecem para a Educação.

Para essa questão, podemos apontar duas possibilidades: a primeira diz respeito à cobrança da comunidade escolar para melhoria dos programas de implantação dos recursos na escola, levando em consideração a importância não só do acesso como também da formação dos 
professores para a utilização das ferramentas. A segunda diz respeito a uma forma de aprendizagem que valoriza a interação entre educador-educando e amplia a troca de saberes. O educador, neste caso, pode também se transformar em um aprendiz na interação com os saberes de seus educandos nativos da era digital e midiática, buscando uma nova relação de aprendizagem - "Quem ensina aprende ao ensinar e quem aprende ensina ao aprender." (FREIRE, 1996).

É preciso que as escolas façam uso das tecnologias de diferentes maneiras, explorando-as ao máximo como recurso de apoio ao ensino e como instrumentos de crescimento por parte dos educandos, que podem utilizar os recursos para se tornarem não apenas leitores como produtores de conhecimento. Esse tipo de trabalho só será possível quando as instituições e profissionais tiverem a clareza de que: "não basta levar computadores para as escolas. É preciso discutir seu uso didáticopedagógico e buscar incorporá-los ao processo de ensino e aprendizagem”. (SILVEIRA, 2001, p. $33)$.

\subsubsection{Tecnologias na Educação à distância}

O direito à educação é hoje reconhecido como um dos direitos fundamentais do homem e é considerado na legislação de praticamente todos os países. (OLIVEIRA, 2001).

Apesar da veracidade da afirmativa de Oliveira, o acesso aos diferentes níveis de Educação não é garantido a todas as pessoas. No Brasil, por exemplo, é possível verificar que boa parte da população não freqüenta a escola básica (ainda que ela seja obrigatória e estabelecida por lei) e aqueles estudantes que chegam a completar sua formação, neste nível, criam uma grande demanda que a estrutura universitária do país não consegue atender por completo.

Dentre as dificuldades que as universidades brasileiras enfrentam é possível destacar: i) a presença de um contingente grande de estudantes; ii) custos financeiros elevados para expansão e melhoria das universidades existentes; iii) necessidade urgente de recursos para cobrir solicitações de pesquisadores; iv) aperfeiçoar e qualificar os docentes e; v) dificuldades para levantar recursos financeiros para se adequar às novas demandas sociais, científicas e tecnológicas (MARTINS, 1991).

Neste cenário, as novas tecnologias se apresentam como uma solução possível para: atender a demanda existente; possibilitar programas de aperfeiçoamento profissional e também atender aqueles que não puderam freqüentar a educação básica no período adequado.

É a partir da percepção de que as tecnologias auxiliam na propagação da informação, 
ampliando as possibilidades da educação e considerando afirmações como as de Carvalho de que "Educar não é específico do professor ou da escola" (CARVALHO, 2004), surgem experiências de Ensino diferenciadas como a Educação à distância.

Almeida (2003) afirma que existem autores que estudam a EaD (Educação a Distância) sob diversos ângulos, dizendo que alguns se embasam nas características comunicacionais, outros na organização curricular dos cursos, na questão da separação física entre alunos e professores e há aqueles que se dedicam a estudar os suportes utilizados. Para o autor, as tecnologias podem ser utilizadas nesta modalidade de ensino "tanto na tentativa de simular a educação presencial com o uso de uma nova mídia como para criar novas possibilidades de aprendizagem por meio da exploração das características inerentes às tecnologias empregadas" (ALMEIDA, 2003).

No Brasil, este tipo de educação está regulamentada pela Lei de Diretrizes e Bases da Educação Nacional (Lei n⿳ำ 9.394/96), pelo Decreto n. $^{\circ}$ 5.622, publicado no D.O.U. de 20/12/05 e o Decreto n. ${ }^{\circ} 2.561$, de 27 de abril de 1998) com normatização definida na Portaria Ministerial ${ }^{\circ}$ 4.361, de 2004.

Segundo o art. 30 do Decreto $\mathrm{n}^{\circ}$. 5.622/05, na Educação básica, a oferta de educação a distância é permitida exclusivamente para complementação da aprendizagem ou em situações emergenciais. Nos demais níveis, desde que assegurados os Indicadores de qualidade para cursos de graduação à distância e autorizados pelos devidos Conselhos de Educação, os cursos a distância são permitidos e podem inclusive emitir certificação.

Os primeiros cursos a distância, realizados por instituições privadas como o Instituto Universal Brasileiro, tinham o objetivo de atender emergencialmente as pessoas que não puderam freqüentar a escola na idade adequada (Educação de Jovens e Adultos). Eles eram feitos por correspondência e foram se aprimorando ao longo do tempo.

Com o desenvolvimento dos meios de comunicação e das novas mídias, novas formas de Educação à distância também surgiram. Um forte exemplo disso foi o Programa da Fundação Roberto Marinho que, com repasse de verbas públicas destinadas à Educação, desenvolveu o Telecurso 2000, que fazia uso de vídeo-aulas (veiculadas pela televisão) e material impresso para formar turmas de Ensino Básico e também profissionalizante.

Os cursos de aprimoramento para professores, desenvolvidos pelos governos federal e estaduais, na década de 90, também fizeram uso da televisão como meio de EaD. Exemplos desse tipo de programa de formação continuada são o projeto Um salto para o Futuro (1991) e a TV Escola (1996).

Segundo Belloni (2002), este tipo de programa não deu muitos resultados porque estão 
imbuídos de interesses políticos e tecnológicos, sem se preocupar de fato com a aprendizagem por parte dos educandos. Para a autora, este tipo de educação privilegia justamente aqueles que têm maior facilidade em lidar com as tecnologias, "ao passo que aqueles que mais necessitam de reforços em sua formação não têm condições para aproveitá-las".

Apesar das críticas e das experiências não muito satisfatórias, com o desenvolvimento da Internet, os cursos de Educação à distância foram se aprimorando, já que a rede mundial de computadores torna possível a comunicação e a troca de informações com maior rapidez, sem fronteiras e com baixo custo, se comparada à produção das vídeos-aula.

Com essa nova TIC, os espaços e tempos de aprendizagem se transformam: o espaço virtual é diferente do espaço físico e o tempo virtual é diferente do tempo físico também.

não se pode mais considerar uma única extensão ou uma cronologia uniforme, mas uma quantidade de tipos de espacialidades e de duração. Cada forma de vida inventa seu mundo [...] e, com esse mundo, um espaço e um tempo específicos. [...]. (LÉVY, 1996, p. 22-3)

Os novos espaços constituídos na rede mundial de computadores permitiram uma aproximação das pessoas ainda que o espaço físico permaneça diferente. Isso porque, como já citado no item anterior, essa imensa rede possui um fator importantíssimo que a construção de hipertextos.

Falar da separação professor-aluno parece óbvio, mas é preciso entender o significado desta expressão na EaD. Estar distante do professor não significa a mesma coisa que um professor distante $\mathrm{e}$ é justamente esta uma das maiores preocupações das instituições que lidam com esta modalidade de ensino. A percepção da distância física/geográfica não deve atrapalhar o aprendizado do aluno, muito menos a percepção da distância psicológica. (FIUZA, 2002)

Os hipertextos e a convergência de diferentes mídias em um único veículo (a Internet) possibilitam maior troca e interatividade entre os educandos e os conteúdos. Aproximando o educador do educando, por diversos meios de comunicação (fórum, chat, correio eletrônico), cada um pode estabelecer seu tempo de estudo e a seqüência de conteúdos, mas é preciso considerar que 
apesar das possibilidades do aprendiz desenvolver a leitura e a escrita com o uso de hipertextos, escolhendo entre um leque de ligações preestabelecidas ou criando novas ligações e percursos não previstos (...), a exploração de hipertextos não dá conta da complexidade dos processos educacionais, cujas atividades se desenvolvem com o uso desses materiais de suporte e, sobretudo, com a interação entre os alunos e entre estes e os formadores, que na EaD pode ser o professor ou o tutor. (ALMEIDA, 2003)

Devido à complexidade da construção de ambientes de $\mathrm{EaD}$, algumas universidades fundaram núcleos de estudos para o desenvolvimento de plataformas como o Col (Cursos On-line), desenvolvido pelo LARC - EPUSP (Laboratório de Arquitetura e Redes de Computadores da Escola Politécnica - Universidade de São Paulo) e o Teleduc, desenvolvido pelo Núcleo de Informática Aplicada à Educação (Nied) e Instituto de Computação (IC) da Universidade Estadual de Campinas (Unicamp).

Ainda que muitos os programas de EaD levantem questões e críticas, eles podem ser utilizados para diminuir as barreiras de acesso de grande parte da população à Educação Superior.

Iniciativas neste sentido têm sido concebidas como a UAB (Universidade Aberta Brasil) desenvolvida pelo Ministério da Educação (MEC) em 2005.

O Sistema Universidade Aberta do Brasil (UAB) tem como prioridade a formação de professores para a Educação Básica. Para atingir este objetivo central a UAB realiza ampla articulação entre instituições públicas de ensino superior, estados e municípios brasileiros, para promover, através da metodologia da educação a distância, acesso ao ensino superior para camadas da população que estão excluídas do processo educacional. ${ }^{50}$

O Sistema UAB tem como objetivo formar um projeto integrado de instituições públicas para, por meio da $\mathrm{EaD}$, levar o ensino superior até municípios brasileiros que não contam com oferta ou cujos cursos ofertados são insuficientes para atender à população.

Outra iniciativa, mais recente, é a Univesp (Universidade Virtual do Estado de São Paulo). Conforme denomina a Secretaria do Ensino Superior do Governo do Estado de São Paulo,

O PROGRAMA UNIVESP vem atender a preceito do Plano Nacional de Educação, instituído pela Lei federal $\mathrm{n}^{\circ} 10.172$, de 2001, que em seu item 6.2 afirma ser preciso ampliar o conceito de educação à distância para poder incorporar todas as possibilidades que as tecnologias de comunicação possam propiciar a todos os níveis e modalidades de educação. ${ }^{51}$

50 Disponível no Portal Oficial do Ministério da Educação <http://portal.mec.gov.br/seed> Acesso em set/2008.

51 Disponível no website da Secretaria do Ensino Superior do Governo do Estado de São Paulo. $<$ http://www.ensinosuperior.sp.gov.br/portal.php/univesp> Acesso em set/2008. 
O programa prevê a oferta de 6.600 vagas para estudantes no ano de 2009. Essas vagas serão oferecidas pela Unesp (Curso de Pedagogia) e USP (Curso de Pedagogia, Licenciatura em Biologia e Ciências), que utilizarão a tecnologia da TV digital e de ambientes virtuais de aprendizagem, desenvolvidos especialmente para este programa.

Não é objetivo desta pesquisa avaliar as iniciativas de EaD desenvolvidas no Brasil, mas pontuar que elas existem; estão em crescente desenvolvimento devido à demanda de estudantes e profissionais sem formação e podem ser utilizadas para diminuir barreiras sociais e de acesso ao conhecimento.

É preciso, contudo, pontuar a necessidade de se refletir nos programas desenvolvidos, lembrando que esta modalidade de ensino ainda é recente e as poucas experiências não permitem conclusões sobre sua metodologia, veículos e eficácia para uma aprendizagem significativa. Assim como abordado no Capítulo 1, quando discuto a questão da inclusão digital, é importante destacar que não basta oferecer acesso aos cursos de formação à distância se não forem trabalhadas outras necessitadas como alfabetização digital, acesso aos equipamentos tecnológicos etc. 


\section{Podem os programas de Inclusão Digital serem espaços de educação?}

Com base nas considerações e discussões traçadas nos capítulos anteriores, surge a reflexão sobre o potencial do telecentro como espaço de ensino e Educação, uma vez que:

I - as tecnologias são, cada vez mais, primordiais para a comunicação e transmissão da informação na nossa sociedade;

II - as tecnologias estão sendo incorporadas pelos processos de ensino e aprendizagem (escolar e a distância - item 3.2.);

III - o potencial das novas tecnologias para a comunicação (item 3.1.) permite a percepção quanto à existência de um aprendizado obtido na interação do usuário com a máquina e do usuário com outras pessoas na rede.

Se o telecentro comunitário se constitui em um programa de inclusão digital (item 2.6.) que visa disponibilizar o acesso às tecnologias por parte das camadas da população que de outra forma não teriam acesso a elas, podemos levantar o questionamento quanto à existência de relações de ensino e de Educação neste equipamento. No âmbito deste trabalho importa especificamente investigar se o telecentro pode ser considerado um espaço de Educação.

Para responder a essa pergunta, é necessário ampliar a compreensão da Educação, entendendo-a como um processo existente não apenas no espaço escolar, mas em outros setores da nossa sociedade.

\subsection{Educação também se faz fora da escola: requalificando os espaços da cidade}

Das necessidades do homem nasce o desenvolvimento de tecnologias, conhecimentos, modos de vida etc. Da interação entre os homens se faz educação, processo de aquisição e recriação do conhecimento produzido.

Com as novas tecnologias, a propagação da informação está cada vez mais rápida e alcança populações com maior intensidade. Essa realidade aponta para o fato de que "Educar não é específico do professor ou da escola, mas pode ser e é levado a cabo por várias outras instituições sociais" (CARVALHO, 2004).

Isso porque a construção e reconstrução do conhecimento não ocorrem apenas por meios formais, mas acontece na interação entre os seres humanos. Assim, é possível dizer que existe educação em outros espaços como a casa (na convivência familiar), a rua (na interação com os 
amigos) e até a Internet (na interação, ainda que virtual, entre os usuários da rede).

Acreditando neste princípio de que nós aprendemos em diferentes espaços e na interação com outras pessoas, em meados da década de 90, alguns países da América Latina, por meio de organizações sociais, iniciaram um movimento que deu origem à Carta das Cidades Educadoras ${ }^{52}$. Este documento defende a idéia de que a cidade, em todas as suas dimensões, oferece aos seus cidadãos várias formas de aprendizado.

(...) a cidade favorece a aprendizagem permanente de novas linguagens e oferece oportunidades para o conhecimento do mundo, o enriquecimento individual e a possibilidade de soluções solidárias. (...) desta maneira, além de suas funções tradicionais (econômica, social, política e de prestação de serviços), assume a intencionalidade e a responsabilidade na formação, promoção e desenvolvimento de todos os seus habitantes: crianças, jovens, adolescentes, adultos e idosos. (CABEZUDO, 2004, p. 12).

Uma cidade é considerada educadora "se oferece generosamente a seus habitantes, se deixa utilizar para seu crescimento e se os ensina a fazerem-se sujeitos e cidadãos" (idem, 2004, p. 12).

Grandes cidades como Porto Alegre, Montevidéu e São Paulo aderiram a este movimento, com o intuito de transformar o espaço urbano da pólis em um lugar de educação.

Para este estudo, é importante ressaltar a importância dada às tecnologias pela Carta das Cidades Educadoras, pois, entendendo que "a formação e a educação são possíveis a partir de muitos âmbitos da vida cotidiana” (BRARDA, RÍOS, 2004, p. 30) e que as tecnologias são cada vez mais essenciais na vida das pessoas hoje, o documento explicita que "é preciso providenciar entre outros, o acesso fácil de toda a população às tecnologias da informação e das comunicações que permitam o seu desenvolvimento”. (GENOVA, 2004).

O foco das cidades educadoras está justamente em garantir o desenvolvimento de seus cidadãos e para isso, como afirma Silva (2006), é preciso entender que:

A primeira questão objetiva que se coloca como desafio para uma cidade educadora tem a ver com a distribuição, uso e ocupação dos espaços urbanos e dos espaços públicos. Se concordarmos que a educação informal e não-formal acontecem, sobretudo, nos espaços públicos e coletivos, concluiremos que é preciso então requalificar esses espaços para que os potenciais educativos que possuem sejam colocados a serviço da população que deles precisa. (SILVA, 2006, p. 256).

\footnotetext{
${ }^{52}$ CARTA DAS CIDADES EDUCADORAS. Proposta definitiva, Genova, 2004. Disponível em: <http: www.cde.ua.pt/caipi/DOCU/cartadascidadeseducadoras.pdf > Acesso em: 10 mai 2006.
} 
Por perceber que práticas educativas fora dos muros escolares são cada vez mais freqüentes, assim como a aprendizagem por meio de ferramentas tecnológicas, concordo com os princípios das cidades educadoras e identifico neles duas questões essenciais para esta pesquisa: a importância de requalificar os espaços da cidade na busca por compreendê-los como espaços educativos e a percepção de que a educação é possível a partir das novas tecnologias, dado o seu valor na atualidade. Assim, devo também concordar com Gohn (2005) que afirma sobre a necessidade de se ampliar o conceito e a atuação da Educação no nosso tempo.

Neste cenário, observa-se uma ampliação do conceito de Educação, que não se restringe mais aos processos de ensinoaprendizagem no interior de unidades escolares formais, transpondo os muros da escola para os espaços da casa, do trabalho, do lazer, do associativismo etc. (GOHN, 2005, p. 07).

\subsection{Educação Escolar e Educação Social}

Entendendo a apropriação da cultura de uma forma mais ampla, alguns autores dividem o processo de educação em três categorias: Educação Formal, Educação não-formal e Educação Informal. Garcia, Afonso e Simson entendem por Educação Formal a educação feita nas escolas e por Educação não-formal e informal os processos educativos que ocorrem em outros espaços e instituições. A definição de Afonso (1989) resume os conceitos utilizados por estes autores:

\footnotetext{
Por educação formal, entende-se o tipo de educação organizada com uma determinada seqüência e proporcionada pelas escolas enquanto que a designação educação informal abrange todas as possibilidades educativas no decurso da vida do indivíduo, constituindo um processo permanente e não organizado. Por último, a educação não-formal, embora obedeça também a uma estrutura e a uma organização (distintas, porém, das escolas) e possa levar a uma certificação (mesmo que não seja essa a finalidade), diverge ainda da educação formal no que respeita à não fixação de tempos e locais e à flexibilidade na adaptação dos conteúdos de aprendizagem a cada grupo concreto. (AFONSO, 1989 op.cit. SIMSON, PARK, FERNANDES, 2001, p. 09).
}

Osmar Fávero (2007), em resenha elaborada sobre o livro Educação não-formal: contextos, percursos e sujeitos, dos autores acima citados, lembra que em 1970, atendendo a solicitação da UNESCO, algumas universidades americanas realizaram

centenas de pesquisas em todo o mundo para descobrir as formas mais interessantes e mais produtivas de educação não-formal ou extra-escolar. No caso dos países pobres, esse interesse estava 
intimamente ligado às preocupações internacionais com a eliminação da pobreza, em parte justificadas por razões humanitárias, mas na verdade motivadas por razões de política e segurança. (FÁVERO, 2007).

Apesar de contextualizar os estudos sobre educação não-formal, resgatando as origens dessa temática no Brasil e no mundo, na mesma resenha, Fávero informa que

Desde esses primeiros tempos, não se consegue conceituar adequadamente educação não-formal, nem se consegue categorizar convenientemente suas diversas expressões em uma tipologia. Com freqüência, está referida ao escolar, considerado, nem sempre propriamente, como formal; e com freqüência maior ainda recobre experiências as mais diversas, às vezes entendidas como educação social, que têm entre si o traço comum de serem realizadas fora do espaço e do tempo escolares. (idem).

O autor apresenta problemas com relação à utilização do termo educação não-formal, levantando três pontos de questionamento: I- não se consegue conceituar adequadamente o termo: ele nasce da negação da educação formal, outro termo não definido com precisão. II - dificuldade em conceituar educação escolar como educação formal: o termo educação formal tem sido utilizado para expressar a educação escolar, dada a sua organização curricular, que lhe confere certa forma e intencionalidade, porém, nas práticas elencadas como educação não-formal é possível também observar uma organização. Ainda que diferente das grades curriculares, as práticas educativas que ocorrem fora da escola também possuem intencionalidade e, portanto, se organizam de maneira específica. Nomeá-las como práticas não-formais poderia minimizar seus objetivos e atuações; III - não se consegue categorizar convenientemente suas diversas expressões em uma tipologia: o termo têm sido utilizado para expressar iniciativas educativas de diversas naturezas (educação indígena, educação de jovens e adultos, educação hospitalar, educação em regime de privação de liberdade etc), colocando-as simplesmente em oposição à escola, todavia, essas práticas possuem suas características específicas e precisam ser categorizadas e analisadas de forma particular.

Assim, parece pertinente considerar a afirmação de Gadotti (2000) de que

o traço mais original da educação desse século é o deslocamento de enfoque do individual para o social, para o político e o ideológico. A pedagogia institucional é um exemplo disso. A educação, no século XX, tornou-se permanente e social. (GADOTTI, 2000).

Outras instituições têm se ocupado da educação no século XX. Seja na escola ou em qualquer instituição social, essas práticas se consolidam como fazeres educativos imbuídos de 
intenção, afinal, como apontava Paulo Freire "a educação é ideológica" (FREIRE, 1996, p. 125). Assim, entendendo a educação escolar como um processo distinto da educação que se faz fora dela e sem minimizar a intencionalidade que existe nas duas abordagens, considero os estudos atuais para conceituar as práticas que Gadotti chama de permanente e social.

Em 2006, foi realizado o I Congresso Internacional de Pedagogia Social na Faculdade de Educação da Universidade de São Paulo (FEUSP), sob a coordenação do Prof. Dr. Roberto da Silva. $\mathrm{Na}$ ocasião, Caliman (2006) apresentou algumas definições sobre o que chama de Pedagogia Escolar e Pedagogia Social.

\begin{abstract}
A primeira tem uma história e é amplamente desenvolvida pela didática, ciência ensinada nas universidades. A segunda, a Pedagogia Social, se desenvolve dentro de instituições não formais de educação. É uma disciplina mais recente que a anterior. Nasce e se desenvolve no século XIX como respostas às exigências da educação de crianças e adolescentes (mas também de adultos) que vivem em condições de marginalidade, de pobreza, de dificuldades na área social. Em geral, essas pessoas não freqüentam ou não puderam freqüentar as instituições formais de educação. Mas não só: o objetivo da Pedagogia Social é o de agir sobre a prevenção e a recuperação das deficiências de socialização, e de modo especial lá onde as pessoas são vítimas da insatisfação das necessidades fundamentais. (CALIMAN, 2006).
\end{abstract}

Roberto da Silva, João Clemente de Souza Neto e Rogério Moura, em texto introdutório ao livro Pedagogia Social (2009, no prelo), tecem considerações mais precisas desta área, levando em consideração a legislação brasileira.

Os autores argumentam que a Pedagogia Social, no Brasil, tem seu aporte no princípio da amplitude da educação, inscrito no Artigo 205 da Constituição Federal de 1988:

A educação, direito de todos e dever do Estado e da família, será promovida e incentivada com a colaboração da sociedade, visando ao pleno desenvolvimento da pessoa, seu preparo para o exercício da cidadania e sua qualificação para o trabalho. (BRASIL, 1988).

A Lei de Diretrizes e Bases da Educação Nacional (LDB, Lei $n^{0}$ 9.394/96), apesar de normatizar a Educação Escolar no país, reconhece também que

A Educação abrange os processos formativos que se desenvolvem na convivência familiar, na convivência humana, no trabalho, nas instituições de ensino e pesquisa, nos movimentos sociais e organizações da sociedade civil e nas manifestações culturais (Art.1o, Lei no 9.394/96).

É importante, por isso, observar que tanto a Constituição Federal quanto a LDB, ainda que somente nos dois artigos acima reproduzidos, apresentam uma concepção ampla de Educação que 
satisfaz plenamente àqueles que entendem a Educação como um processo que acontece de forma permanente em todas as fases da vida e em todos os espaços, sejam eles públicos ou privados, formais ou não.

É então com base nos próprios marcos jurídicos que regulam a educação no Brasil que entendemos estar plenamente configurada uma Educação Escolar que tem seu aporte metodológico na Pedagogia Escolar e o aporte teórico das Ciências da Educação e outra dimensão da educação referida na Constituição e na LDB, mas sobre a qual esta última se omite, entendemos ser mais adequadamente nomeada como Educação Social.

A Educação Social recebe aporte metodológico do que os teóricos como Natorp, Nohl, Mollenhauer e Thiersch (OTTO, 2006) chamam de Pedagogia Social. Essa linha da Pedagogia tem seu início com movimentos europeus na década de 50, quando foram realizados encontros para discutir "os problemas da instrução de crianças e adolescentes inadaptados." (apud. SILVA, SOUZA NETO, MOURA, 2009, no prelo).

\begin{abstract}
Hoje, a Alemanha é reconhecida como a pátria-mãe da Pedagogia Social, que assume diferentes configurações em outros países europeus, como Áustria, Espanha, Finlândia, França, Luxemburgo, Grécia, Portugal, Noruega, Russia, Suécia, Suíça e Ucrânia. A América do Sul, a maior referência para a Pedagogia Social é o Uruguai, onde está sediada a Asociación Mundial de Educadores Sociales (AIEJI). (apud. SILVA, SOUZA NETO, MOURA, 2009, no prelo)
\end{abstract}

Nesta pesquisa busco verificar a hipótese do telecentro comunitário como um espaço de educação que está fora da escola ${ }^{53}$, e que produz diversos processos formativos. $\mathrm{O}$ intuito deste estudo não é especificar os caminhos pelos quais os indivíduos produzem ou adquirem conhecimentos no telecentro, mas verificar se existe aprendizagem neste espaço e de que tipo.

Reconheço que os conteúdos abordados nas escolas e a metodologia com a qual se trabalha nela são diferentes das que se desenvolve no espaço do telecentro. Contudo, não pretendo, com este estudo, desqualificar o papel desta instituição. Pelo contrário, reconheço sua grande importância no desenvolvimento humano e pondero, assim como Garcia (2004), que a educação que se faz fora da escola não anula a que se faz nela.

53 Os CEUs (Centros de Educação Unificado) em São Paulo - SP, possuem uma estrutura de telecentro comunitário montada para uso da comunidade escolar e externa. No CEU existe um espaço chamado TeleCEU que funciona como uma sala de informática e o telecentro que é aberto para uso livre dos interessados. Porém, apesar de estar fisicamente dentro de um espaço escolar, os telecentros dos CEUs fazem parte de uma estrutura diferenciada. Resultado da concepção de uma cidade educadora, este equipamento é tido como um equipamento social e educacional, mas não necessariamente escolar. 
A educação não-formal não tem como objetivo específico completar o que a escola deixa de fazer por motivos diversos, ou que realiza precária ou insatisfatoriamente, embora isso acabe acontecendo indiretamente. Tão pouco se opõe a ela, apenas caracterizando-se por uma maneira diferenciada de trabalhar com a educação, entendendo-a como num sentido muito mais amplo e podendo coexistir com a escola porque esta cumpre em outro papel na sociedade, responsabilizando-se por garantir a transmissão dos conteúdos socialmente acumulados, sistematizando-os. (GARCIA, 2004, p. 151)

Diferente, porém, de Garcia, prefiro classificar o telecentro como um espaço de Educação Social e não de educação não-formal, pois pretendo estudá-lo como um lugar que produz processos específicos de educação e que possui uma intenção e uma forma. O telecentro amplia a perspectiva de se fazer educação em um espaço diferente do espaço escolar. Não possui um currículo definido, mas se constitui no contexto das necessidades de uma comunidade e possui outras características que foram verificadas no estudo de caso.

\subsection{Telecentro comunitário como espaço de Educação Social}

Segundo Graciani (2006), a Educação Social tem seu início na reflexão de que todos são sujeitos capazes de aprender o mundo de diversas formas. Sob a perspectiva freireana, a autora afirma que essa premissa é verdadeira até aos mais pobres e excluídos da sociedade.

Foi a pedagogia freireana, que possibilitou esta reflexão e ação junto aos mais pobres e excluídos da sociedade. Foi esta relação social educativa que permitiu aos pobres tornarem-se sujeitos políticos, pois para Paulo Freire, toda educação é um ato político. Os excluídos contribuíram com sua pedagogia própria, suas crenças, valores e principalmente histórias de migração, de subsistência e sobrevivência em territórios áridos, propiciou que produzissem, não discursos abstratos e sem consistência empírica concreta, mas um discurso vivo, plástico, estético e poético baseado na vida. (GRACIANI, 2006).

No geral, a Educação Social no Brasil tem sido característica de uma educação voltada às camadas menos privilegiadas da população, porém essa relação não é necessariamente verdadeira se considerarmos que 
É no seio de todos os espaços que elabora, crio e recrio, que nascem as palavras e as ações que dão sentido ao ato que executamos diante da comunidade de educadores que nos cercam, em todos os lugares onde ocupamos qualquer território: escola, família, rua, igreja, comunidade. São momentos perenes onde o diálogo rompe o silêncio dando espaço para a conversa, circulando 0 ato de aprender e de ensinar simultaneamente. ${ }^{54}$ (GRACIANI, 2006).

É possível aprender em diversos espaços e em todas as relações que estabelecemos. Assim, não parto do pressuposto de que existe Educação Social no telecentro por ser um local que atende pessoas desfavorecidas socialmente, mas pelo potencial de aprendizagem possibilitado pelo acesso aos meios tecnológicos.

Para esta análise, realizou-se um estudo de caso em um telecentro comunitário da cidade de São Paulo. Já nos primeiros levantamentos, foi possível verificar as características de Educação Social apontadas por Silva (2006), o que reforça a classificação deste tipo de programa na área:

I - "caracteriza-se por não ter a preocupação de desenvolver um currículo predefinido, um currículo que se faz principalmente baseado em desejos, necessidades e interesses das pessoas" (SILVA, 2006).

O telecentro é um espaço público que permite acesso livre aos interessados. Não existe um currículo obrigatório e pré-estabelecido, embora se desenvolvam nele alguns cursos e oficinas, esse tipo de trabalho não tem uma obrigatoriedade nem um currículo definido. Isso, porém não significa que o espaço do telecentro não possua uma forma ou uma intencionalidade. Como um programa de inclusão digital, ele carrega uma gama de interesses e objetivos que precisam ser estudados, pois considera a realidade da comunidade na qual está inserido, daí a escolha por não classificá-lo como educação não-formal.

II - "o objetivo central é enriquecer a biografia dos indivíduos, ampliando a gama de vivências formativas de crianças, jovens, adultos e idosos". (Idem)

Como espaço aberto aos interessados, o telecentro recebe diferentes pessoas, com interesses

54 Maria Stela dos Santos Graciani se referindo ao trabalho que coordena na PUC-SP há 25 anos -Núcleo de Trabalhos Comunitários - que favorecem a construção do que hoje entendemos por Pedagogia Social, principalmente por sua convivência com Paulo Freire. 
diversos. Não existem restrições para utilização do espaço - há somente um controle maior com o cadastro de pessoas menores de $18 \operatorname{anos}^{55}$. Dos entrevistados na pesquisa de campo, 20\% são crianças, $49,57 \%$ adolescentes, $12,17 \%$ jovens e $18,26 \%$ adultos $^{56}$. Apesar de a maioria estar na faixa de 9 a 17 anos (crianças e adolescentes), é possível notar que o espaço é procurado por pessoas de diversas faixas de idade e para diferentes fins. Diego Amoroso (21 anos), monitor do telecentro desde a sua implantação, atesta essa diversidade de interesses na sua fala.

O que eles mais acessam é o Orkut. Tem muito jovem, de uns 13 anos, acessando aqui. Ai vem as crianças com os jogos. Quando a gente abriu aqui era muito jogo, tanto que era toda hora travando o computador porque os jogos eram muito pesados. Em terceiro, vem as pessoas pra algum tipo de serviço público... pra $C P F$, fazer cadastro de CPF, ou então o neto veio ver alguma coisa pra vó da aposentadoria... alguma coisa de cadastro... (Diego Amoroso - monitor do telecentro - em 24/07/2008).

Essa multiplicidade de interesses que o telecentro atende permite-nos constatar que o espaço foi estruturado com objetivo de possibilitar acesso da comunidade aos meios digitais e, portanto caracteriza-se como um espaço que "enriquece a biografia dos indivíduos, ampliando a gama de vivências formativas", já que os usuários teriam maior dificuldade de acesso aos recursos disponibilizados no local caso ele não existisse.

III - "a não obrigatoriedade de freqüência e a ocorrência de ações e experiências em espaços e tempos mais flexíveis, não restritos aos fixados por órgãos reguladores”. (SILVA, 2006)

Os usuários do telecentro freqüentam o local não por uma obrigatoriedade como se tem no espaço escolar, mas motivados por interesses pessoais. Não é intuito principal do telecentro oferecer certificados e diplomas, mas possibilitar o contato dos usuários com os recursos digitais de forma mais flexível e não regulamentada. No telecentro estudado, a maioria das pessoas cadastradas fazem uso do horário de acesso livre e não estão matriculadas em nenhum curso específico.

IV - "são iniciativas patrocinadas por diferentes segmentos da sociedade - de forma autônoma, mista ou em parcerias. São movimentos sociais, instituições, o Estado e seus organismos públicos e, mais recentemente, organizações não-governamentais e sociedade civil”.

55 Podem ser cadastrada, no telecentro estudado, qualquer pessoa a partir dos 5 anos de idade, com apresentação de um documento (RG) e comprovante de residência. No caso das pessoas menores de 18 anos, é necessária a apresentação de uma autorização assinada pelo responsável.

56 Ver mais detalhes do perfil dos entrevistados no item "Definição da amostra e instrumentos da coleta de dados". 
O telecentro, como abordei no Capítulo 2, possui esta característica, pois se trata de uma iniciativa de diferentes setores da sociedade. No estudo de caso, o telecentro investigado está instalado em uma organização não-governamental, principal objeto de estudo da Pedagogia Social atualmente.

As quatro características que configuram uma iniciativa como um trabalho de Educação Social apontadas por Silva foram verificadas no início das pesquisas no telecentro comunitário, o que reforçou o interesse pelo tema e pela continuidade da investigação. A essas características, posso acrescentar um aspecto importante abordado por Caliman (2006).

\footnotetext{
Uma dimensão privilegiada da Pedagogia Social é aquela dos espaços de transformação da educação não intencional, ou não declaradamente intencional, em educação intencional; de espaços deseducativos ou potencialmente educativos em espaços declaradamente educativos através de uma intervenção direta no ambiente. (CALIMAN, 2006).
}

O telecentro em sua origem e natureza não se constitui em um espaço intencionalmente educativo. Foi criado principalmente com objetivo de diminuir a desigualdade entre os excluídos e incluídos digitais e não com o intuito de ser um espaço de Educação - é a análise que se pretende fazer deste equipamento é que poderá transformá-lo em lugar educativo e, por isso pertinente aos estudos da Pedagogia Social. 


\title{
5. Tecno_Pombas: um estudo de caso
}

\begin{abstract}
Para efetivar uma pedagogia social competente e consequiente historicamente, é imprescindível: de um lado, buscar conhecer a sabedoria popular, expressa em seus códigos, dramaturgia, religiosidade, produtos culturais e senso comum, base fundamental que deve servir de plataforma para ele (indivíduo, grupo, classe popular) e os intelectuais orgânicos possam chegar à hegemonia da sociedade civil no processo concomitante de sua libertação social, econômica e política; de outro, entender que o povo não se apresenta como uma entidade única. (GRACIANI, 2006).
\end{abstract}

Por considerar que as iniciativas de Educação Social são específicas de um espaço, tempo e de uma comunidade, a escolha pela metodologia do estudo de caso, pareceu-me pertinente uma vez que, reconheço a existência de aspectos que podem ser generalizados a outros equipamentos semelhantes, mas verifico algumas especificidades também.

Para a pesquisa, foi escolhido, como objeto de estudo, um telecentro comunitário localizado no distrito de Cidade Tiradentes, Zona Leste de São Paulo - SP. Foi nesta região que a Prefeitura de São Paulo implantou o primeiro ponto do Programa Telecentro, em 2001.

A principal fonte de dados foram os próprios usuários do telecentro, por meio de questionários e pequenas entrevistas realizados no período de abril de 2007 a maio de 2008. A análise também teve como fontes, entrevistas com os monitores do telecentro e o relatório de atividades do Nomads.usp (Núcleo de Estudos de Habitares Interativos) do Departamento de Arquitetura e Urbanismo da Universidade de São Paulo - São Carlos (TRAMONTANO, PRATSCHKE, BENEVENTE et. al., 2007), que também desenvolveu suas pesquisas no local, no mesmo período.

\subsection{Caracterização da comunidade}

Cidade Tiradentes está situada no extremo leste da capital paulistana, fica aproximadamente a 35 quilômetros do marco zero da cidade, a Praça da Sé. Segundo informações do Observatório de São Paulo ${ }^{57}$, é um dos distritos mais populosos da cidade. Em 2007, a população total da região era de 257.029 habitantes (SEADE, 2007).

57 Em maio de 2007, movimentos sociais se reuniram para desenvolver um projeto de participação dos cidadãos nas decisões públicas da cidade de São Paulo, buscando melhorias das condições de vida dos cidadãos na cidade. O movimento que ganhou o nome de "Nossa São Paulo: outra cidade" desenvolveu um portal na Internet que permite a pesquisa de diversos indicadores sociais por subprefeitura. Neste Observatório é possível verificar mais dados sobre a região de Cidade Tiradentes. <http://www.nossasaopaulo.org.br/observatorio/>. 
A população de Cidade Tiradentes é composta basicamente de migrantes, principalmente nordestinos atraídos pelo sonho da casa própria e a fuga do aluguel. É o distrito de São Paulo com maior número de homens negros, juntamente com Guaianazes, e o segundo com maior número de mulheres negras (IBGE, 2000, apud. HIRAO, 2003).

Como parte da política habitacional de São Paulo nas décadas de 60 e 70, cujo principal objetivo era a erradicação das favelas, foram construídos na cidade grandes conjuntos habitacionais, distantes dos centros urbanos e com baixo custo. Com esta ação, esperava-se atender uma população economicamente desprivilegiada.

A região da Fazenda Etelvina (atual Cidade Tiradentes) se mostrou um bom local para a implantação da política habitacional, uma vez que oferecia ao Estado terrenos de baixo custo. Era uma região de latifúndios improdutivos, cujos terrenos eram muito baratos. Os primeiros conjuntos foram construídos em 1983 e inaugurados em 14 de julho de 1984.

Atualmente, devido ao grande aumento da população na região, o lugar é bem carente de equipamentos públicos sociais e culturais, mas concentra o maior complexo de conjuntos habitacionais da América Latina. Segundo dados da subprefeitura de Cidade Tiradentes, o distrito possui

\begin{abstract}
mais de 40 mil unidades habitacionais a maioria delas, construídas na década de 1980 pela COHAB (Companhia Metropolitana de Habitação de São Paulo), CDHU (Companhia de Desenvolvimento Habitacional e Urbano do Estado de São Paulo) e por grandes empreiteiras, que inclusive aproveitaram o último financiamento importante do BNH (Banco Nacional da Habitação), antes de seu fechamento. (SÃO PAULO, 2008).
\end{abstract}

A maior parte das famílias chegou à Cidade Tiradentes na década de 1990, quando os conjuntos habitacionais construídos começaram a ser ocupados, por meio dos programas sociais de habitação. Porém, a longa distância do centro da cidade e a pouca oferta de empregos na região são problemas cada vez mais crescentes no lugar, o que gera altos índices de vulnerabilidade para toda a comunidade, principalmente entre os jovens.

Em 2000, a Fundação SEADE (Sistema Estadual de Análise de Dados) realizou um estudo sobre a juventude na Cidade de São Paulo e, considerando índices sociais como escolaridade entre os jovens, mortalidade, empregabilidade etc, foi estabelecido o Índice de vulnerabilidade juvenil (IVJ). O distrito de Cidade Tiradentes se encontra no grupo de Vulnerabilidade 5, conforme demonstra a tabela abaixo. 


\begin{tabular}{|c|c|}
\hline IVJ & 77 \\
\hline Grupos de Vulnerabilidade & 5 \\
\hline População Total & $\begin{array}{l}190.65 \\
7\end{array}$ \\
\hline $\begin{array}{l}\text { Participação da População Jovem de } 15 \text { a } 19 \text { Anos, } \\
\text { no Total de Jovens do Município }\end{array}$ & 2,09 \\
\hline População de Jovens de 15 a 19 Anos & 20.763 \\
\hline Taxa de Anual de Crescimento Populacional & 7,72 \\
\hline $\begin{array}{l}\text { Taxa de Anual de Crescimento Populacional } \\
\text { (Escala } 0 \text { a 100) }\end{array}$ & 70 \\
\hline $\begin{array}{l}\text { Participação dos Jovens de } 15 \text { a } 19 \text { Anos no Total } \\
\text { da População dos Distritos (\%) }\end{array}$ & 10,89 \\
\hline $\begin{array}{l}\text { Participação dos Jovens de } 15 \text { a } 19 \text { Anos no Total } \\
\text { da População dos Distritos (Escala de } 0 \text { a 100) }\end{array}$ & 100 \\
\hline $\begin{array}{l}\text { Taxa de Mortalidade por Homicídio da População } \\
\text { Masculina de } 15 \text { a } 19 \text { Anos (por } 100.000 \text { Hab.) }\end{array}$ & 292,80 \\
\hline $\begin{array}{l}\text { Taxa de Mortalidade por Homicídio da População } \\
\text { Masculina de } 15 \text { a } 19 \text { Anos (Escala de } 0 \text { a 100) }\end{array}$ & 55 \\
\hline $\begin{array}{l}\text { Proporção de Mães Adolescentes de } 14 \text { a } 17 \text { Anos, } \\
\text { no Total de Nascidos Vivos (\%) }\end{array}$ & 9,74 \\
\hline $\begin{array}{l}\text { Proporção de Mães Adolescentes de } 14 \text { a } 17 \text { Anos, } \\
\text { no Total de Nascidos Vivos (Escala de } 0 \text { a 100) }\end{array}$ & 76 \\
\hline $\begin{array}{l}\text { Rendimento Nominal Médio Mensal das Pessoas } \\
\text { Responsáveis pelos Domicílios Particulares } \\
\text { Permanentes (R\$) }\end{array}$ & 598,82 \\
\hline $\begin{array}{l}\text { Proporção de Jovens de } 15 \text { a } 17 \text { anos que não } \\
\text { Freqüentam a Escola \%) }\end{array}$ & 29,07 \\
\hline Densidade Demográfica $\left(\mathrm{Hab} . / \mathrm{Km}^{2}\right)$ & 12.710 \\
\hline $\begin{array}{l}\text { Taxa de Fecundidade das Adolescentes de } 14 \text { a } 17 \\
\text { Anos (por } 1.000 \text { mulheres) }\end{array}$ & 45,59 \\
\hline $\begin{array}{l}\text { Proporção de Jovens, de } 18 \text { a } 19 \text { Anos, que não } \\
\text { concluíram o Ensino Fundamental (\%) }\end{array}$ & 48,78 \\
\hline
\end{tabular}

Ilustração 14: Indicadores do Distrito Cidade Tiradentes ${ }^{58}$.

A leitura dos dados a cima permite observar que o distrito tem fortes marcas de exclusão, já que a escala de vulnerabilidade utilizada para este índice varia de 1 a 5 , sendo o grupo 5 o mais vulnerável.

O índice de mortalidade entre os jovens na região é alto, se comparado a outros distritos da cidade de São Paulo. Cidade Tiradentes está no terceiro lugar no ranking de mortalidade masculina de 20 a 24 anos, no triênio 2000-2002, com seis mortes a cada 1000 homens, atrás apenas de Parelheiros (6,1) e M’Boi Mirim (6) (Fundação Seade, 2000).

${ }^{58}$ FONTE: Índice de Vulnerabilidade Juvenil, Fundação SEADE, 2000. 
Um apartamento da COHAB chega a custar, no máximo, 8mil reais, e suas dimensões físicas costumam girar em torno de $40 \mathrm{~m} 2$. Cidade Tiradentes possuía, em 1991, um dos mais altos índices de número de moradores por domicílio: 4,02. (IBGE 1991). Sua taxa de natalidade, em 1999, era de 22,92 por mil habitantes, comparativamente maior que a média do município, de 21,97 (SEADE 1999). Quanto à renda média do responsável pelo domicílio, em Tiradentes ela é de $\mathrm{R} \$ 598,00$ (IBGE2000) e é o distrito paulistano com menor índice de emprego local por habitante: um emprego formal para cada 398 moradores. ${ }^{59}$

O estudo realizado pela Prefeitura de São Paulo, no mesmo ano, confirma esta análise, uma vez que localiza Cidade Tiradentes entre os distritos de maior exclusão social da cidade. Seu Iex (Índice de exclusão/inclusão social) está na faixa de -1 a -0,50. Considerando que a escala varia de 1 a 1, sendo -1 o mais excluído e 1 o menos excluído, verificamos que a região é de fato uma região excluída de serviços sociais e desfavorecida economicamente (SPOSATI, 2000).

Avaliando estes dados, em 2001, a prefeitura de São Paulo iniciou seu Plano de Inclusão Digital com a organização e implantação de um telecentro no distrito de Cidade Tiradentes. A região foi escolhida exatamente por apresentar as características priorizadas pelo Plano: ser uma das "regiões da cidade com Índices de Desenvolvimento Humano mais baixos" (SÃO PAULO, 2003).

A Zona Leste de São Paulo é a região com mais telecentros da Prefeitura (conveniados ou sob administração direta). São ao todo 113 unidades ativas, sendo que sete dessas unidades estão localizadas no distrito de Cidade Tiradentes.

\subsection{Caracterização da Instituição: o Instituto Pombas Urbanas}

Em 1989, o diretor de teatro Lino Rojas ${ }^{60}$, com apoio de um projeto da Secretaria de Estado da Cultura de São Paulo, reuniu jovens do bairro de São Miguel Paulista para uma oficina de teatro. Deste trabalho, surgiu o Grupo Pombas Urbanas de teatro de rua, composto por jovens da periferia de São Paulo, com o sonho de se tornarem artistas profissionais.

59 Perfil sócio-histórico cultural do distrito de Cidade Tiradentes, realizado em parceria do Instituto Pombas Urbanas e Secretaria Estadual de Cultura no âmbito do Programa Fábricas de Cultura, janeiro/2004.

60 Lino Rojas Perez (1942-2005) era diretor de teatro. Nascido no Peru, esteve em São Paulo pela primeira vez em 1958 e estabeleceu residência definitiva na capital paulista em 1985. Aqui encontrou parceiros de idéias como Augusto Boal, Amir Haddad, Marcos Caruso e Cristina Mutarelli, que já faziam teatro popular com o grupo União e Olho Vivo. Eles acreditavam na mudança por meio da arte. Lino tornou-se diretor de teatro na Universidade de São Paulo - USP e, impressionado com o crescimento do número de meninos de rua na cidade, trabalhou em conjunto com Dom Paulo Evaristo Arns, Frei Leonardo Boff, e o sociólogo Herbert de Souza na construção de um abrigo no Brás. Nesta casa para meninos de rua, sua atividade era criar textos e fazer teatro. Dessa experiência nasceu, na década de 80, o projeto Semear Asas, iniciativa que deu origem ao grupo Pombas Urbanas, com o qual produziu diversas peças de teatro e viajou para festivais nacionais e internacionais. Em fevereiro de 2005, Lino Rojas foi assassinado, vítima da violência urbana. (Disponível em: < http://www.cultura.gov.br>, Acesso em out de 2008). 
Com intensa pesquisa e trabalho artístico, o grupo de jovens desenvolveu 11 espetáculos (adulto e infantil), de teatro de rua e palco italiano, se consolidou como grupo de teatro profissional e participou de festivais de teatro em vários estados do Brasil e também em outros países como Colômbia, Venezuela, Cuba, Peru, Uruguai e Chile.

Com o intuito de transferir toda essa experiência para outros jovens com situações de vida semelhantes às deles, o grupo ampliou sua ação e, em 2002, a Companhia Artística Pombas Urbanas se transformou no Instituto Pombas Urbanas, uma OSCIP (Organização da Sociedade Civil de Interesse Público), devidamente registrada, cujo objetivo era "desenvolver projetos de arte que funcionassem como ações de transformação social” (RUIZ, OLIVEIRA, 2008, p.43).

Após uma pesquisa na periferia de São Paulo, por um lugar onde pudessem desenvolver seus trabalhos, os atores do grupo conquistaram um espaço na Cidade Tiradentes, zona Leste da cidade, região de origem da maior parte dos integrantes do grupo. $\mathrm{O}$ terreno de mais de $1.600 \mathrm{~m}^{2}$, onde antes funcionava um supermercado, foi cedido pela Companhia Metropolitana de Habitação - SP (COHAB- SP) ao Instituto em contrato de comodato de 20 anos para que pudessem desenvolver no local um projeto cultural para a comunidade.

Desde 2004 os jovens de São Miguel Paulista passaram a ser gestores deste projeto cultural e social e têm se dedicado à estruturação do Centro Cultural Arte em Construção, com intuito de criar oportunidades de desenvolvimento artístico e humano para uma comunidade repleta de jovens e crianças.

As atividades desenvolvidas pelo Instituto têm como foco as Artes em geral (teatro, música, dança, circo), mas, no ano de 2006, a instituição começou a pensar numa parceria com o Programa Casa Brasil, como uma possibilidade para melhorar a infra-estrutura física do local.

\subsection{Caracterização do telecentro comunitário Tecno_Pombas}

Na verdade, a gente nunca pensou em ter um projeto como este aqui, mas ai vimos que era importante e que poderia ser uma forma de estruturar melhor o espaço e oferecer outras coisas pra comunidade. (Adriano Mauriz - integrante do Grupo Pombas Urbanas, em 07/10/2008).

O programa Casa Brasil é uma iniciativa do Governo Federal, por meio do Ministério da Ciência e Tecnologia (MCT), que mantém mais de 40 unidades em todo o país, dando suporte para implantação e recurso financeiro para a construção do local e manutenção do espaço por um período de dois anos. 
Como o programa previa a instalação modular de diversos equipamentos, a proposta se mostrou bastante interessante para a construção do Centro Cultural que o Instituto Pombas Urbanas vinha estruturando no local e por isso a busca pela parceria com o programa se tornou uma prioridade no ano de 2006.

O programa Casa Brasil tem por objetivo "levar inclusão digital, cidadania, cultura e lazer às comunidades de baixa renda" ${ }^{\prime}$. Na cidade de São Paulo, existem quatro telecentros que integram este programa: Instituto Arte e Sustento (Capão Redondo), Instituto Pombas Urbanas (Cidade Tiradentes), Instituto de Ação Cultural e Ecológica (Pirituba) e Prefeitura Municipal de São Paulo (M’ Boi Mirim). Cada unidade é composta por módulos, com a seguinte estrutura modular ${ }^{62}$ :

- Telecentro (destinado ao acesso à Internet, utilização e disseminação do software livre, realização de cursos de introdução à informática, oficinas e uso livre);

- Sala de Leitura (destinada ao incentivo à leitura, com acervo de obras de referência, informação, literatura em geral e literatura infanto-juvenil);

- Auditório: espaço público equipado com projetor de multimídia, telão, vídeo para realização de reuniões, palestras, peças de teatro e demais manifestações sociais e culturais da comunidade;

- Estúdio Multimídia: local para criação multimídia e realização de oficinas para produção de conteúdo web e oficina de rádio;

- Laboratório de Divulgação da Ciência ou Informática: ambiente para suporte à inovação tecnológica, ensino profissionalizante e popularização da ciência e informática, com montagem e reciclagem de computadores.

Por motivos diversos, porém, o espaço ainda não contava com todos os módulos do programa até a data da pesquisa de campo. Havia, na instituição, apenas a sala de leitura, as atividades culturais e o telecentro que disponibilizava acesso livre à população em geral.

Apesar de entender o telecentro como parte de um programa que inclui outras iniciativas e equipamentos, optei pelo estudo isolado dele, uma vez que o objetivo da pesquisa é refletir sobre as ferramentas de inclusão digital a partir deste equipamento específico. Assim, com este estudo de caso, não pretendo analisar o Programa Casa Brasil, mas o equipamento telecentro comunitário.

Embora tenha sofrido um assalto que resultou na perda de todos os computadores antes

61 Endereço Eletrônico do Programa Casa Brasil: http://www.casabrasil.gov.br 62 Idem. 
mesmo de sua inauguração, o Tecno_Pombas, nome dado ao telecentro, conseguiu dar início às suas atividades em abril de 2007 e pretende "ser um lugar de intercâmbio de idéias entre os membros da comunidade, visando a ampliação de seu horizonte sócio-cultural". (TRAMONTANO, PRATSCHKE, BENEVENTE et. al., 2007,p. 18)

O Tecno_Pombas possui 10 computadores, ligados em rede e permite que os usuários agendem horários para acesso livre de uma hora. Cada usuário pode fazer um agendamento por dia. Os computadores possuem somente softwares livres instalados, o que remete à concepção de Inclusão Digital da maioria dos programas para este fim no país.

Com apoio do grupo de estudantes do Nomads.usp, do Departamento de Arquitetura e Urbanismo da Universidade de São Paulo - São Carlos (EESC/USP), coordenados pela prof ${ }^{\mathrm{a}}$. Dr ${ }^{\mathrm{a}}$. Anja Pratschke, os espaços e mobiliários foram projetados para

\begin{abstract}
estimular trabalhos colaborativos, proporcionar diversas possibilidades de configuração espacial, ser facilmente deslocável por sua leveza, mas também robusto. Além disso, o mobiliário proposto pelo Nomads.usp também priorizava a facilidade de execução e baixo custo. (TRAMONTANO, PRATSCHKE, BENEVENTE et. al., 2007, p. 23).
\end{abstract}

Esse aspecto de flexibilidade reforça a hipótese do telecentro como um espaço de educação social, uma vez que valoriza a troca de conhecimentos e constitui um espaço em constante mutação.

Como não existem regras prontas para a estruturação de telecentros desta natureza, coube à equipe do local avaliar as necessidades e estruturar o ambiente de forma que pudessem garantir um espaço adequado tanto para o acesso livre quanto para as oficinas e cursos que seriam oferecidos.

no início, como eram só seis mesas, formava um " $U$ ", tanto porque no curso assim, ia ficar bom porque... o professor ia conseguir visualizar o aluno e se de repente ele tivesse com alguma dificuldade na hora de digitar, mexendo no programa, a gente ia conseguir ver, né? Porque no começo, assim, queriam colocar do contrário: que os alunos ficassem de frente para o professor. Só que ai a gente num ia conseguir ver o que os alunos tavam fazendo, então, se de repente ele tivesse com uma dúvida, ele teria que chamar ou então a gente teria que ficar andando... só que ai se ficasse ao contrário ia ficar uma coisa muito poluída, né? A gente tava de um lado, teria que correr pro outro lado, ir na lousa, explicar... então a gente acabou invertendo, deixando os monitores pra dentro e os alunos ficando de costas, mas eles nem sempre ficam de costas porque às vezes, quando a gente começa a conversar eles se viram... e como as cadeiras... as cadeiras são móveis, elas giram, né? Fica mais fácil também de eles virarem pro lado, pra frente, prestar atenção na aula e depois ir pro computador. (Diego Amoroso - monitor do telecentro - em 24/07/2008) 
A configuração do espaço permite diferentes arranjos, possibilitando a realização de rodas de conversa, sendo possíveis a troca e a interação entre os usuários e entre os monitores e os usuários - ponto fundamental para a aprendizagem na Educação Social, pois apesar de não utilizar a mesma nomenclatura de Gohn, reconheço como verdadeira a afirmação de que "a educação nãoformal tem sempre um caráter coletivo, passa por um processo de ação grupal, é vivida como práxis concreta de um grupo, ainda que o resultado do que se aprende seja absorvido individualmente". (GOHN, 2005, p. 104).

O telecentro funciona de terça a domingo, das 10:00h às 18:00h e, todos os dias, executa cadastro de novos usuários. A maior parte do tempo é reservada para o uso livre.

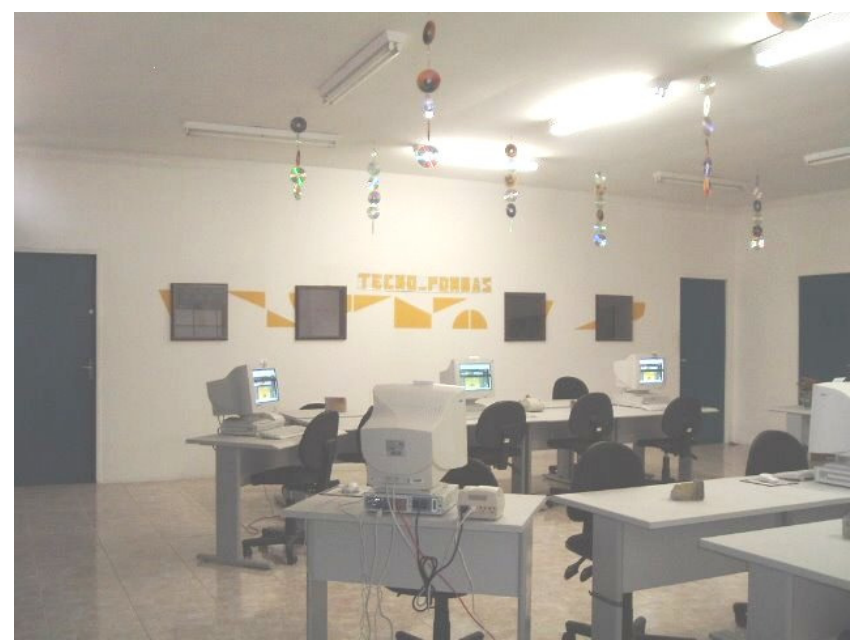

Ilustraç̃o 15: Sala do Tecno_Pombas. (Fotografia cedida pelo Instituto Pombas Urbanas, set/2007).

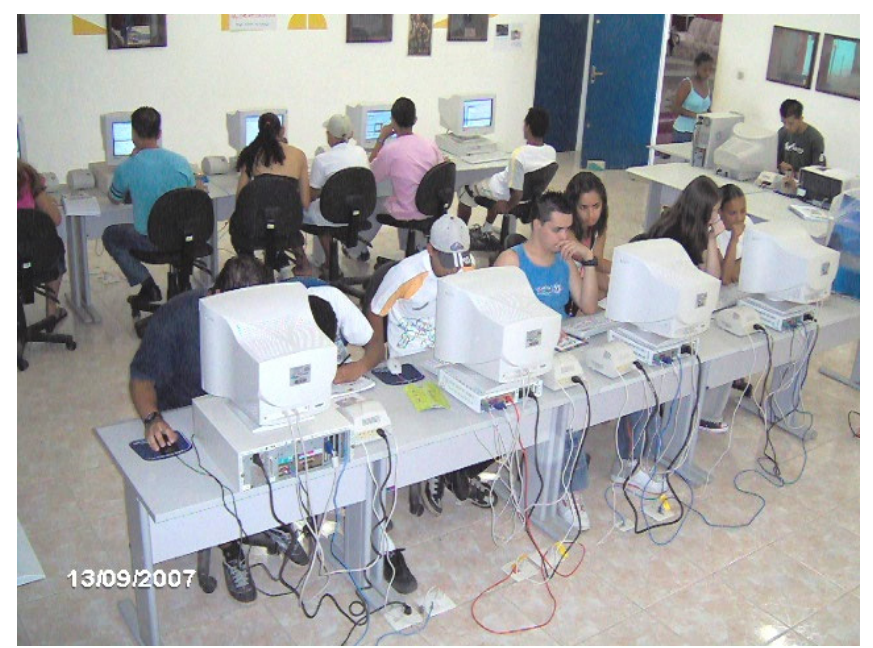

Ilustracão 16: Usuários do acesso livre - Tecno_Pombas. (Fotografia cedida pelo Instituto Pombas Urbanas, set/2007). 
Além de ser uma região significativa para a pesquisa, pois representa uma realidade em foco dos programas de Inclusão Digital, o telecentro foi escolhido porque estava em fase de implantação: os usuários haviam feito seus cadastros para acesso livre há apenas cinco ou seis meses antes da data da entrevista.

Outro motivo da escolha do telecentro para esta pesquisa foi a busca pela investigação da presença das características que definem um espaço como local de Educação Social. Além dos pontos abordados no início deste capítulo, é possível verificar, com clareza, mais três características da educação social:

I - o caráter voluntário - que é notado na forma de realização do cadastro e também na frequiência dos usuários ao local. Cada um procura o lugar por um motivo específico. A pessoa apresenta um documento e recebe uma carteirinha de associado. Cabe a cada usuário agendar seu horário de uso e não existe nenhum tipo de regra que obrigue a freqüência do usuário ao espaço. Embora não haja obrigatoriedade pela freqüência, ela costuma ser alta, como mostra as respostas da pesquisa de campo.

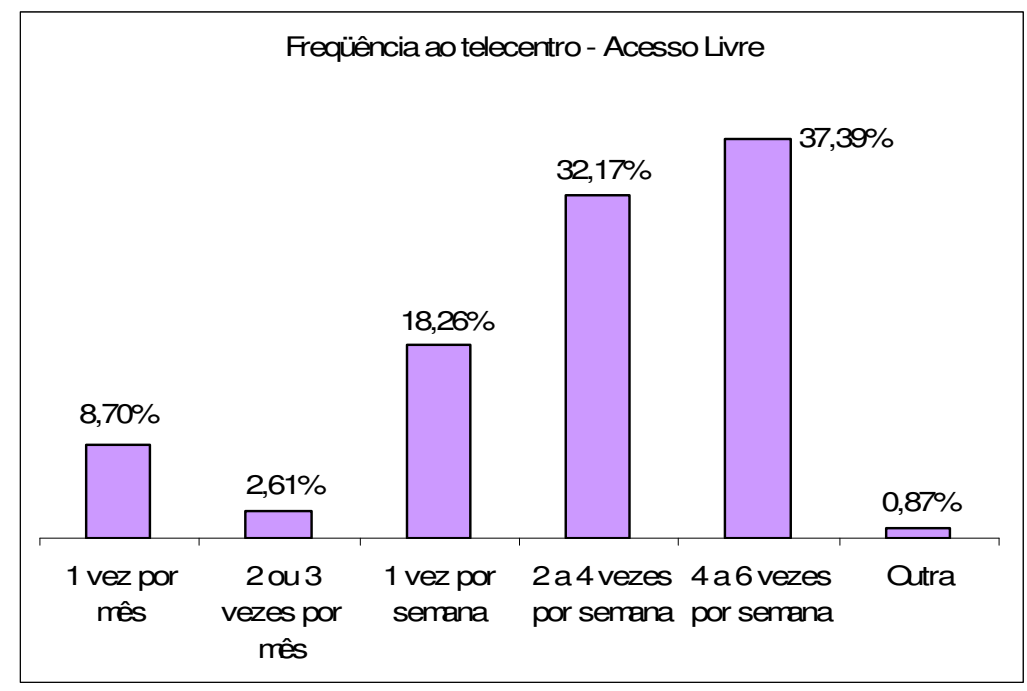

Ilustração 17: Freqüêencia ao telecentro - Acesso Livre.

A maioria dos entrevistados freqüenta o telecentro quase diariamente, pois 38,26\% declara que agenda horário para o uso livre 4 a 6 vezes por semana e 32,17\% declaram que freqüentam o local de 2 a 4 vezes por semana, como mostra a Ilustração $17 .^{63}$

63 O número de vezes que o usuário freqüenta o telecentro por semana corresponde ao número de horas que ele tem de acesso ao telecentro e seus recursos, já que cada agendamento (visita ao local) dá ao usuário o direito de 1hora para acesso livre. 
II - a oferta de elementos para a socialização - ainda que essencialmente de forma virtual, o telecentro oferece um espaço significativo para fazer amigos e interagir com pessoas diferentes. "Temos muitos adolescentes que vêm em busca de fazer contatos, aumentar seu grupo de amigos, descobrir as diferenças...”, declara Cleidionéia Benedito - coordenadora dos módulos do Programa Casa Brasil na Instituição. Os jovens usuários confirmam essa afirmativa dizendo que o acesso possibilita o encontro com outras pessoas "é como se fosse uma praça, onde a gente conhece pessoas, mas é uma praça diferente, uma praça virtual. Eu falo com um monte de gente pelo Orkut, que eu não conheço assim de verdade, de ver mesmo." (Marcelo, 25 anos - usuário do telecentro).

Muitos usuários, quando perguntados sobre a razão de freqüentar o telecentro, afirmam que fizeram amigos e conheceram pessoas no local. Eles citam, como exemplo, os monitores, os professores dos cursos de artes oferecidos no Centro Cultural e os jovens alunos dos cursos o que mostra que esta socialização além de virtual pode também ser presencial.

III - o foco no desenvolvimento social - embora não esteja no discurso da instituição, nem nos objetivos principais do telecentro, este equipamento, por si só já se constitui em um importante elemento para o desenvolvimento social, na medida em que se mostra como uma oferta de serviço e garantia do direito à comunicação à parcela da população que não teria de outra forma. Embora somente $8,70 \%$ dos entrevistados tenham declarado que só possuem o telecentro para o acesso a computadores e 12,17\% à Internet (Ilustrações 18 e 19), esses números se tornam bem interessantes quando as pessoas apontam quais espaços utilizam para acesso além do telecentro em questão. 


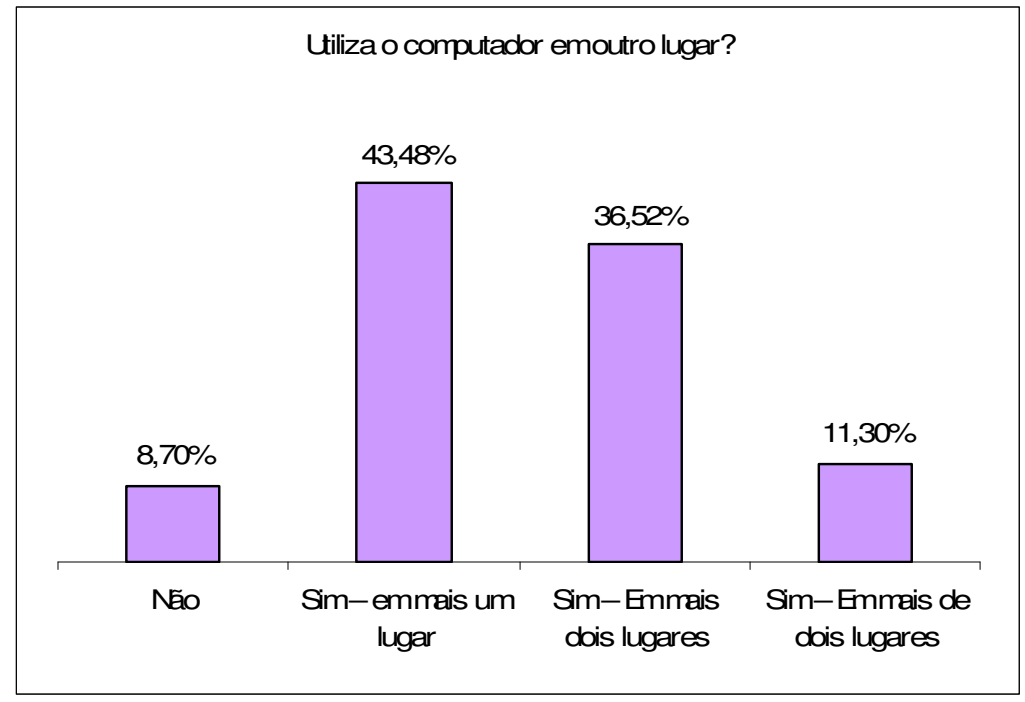

Ilustraç̃o 18: Utiliza o computador em outro lugar?

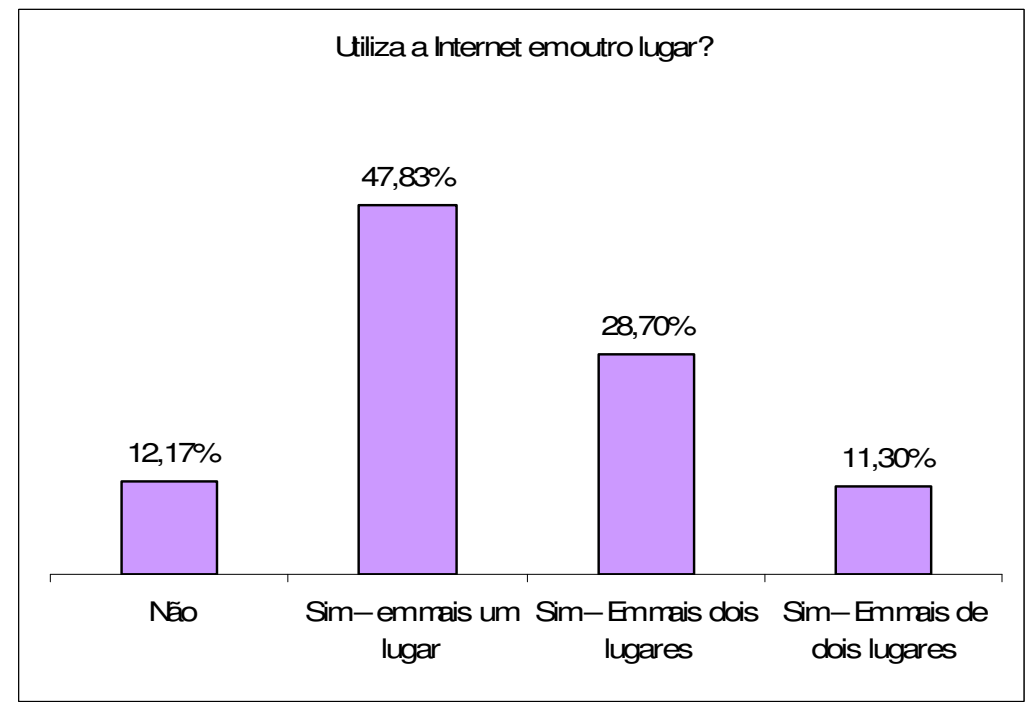

Ilustracão 19: Utiliza a Internet em outro lugar?

Somente $26,09 \%$ possuem computador em casa, ao passo que $49,57 \%$ utilizam casas comerciais de acesso (lan houses). O número de usuários que freqüentam outros telecentros também é expressivo (33,04\%), o que confirma a hipótese deste equipamento como oferta gratuita de um importante serviço a essa comunidade. ${ }^{64}$

64 A soma das respostas, neste item, ultrapassa a 100\% porque era permitido aos entrevistados dar múltiplas respostas existem pessoas que freqüentam mais de um dos espaços listados neste gráfico. A principal resposta que aparece na alternativa "Outro" é a residência de um parente ou amigo. 


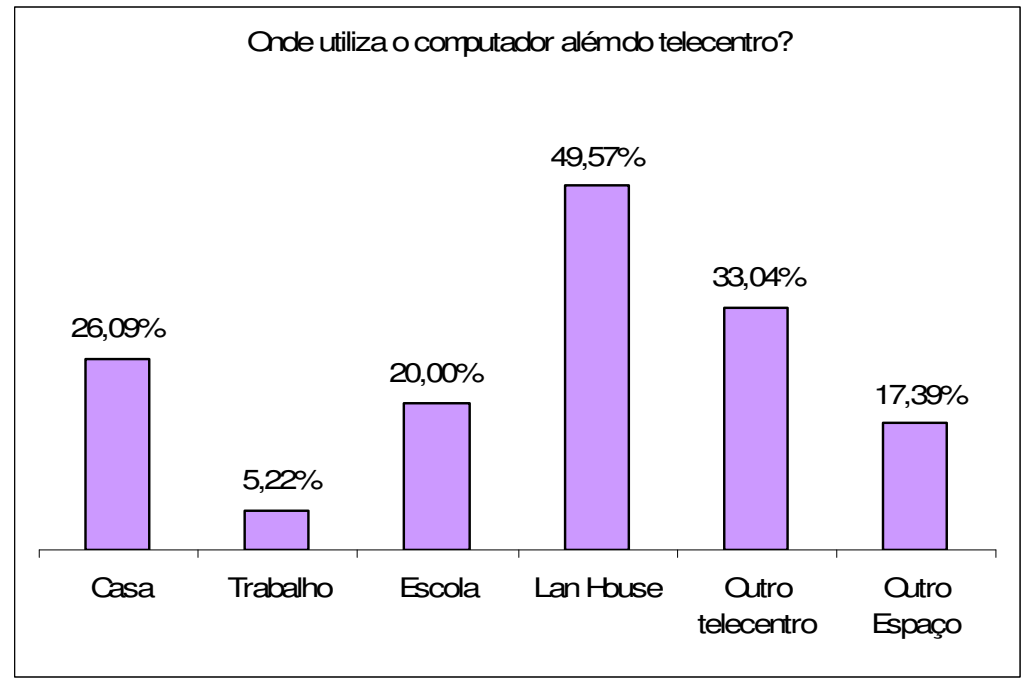

Ilustração 20: Onde utiliza o computador além do telecentro?

Quando questionados a respeito do acesso à Internet, as respostas se modificam um pouco, uma vez que nem todos que possuem computador em casa, possuem conexão para acesso à rede, dado o alto custo cobrado pelo serviço. Em muitos lugares o acesso à Rede Mundial de Computadores ainda depende de linha telefônica ou de serviços que estão além da capacidade financeira das pessoas. Os custos para acesso em banda larga são caros e não atingem a todos os pontos da cidade de São Paulo.

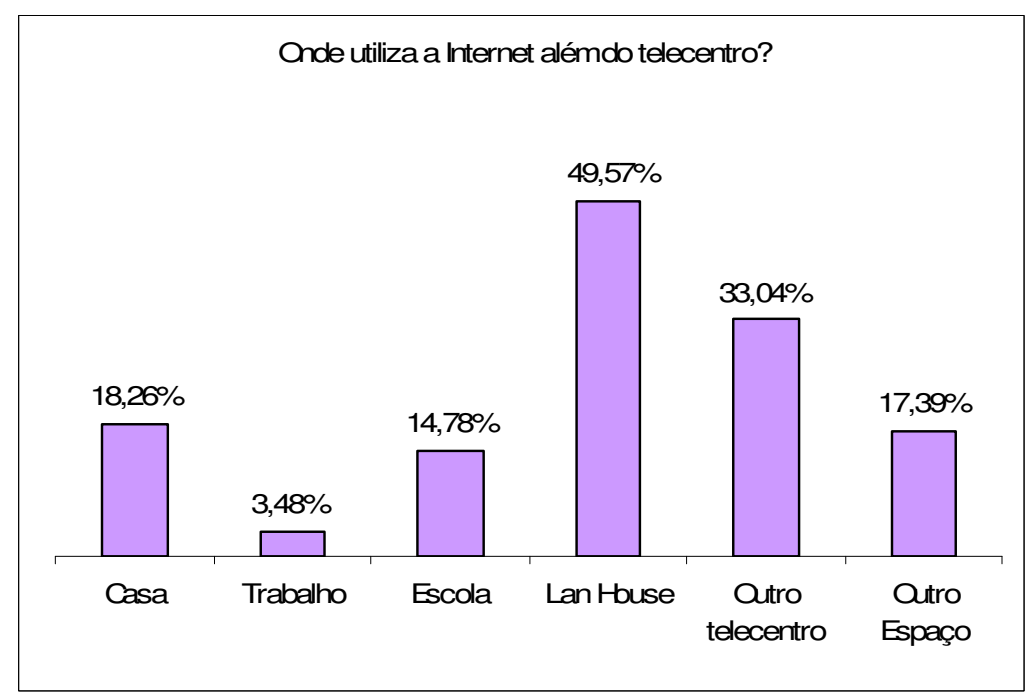

Ilustração 21: Onde utiliza a Internet além do telecentro?

5.4. Definição das fontes: levantamento bibliográfico, amostra e instrumentos para a coleta de dados 
O levantamento bibliográfico preliminar permitiu identificar cinco estudos sobre telecentros realizados nos últimos seis anos:

MACADAR e REINHARD (2002), em seu artigo publicado em Anais de congresso em Salvador, fazem uma análise crítica de duas iniciativas de telecentros brasileiros: telecentros comunitários de Porto Alegre e o Projeto Sampa.org. O estudo teve como objetivo verificar como as iniciativas brasileiras têm proporcionado acesso dos excluídos digitais às TICs. Os autores afirmam que a experiência de São Paulo está mais estruturada e atinge mais usuários que a de Porto Alegre. Eles também atentam para o fato de que o principal problema enfrentado por essas iniciativas é a sustentabilidade dos projetos.

LAIPELT et.al. (2003), também em artigo publicado, apresentam os telecentros como iniciativa de inclusão digital. As autoras caracterizam os diversos tipos de equipamentos desta natureza, destacando os telecentros comunitários. O objetivo do estudo foi o de trazer algumas reflexões sobre conteúdos que devem fazer parte da qualificação de pessoal para os telecentros e apresentar a experiência desenvolvida no Programa de Formação dos Monitores dos Telecentros Comunitários de Porto Alegre.

DELGADILLO, GÓMEZ, STOLL (2003), em estudo apoiado pelo Centro Internacional de Pesquisa para o Desenvolvimento (CIPD), Canadá ${ }^{65}$, apresentam os resultados de pesquisas desenvolvidas em telecentros comunitários na América Latina e no Caribe e afirmam que esse tipo de equipamento tem sido bastante implantado nessas regiões, pois representam uma grande oportunidade para o desenvolvimento humano. Os autores afirmam que o telecentro é um instrumento que procura diminuir a brecha digital.

SELAIMEN (2004), em pesquisa desenvolvida pela Rits, que trabalhou em parceria com a Coordenadoria Geral do Governo Eletrônico da Prefeitura Municipal de São Paulo (2002-2004), desenvolveu um levantamento social, com a proposta de conhecer o público majoritário dos telecentros de São Paulo e saber de suas expectativas, demandas e interesses prioritários a fim de elaborar produtos e serviços adequados.

65 A edição em português foi produzida pela Rede de Informações para o Terceiro Setor (Rits), com apoio da Fundação Friedrich. 
TREVISAN (2005), em sua dissertação de Mestrado na Escola de Engenharia de São Carlos (USP), analisa experiências que utilizam as TICs, em especial a Internet, com intuito de promover a inclusão digital de comunidades menos favorecidas no Brasil e no mundo. $\mathrm{O}$ autor aborda experiências em comunidades, em especial as experiências de telecentros e busca, com seu estudo, refletir sobre as relações da inclusão digital e da inclusão social.

As pesquisas acima constituíram a base referencial a partir da qual foi desenhado o estudo de caso. Para tornar operacional este estudo, foi necessário eleger um telecentro comunitário para análise das mesmas ou de categorias semelhantes tratadas nas pesquisas encontradas.

A principal fonte de dados para este estudo de caso foram os usuários cadastrados no telecentro escolhido. Como ele não limita o número de usuários a serem cadastrados para acesso livre, seria difícil definir o tamanho da amostra de maneira precisa e confiável estatisticamente, por isso fez-se necessário um recorte do público.

Um total de 571 usuários estavam cadastrados no telecentro até junho de 2007. Conseqüentemente, conhecendo o tamanho da população, o tamanho da amostra foi calculado para populações finitas $(<100.000$ elementos), com nível de confiança em 95\% e estimativa de erro $(\sigma)$ em 5\% (p<0.05). Para o total de questionários considerou-se $90 \%$ como verdadeiros-positivos. Assim, o tamanho da amostra determinado para esta pesquisa foi de 115 usuários do telecentro' segundo cálculo demonstrado no Anexo I.

Como instrumento para a coleta de dados no telecentro foi escolhido um roteiro (questionário semi-estruturado) com sete questões fechadas e uma aberta, aplicado aos 115 usuários da amostra.

As perguntas foram feitas pessoalmente pela pesquisadora ${ }^{66}$, portanto, além de se caracterizar como um questionário, o instrumento serviu de base para as entrevistas.

A primeira parte do roteiro (Anexo II), pretendia traçar o perfil dos usuários do telecentro, compreendendo sua atividade principal, faixa etária e interesses gerais pelo equipamento. As variáveis analisadas e tabuladas para compreender o perfil dos usuários tiveram como base a pesquisa feita pela Rits (Rede de Informação do Terceiro Setor) (SELAIMEN, 2004) e os dados do cadastro de usuários do telecentro estudado. Destaca-se que, não obstante a Cidade Tiradentes estar representada no estudo da Rits, o telecentro ora estudado não existia à época. Acrescentou-se ao

66 Na pesquisa de Selaimen (2004), de uma amostra previamente selecionada de 403 indivíduos obteve-se resposta para apenas 269 questionários, na mesma região do telecentro escolhido. Com intuito de evitar tantas perdas, nesta pesquisa, optou-se por entrevistas pessoais (utilizando um questionário como roteiro) com cada um dos usuários que compõem a amostra de 115 sujeitos. 
questionário itens para tratar da especificidade da população local e dos questionamentos específicos desta pesquisa.

A segunda parte teve como principal objetivo entender melhor as relações dos usuários com o telecentro (que ferramentas utilizam, que tipo de aprendizagem o telecentro proporcionou etc). As perguntas dessa parte do roteiro foram pensadas na tentativa de responder alguns questionamentos, ora problematizado nos estudos anteriores, ora identificado como novo problema de pesquisa neste estudo:

- Com os acessos livres, existe uma melhora na apropriação dos equipamentos e ferramentas por parte dos usuários?

- Existe algum tipo de aprendizagem? Como ela é produzida?

- Que relações podem ser construídas entre o espaço (telecentro) e o seu usuário?

Todas as questões do roteiro têm caráter subjetivo e se referem às percepções que os usuários fazem deste espaço e da sua relação com ele, por isso vale ressaltar que os entrevistados já faziam uso dos equipamentos há pelo menos cinco meses e por isso conseguiram responder às questões de acordo com as suas percepções com relação aos equipamentos e ferramentas utilizados.

Como as respostas são bastante subjetivas, podendo variar de acordo com as condições em que elas foram dadas, o teste de confiabilidade foi realizado a fim de minimizar as dúvidas com relação aos resultados.

Antes de aplicar os questionários aos 115 usuários da amostra, foi necessário testar o instrumento de pesquisa, verificar a necessidade de adequações das questões e a forma de apresentá-las aos entrevistados.

Essa fase inicial da coleta de dados - o teste de confiabilidade - teve como objetivos verificar a aplicabilidade do questionário ao público-alvo e verificar a correlação das respostas dadas pelos usuários em dois momentos.

Cada entrevistado foi questionado a respeito de dez aspectos ou ferramentas que podem ser encontradas neste espaço, permitindo-se como resposta quatro alternativas:

I - Nada (Não faz uso);

II - Pouco (usa, mas não muito);

III - Razoável (faz uso, mas não é freqüente);

IV- Muito (utiliza com freqüência). 
Essas perguntas pretendem verificar se existe uma melhora na utilização dessas ferramentas disponibilizadas no telecentro por parte dos usuários e quantificar essa mudança. Para tanto, só é possível contar com as respostas dadas pelos próprios entrevistados.

Nesta fase, foram entrevistados 17 usuários, selecionados de forma aleatória. O mesmo questionário foi aplicado a eles duas vezes, com intervalo de uma hora entre uma aplicação e outra. O objetivo era verificar se existia uma correlação entre as respostas dadas entre a primeira e a segunda aplicação.

Com o intuito de verificar se as medidas avaliadas pelo questionário eram confiáveis, foi realizada análise de concordância entre si para cada um dos itens da questão 7 (sete), que trata da qualificação (por parte do entrevistado) sobre suas habilidades e atividades no telecentro.

Procedeu-se com medidas repetidas para análise da confiabilidade interna. As medidas foram convergidas para escala numérica e, foi dado o coeficiente de correlação $(r)$ momento produto de Person (DAWSON; TRAPP, 1994, p. 164-167).

Em seguida, foi avaliado se as características das medidas se alteravam nos dois momentos. Para este fim, foi utilizado o teste de qui-quadrado para comparar proporções pareadas (DAWSON; TRAPP, 1994, p.102). Os dados são expressos como média da mudança percentual $\sigma$ desvio padrão da média. O nível de significância estatística adotado foi de $\mathrm{p}<0.05$.

Realizado o Cálculo do coeficiente da correlação, verificou-se que somente o item "Pesquisas Diversas" não apresentou resultados no Intervalo de confiança, portanto esta medida não será considerada na análise dos resultados desta pesquisa.

Os gráficos abaixo mostram os resultados de cada um dos itens analisados. A medida de referência (Intervalo de confiança) para a verificação desejada é de:

$0,380>\mathrm{r}<0,946$ (sendo $r$ o coeficiente de correlação) 
$\mathrm{p}<0,05$ (sendo $p$ o nível de significância estatística adotada)

\section{Reprodutibilidade das respostas}
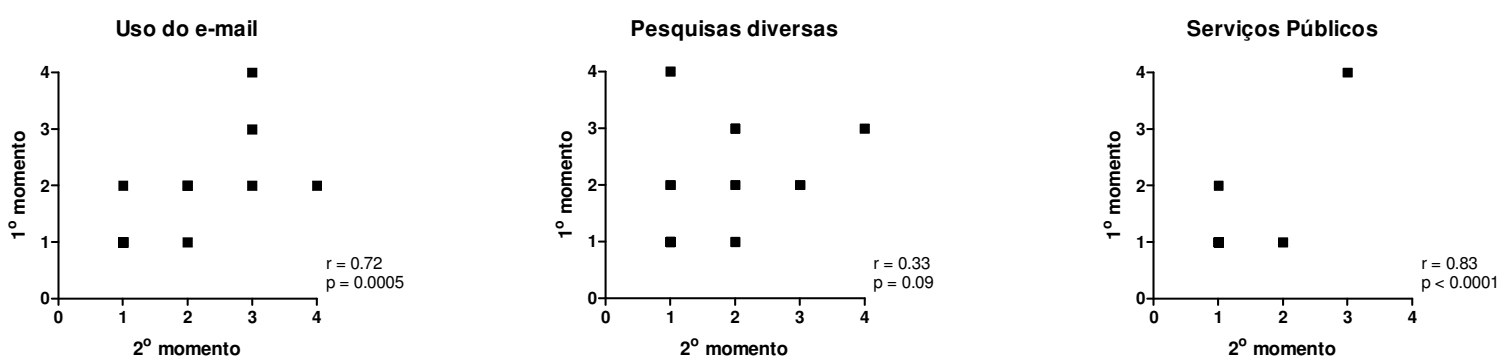

Participação em comunidades pela internet
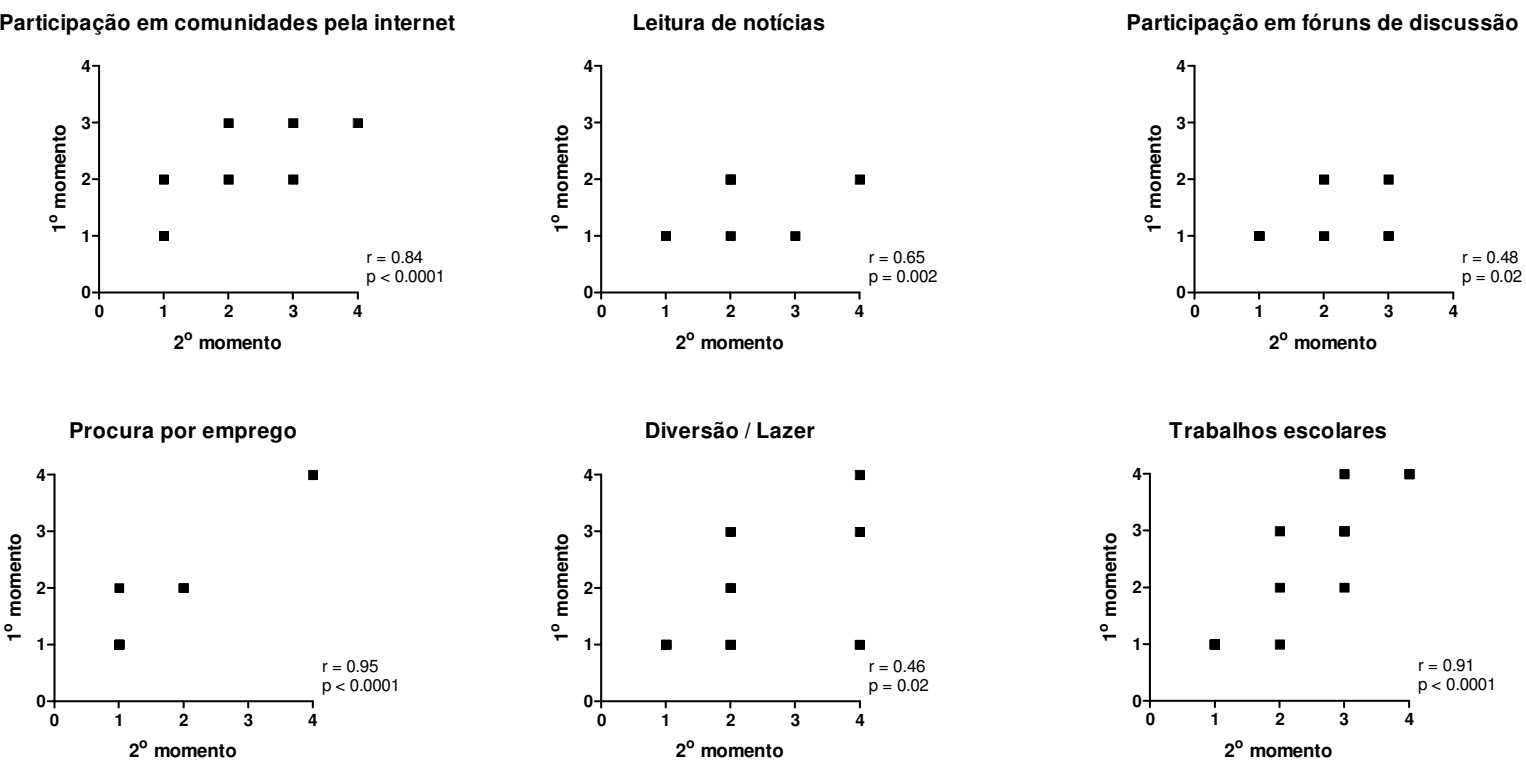

Ilustração 22 - Coeficiente de Correlação ${ }^{67}$

Obedecendo ao critério para composição da amostra, foram entrevistados os usuários cadastrados no telecentro até o mês de junho de 2007. As entrevistas foram realizadas nos meses de novembro de 2007 a março de 2008. A escolha dos sujeitos da pesquisa foi feita de forma aleatória, os usuários foram abordados quando agendavam um horário para a utilização do telecentro. Assim, o acesso ao público desejado para a composição da amostra foi facilitado, devido à dinâmica da própria instituição.

Os encontros com os usuários foram feitos antes ou depois de seu acesso livre, entre um horário e outro. Cada um dos entrevistados respondeu às oito questões da entrevista e suas respostas

\footnotetext{
${ }^{67}$ Coeficiente de Correlação. Referente à correlação das respostas dadas na fase inicial da pesquisa de campo (Teste de confiabilidade). (DAWSON; TRAPP, 1994, p.165).
} 
foram tabuladas de acordo com os interesses desta pesquisa.

Os entrevistados foram informados quanto ao procedimento e objetivos da pesquisa e a participação se deu com o consentimento dos mesmos.

Com intuito de aprofundar os dados quantitativos obtidos através dos questionários, após tabulação da parte quantitativa, procedi também entrevistas com alguns usuários e com os funcionários (monitores) do local. Os depoimentos serão apresentados no decorrer dessa dissertação quando se fizerem oportunos.

\subsubsection{Caracterização do público atendido no telecentro}

A análise do perfil dos usuários do telecentro permite verificar que este espaço cumpre seu principal objetivo de ser um equipamento de acesso às tecnologias e inclusão digital, uma vez que parte dos usuários não possui acesso a esses recursos em outro lugar (8,70\% não utilizam o computador em outro espaço e 12,70\% não acessam a Internet).

Por outro lado, o telecentro não é a única fonte de acesso para a maioria das pessoas. Como demonstrado nas ilustrações 18 a 21, muitos usuários fazem uso das tecnologias em outros locais, principalmente nas lan houses (pontos de acesso às Tecnologias Digitais de caráter comercial), onde o acesso custa, em média, $\mathrm{R} \$ 2,00$ por hora.

Quando perguntados sobre os motivos de freqüentarem as lan houses, os usuários afirmam que as ferramentas e recursos que utilizam neste local são os mesmos que utilizam no telecentro, mas fazem declarações como a de Flávio (17 anos) "É vício...(risos)". O adolescente diz que freqüienta as casas comerciais porque está acostumado, não tendo um motivo mais específico. Caroline, de 15 anos, faz uso nos dois lugares por comodidade (proximidade da casa, economia etc) "Eu vou mais no final de semana na lan house e dia de semana eu venho aqui".

Apesar das lan houses aparecerem em grande número na pesquisa como um ponto de acesso, quando perguntados sobre a motivação para freqüentar o telecentro, muitos usuários declaram que a vantagem deste espaço é a gratuidade, característica que as casas comerciais não possuem e que comprova a hipótese de que, em uma região onde o índice de desemprego da população é alto e a renda média mensal das famílias é baixa (como mostra a Ilustração 14, no item 5.1.), garantir acesso apenas com a oferta de serviços pagos não representa uma alternativa real para a inclusão digital.

A declaração de um dos entrevistados ilustra bem o que representa o telecentro como ponto de acesso às tecnologias digitais: "Eu vou na Lan House também, mas aqui é melhor porque é de 
graça, né? Com o dinheiro que eu gasto lá, dá pra comprar um monte de pão! Ai é bom porque eu economizo!" (Antonio, 21 anos).

A escola pública, por meio das salas de informática e assim como o telecentro, seria uma boa alternativa gratuita para a democratização do acesso às tecnologias para esta comunidade, porém, quando fazemos um recorte da amostra, verificamos que os usuários que se declaram estudantes não costumam utilizar os recursos de informática na escola. 86,96\% dos entrevistados são estudantes. Destes, somente $22,92 \%$ declaram fazer uso do computador na escola e 20,83\% da Internet.

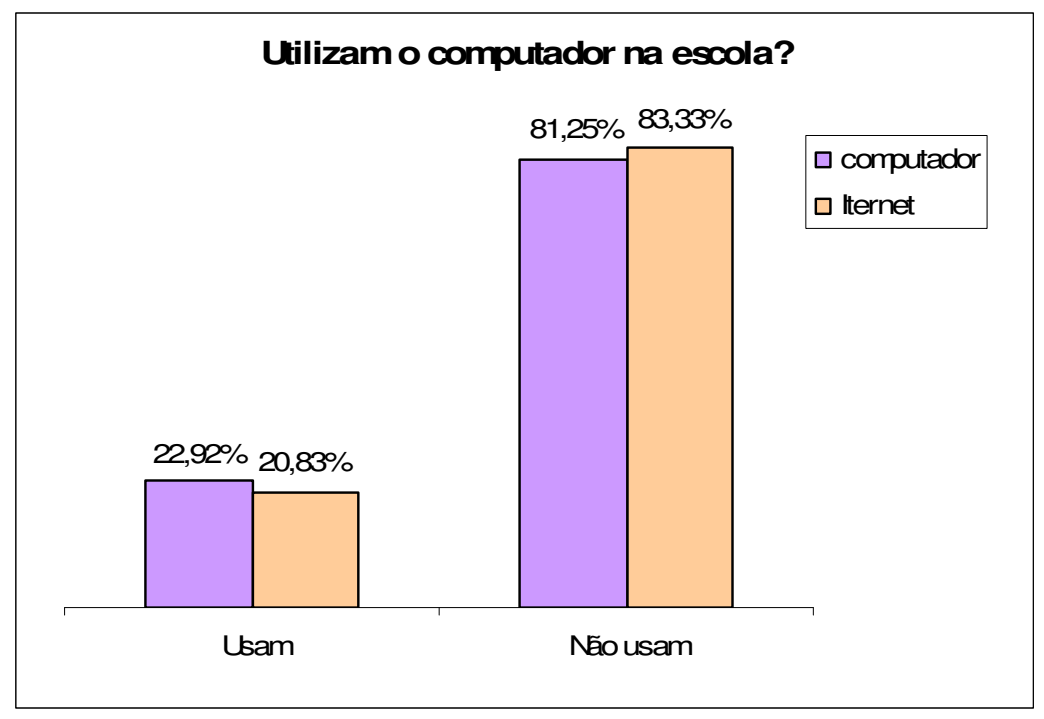

Ilustração 23 - Utiliza o computador e a Internet na escola?

Apesar da existência de programas para a estruturação de ambientes de informática tanto nas escolas estaduais como nas escolas municipais, os estudantes dizem que enfrentam alguns problemas para a utilização deles. Quase todos os alunos dizem que suas escolas possuem ou possuíam equipamentos de informática, mas a falta de manutenção dos equipamentos, a falta de motivação e conhecimentos das ferramentas disponíveis por parte dos professores, a não autorização para utilização por parte da coordenação ou direção e - o mais freqüente - o furto dos equipamentos dificultam o acesso.

O telecentro, nesta comunidade, portanto, não é a única opção de acesso das pessoas às tecnologias digitais, porém se mostra como a principal delas, quando falamos em lugares gratuitos e que por isso, não restringe sua utilização a nenhuma pessoa, ainda que ela não possa pagar pelos serviços que utilizará. 
Além da gratuidade, outra característica que reforça a função de democratização do acesso às tecnologias no telecentro é o atendimento a diferentes tipos de pessoas e interesses.

O gráfico referente à faixa etária mostra que, apesar de pessoas com idades variadas freqüentarem o telecentro, a maioria dos usuários é adolescente (12 a 17 anos), sendo que, dos 115 entrevistados, $20 \%$ são crianças, $49,57 \%$ adolescentes, $12,17 \%$ jovens e $18,26 \%$ adultos. ${ }^{6}$

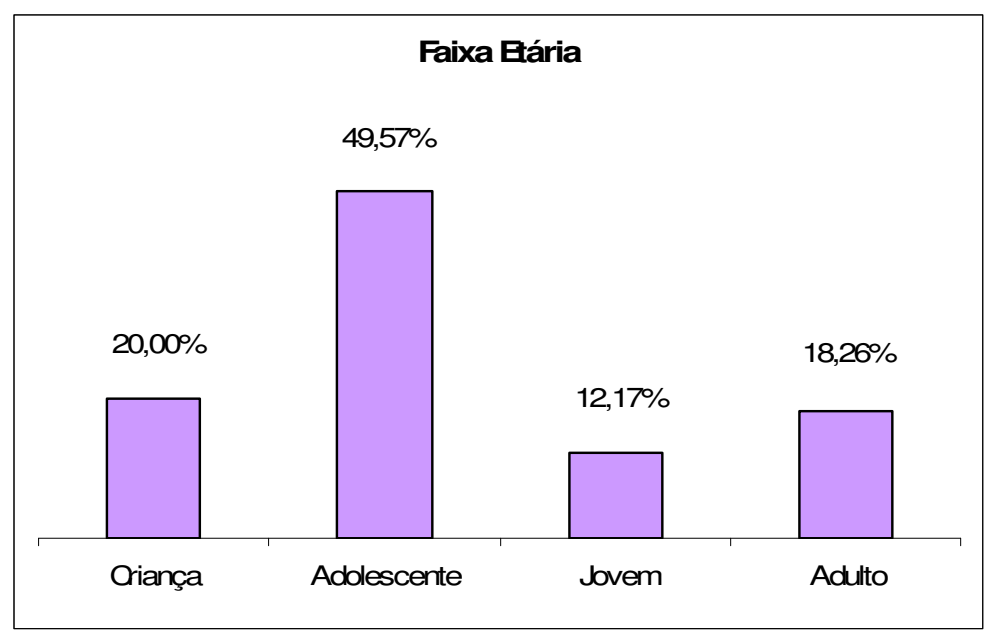

Ilustração 24 - Faixa Etária

A forte presença de crianças e adolescentes neste espaço reforça as hipóteses de que esta geração está mais familiarizada com as tecnologias, pois nasceram em uma sociedade já informacional. Para eles, o contato com as máquinas não é algo assustador, mas faz parte de uma história próxima e viva. São nativos desta Era Digital e Informacional, vêm em busca de entretenimento e lazer, que sabem que podem encontrar por meio dos recursos tecnológicos.

Quanto ao sexo, a amostra de entrevistados foi bem equilibrada, embora a maioria seja do sexo masculino $(57,39 \%)$.

68 Para a classificação em Faixas Etárias, utilizou-se o critério da Legislação brasileira, tomando como referências o Estatuto da Criança e do Adolescente (Lei No 8.069 de 13/07/1990) e o Estatuto do Idoso (Lei No 10.741 de 01/10/2003).

Considera-se, portanto:

Criança - pessoa até 12 anos de idade incompletos (Art. $2^{\circ}$, Lei $\mathrm{N}^{\circ} 8.069 / 90$ ).

Adolescente - pessoa entre 12 e 18 anos de idade (Art. $2^{\circ}$, Lei $\mathrm{N}^{\circ}$ 8.069/90).

Jovem - pessoa entre 19 e 21 anos (Art. $2^{\circ}$, Lei $\left.N^{\circ} 8.069 / 90\right)$.

Adulto - pessoa entre 22 e 59 anos.

Idoso - pessoa com idade igual ou superior a 60 anos (sessenta) anos (Art. $1^{\circ}$, Lei № 10.741/03). 


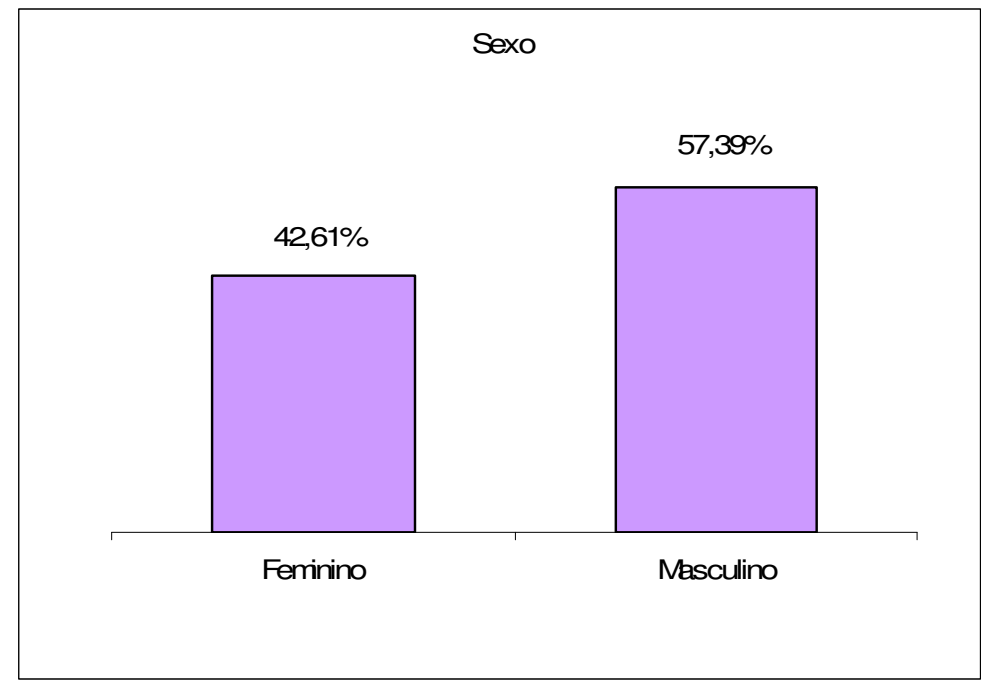

Ilustraç̃o 25 - Sexo

Quanto à ocupação, seguindo o critério do perfil da faixa etária, a maioria é estudante $(73,04 \%), 10,43 \%$ estudam e trabalham, $7,83 \%$ são trabalhadores, sendo que somente $3,48 \%$ deles possuem registro. $8,70 \%$ se declaram desempregados.

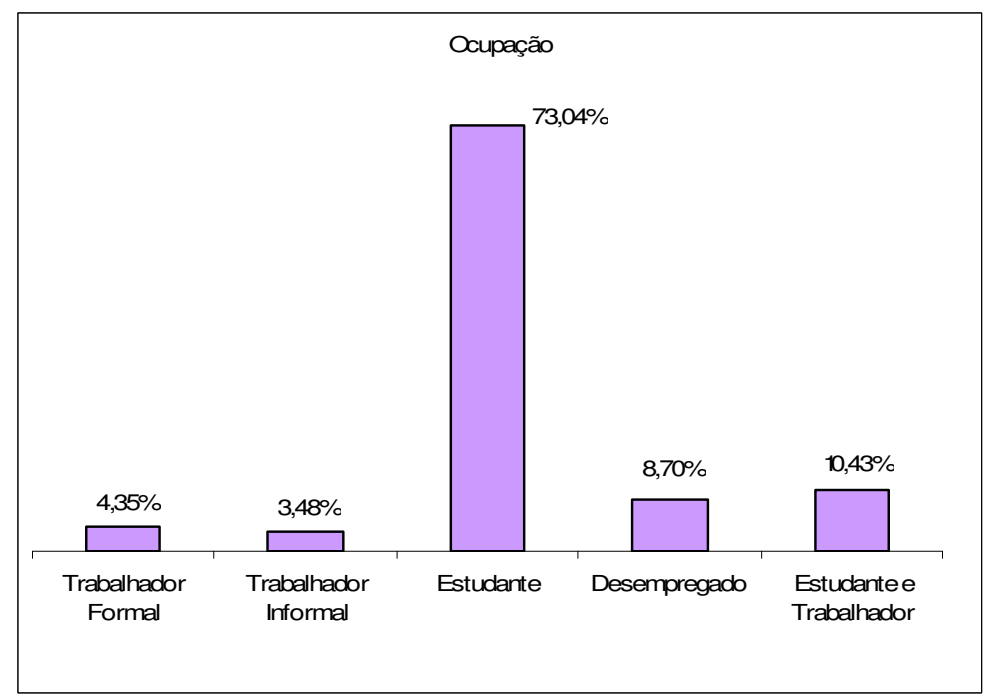

Ilustração 26 - Ocupação

A escolaridade dos usuários segue o mesmo padrão dos gráficos da faixa etária e da ocupação, já que a maioria dos entrevistados é criança e adolescente, portanto pessoas com idade escolar obrigatória. 


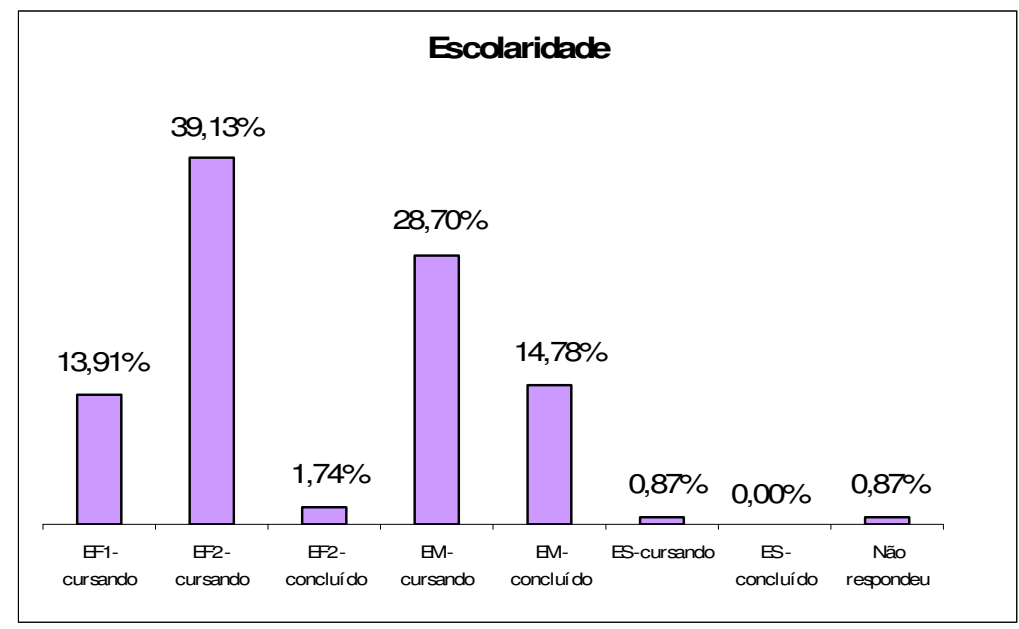

Ilustracão 27 - Escolaridade

Fazendo o recorte da amostra entre os adultos, é possível verificar que a maioria terminou a Educação Básica (Ensino Médio)- 52,38\% e boa porcentagem de adultos está estudando: 33,33\% no Ensino Médio e 4,76\% no Ensino Fundamental e 4,76\% o Ensino Superior.

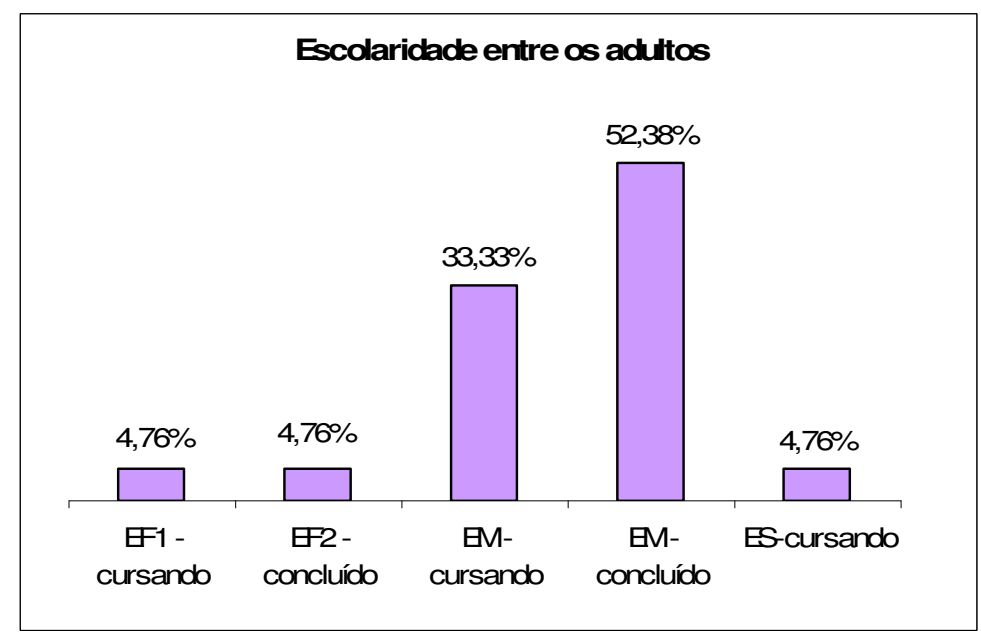

Ilustração 28 - Escolaridade entre os adultos

Os dados dos gráficos de faixa etária, ocupação e escolaridade permitem verificar a presença de diferentes tipos de usuários que freqüentam o telecentro. A coordenadora do programa na instituição resume este perfil em três categorias.

são três perfis: aquele que vem só para aumentar o grupo de amigos, aquele que vem fazer a pesquisa e aquele que vem em busca por uma vaga de emprego. (Cleidionéia Benedito coordenadora dos módulos do Casa Brasil na Instituição, em $31 / 07 / 2008)$ 
Cleidionéia ainda detalha mais estes perfis dizendo que são os adolescentes que vão em busca de relacionamentos e para fazer trabalhos e pesquisas escolares, mas ressalta que adultos, em sua maioria, vão em busca de recursos para encontrar um emprego. No telecentro, tanto um tipo de usuário como o outro tem acesso aos mesmos recursos e podem contar com o auxílio de um monitor que fica à disposição de quem o solicitar.

O monitor Diego, que passa todo o tempo monitorando o acesso livre e oferecendo cursos e oficinas de informática, verifica outras duas distinções no perfil dos usuários:

Geralmente as pessoas que vem participar (dos cursos) são as pessoas que não freqüentam o espaço - que são as que não tem conhecimento mesmo, ai elas vêm primeiro pra fazer o curso pra depois começar a usar, né? Pesquisadora: E quem já usa o horário livre? Não faz curso? Não. Os que já usam mesmo não. Curso de informática mesmo não. Só se for um desses cursos mais avançados exemplo o de edição de imagens ou HTML.(Diego Amoroso - monitor do telecentro, em 24/07/2008).

Para a composição da amostra da pesquisa, foram priorizados os usuários do acesso livre, porém, como aponta a própria declaração do monitor Diego, os usuários do telecentro atendem a dois perfis bem distintos, tomando como princípio suas motivações e origens:

I - Usuários que se cadastram para acesso livre - já chegam ao telecentro com certo conhecimento de informática. Conhecem minimamente os recursos e desejam utilizar ferramentas de seu interesse. O interesse está muito ligado à faixa etária da pessoa como citado acima. Quando existe oferta de cursos que posam ampliar seus conhecimentos em uma determinada área, mais específica e mais complexa, eles se cadastram nos cursos do telecentro, mas na maioria das vezes vão apenas para o uso livre.

II - Usuários que se cadastram para fazer cursos ou oficinas - são pessoas que chegam ao telecentro atraídos pela divulgação dos cursos e oficinas. Em geral, este público é novo e se matricula em cursos de informática básica, editor de texto, cursos mais instrumentais, pois acreditam que precisam se "capacitar", se instruir para poder utilizar as ferramentas no acesso livre.

A proporção de cada um dos perfis pode ser vista no gráfico abaixo, onde $73,04 \%$ dos entrevistados na pesquisa de campo dizem não ter feito nenhum curso e somente $4,35 \%$ declaram ter feito curso neste telecentro. 


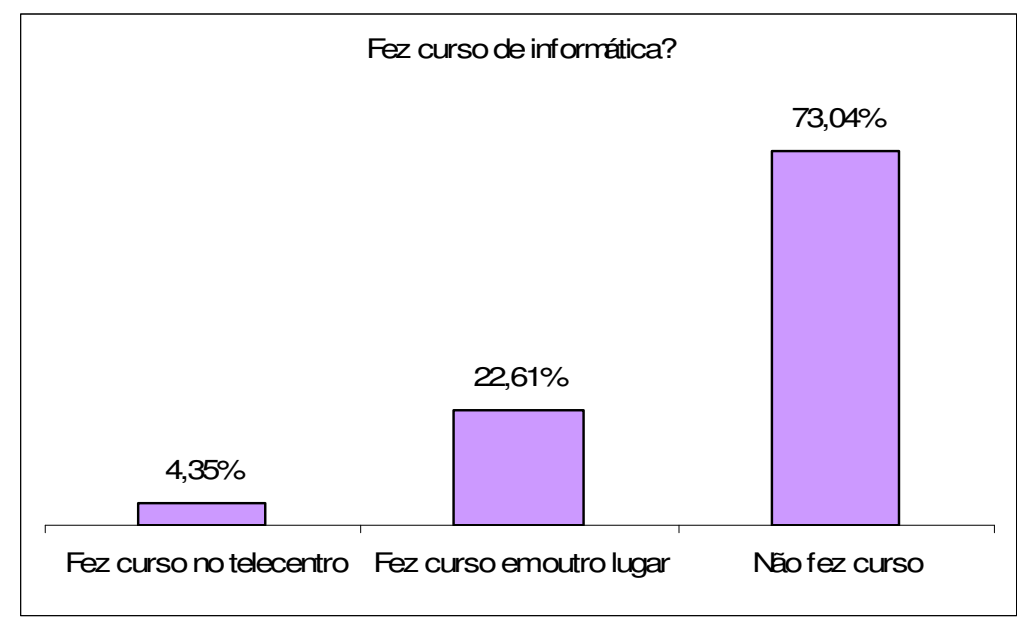

Ilustração 29 - Fez curso de informática?

A análise da ilustração 29 permite algumas leituras com relação aos motivos dessa diferença entre os perfis dos usuários: a) não existem muitos equipamentos no telecentro (somente 10), o que diminui a oferta por vagas nos cursos, b) a maioria das pessoas procuram o telecentro pela liberdade de uso e não pela oferta de algum tipo de instrução, c) por mais que o contato com o computador seja pequeno, todas as pessoas possuem conhecimentos e muitos dos usos que se faz das TICs são aprendidos de forma intuitiva.

Todos os usuários da amostra que declaram ter feito curso neste telecentro são adolescentes, faixa etária mais comum neste espaço.

Por último, ainda a respeito do perfil dos usuários entrevistados, é preciso constar que, apesar do telecentro estar em um centro cultural que oferece outros tipos de atividades e cursos (Artes, Pintura, Artesanato, Música, Dança e Teatro), a maioria dos entrevistados diz que não participa destas atividades, o que permite a verificação de que o espaço do telecentro ainda está em processo de incorporação da instituição e de ser incorporado por ela.

O grupo de pesquisadores do Nomads.usp, observando esse mesmo aspecto da separação entre as atividades desenvolvidas no local, ofereceu algumas oficinas para os educadores dos diversos cursos do centro cultural com intuito de familiarizá-los com as ferramentas digitais que poderiam ser utilizadas em seus cursos e oficinas.

Alguns alunos, inspirados por esse trabalho, fizeram seu cadastro no telecentro, porém esta pesquisa de campo não chegou a quantificar este número precisamente e apesar dos esforços que têm sido feitos, ainda não existe uma integração completa entre o espaço do telecentro e os demais módulos do programa e os projetos que a instituição coordena. 
Os responsáveis pelo telecentro verificam esta divisão e não a avaliam de forma positiva

Tem divisão. São poucos os que usam aqui e usam o espaço. exemplo, o pessoal dos cursos veio pra cá quando os professores vieram com a turma. há uma divisão mesmo. Pro espaço é ruim tanto aqui como pra fora porque a gente acaba num transformando tudo em uma coisa só. (Diego Amoroso - monitor do telecentro, em 24/07/2008).

porém, um fator positivo é a verificação de que o telecentro funciona muito bem como uma porta de entrada para pessoas novas no centro cultural. Muitas pessoas dizem que não sabiam que existiam cursos no local e que os descobriu depois que foi freqüentar o telecentro. 


\title{
6. Garantia de direitos e o aprendizado no telecentro
}

Vemos aqui que há aqui uma completa inversão, quando se compara esse tipo de educação com a educação formal, a qual possui um público definido e cativo. A educação não-formal precisa atrair e ser capaz de cativar os seus educandos para poder realizar o trabalho educativo. (SIMSON et al, 2004, p. 62).

A análise do perfil dos entrevistados, no capítulo anterior, permite observar que o telecentro estudado cumpre seus objetivos de possibilitar acesso gratuito às tecnologias digitais das pessoas menos privilegiadas, uma vez que a maioria não possui computador em casa ou não tem acesso fácil à rede. Porém, o acesso é somente o primeiro passo para a inclusão dessas pessoas no mundo digital. É preciso que elas incorporem as tecnologias utilizadas e as transformem em novos conhecimentos, sendo capazes de utilizar, de forma crítica, as ferramentas digitais e compartilhar saberes com outras pessoas.

Segundo Silveira (2001), “O manuseio, a elaboração e a compreensão dos softwares são instrumentos primários de uma política de inclusão e alfabetização tecnológica” (p. 29). Para o autor, o manuseio e a compreensão das ferramentas, possibilitados pelo acesso, devem contemplar, entre outros fatores, a aprendizagem cooperativa em rede; o desenvolvimento de múltiplas competências; obtenção de informações e geração de conhecimento.

Alguns autores resumem o desenvolvimento das habilidades citadas por Silveira com a utilização dos conceitos de alfabetização digital e letramento digital, que, muito parecidos com os termos utilizados para a aprendizagem da leitura e escrita, são termos cada vez mais utilizados na área das tecnologias. Segundo publicação do Centro de Estudos e Pesquisa em Educação, Cultura e Ação Comunitária (CENPEC),

\begin{abstract}
A palavra letramento vem se incorporando ao vocabulário da área da Pedagogia para conceituar um processo que vai além da decodificação do sistema alfabético da escrita e incorpora a compreensão dos usos sociais da escrita. Letramento digital, portanto, significa não apenas saber como utilizar as tecnologias digitais, mas entrar em contato com ele de maneira significativa, entendendo seus usos e possibilidades em nossa vida social. (BLASIS, BERTOCCHI, MELO, 2007, p. 12).
\end{abstract}

O termo letramento não anula a importância da alfabetização e vice-versa, mas, para alguns estudiosos, o desenvolvimento da habilidade de decodificar o sistema de escrita (alfabetização) não garante que as pessoas saibam ler e escrever com autonomia. Letramento pressupõe a utilização do conhecimento adquirido no processo de alfabetização aos usos sociais que fazemos da língua escrita. Assim, ainda sob a perspectiva de Blasis, Bertocchi e Melo, letramento digital pressupõe: 
manipular softwares navegadores; estabelecer critérios de pesquisa e conhecer ferramentas de busca adequadas; discernir sobre diferentes fontes de informação, entender sua autenticidade e compreender o sistema de hipertextos, bem como recursos de interatividade e comunicação. (CENPEC, 2006, p. 19).

Embora identifique certa diferenciação sobre a abordagem conceitual e histórica dos termos utilizados, verifico que tanto um como outro enfatizam que é necessário não só instrumentalizar as pessoas de alta tecnologia, mas fazê-las capazes de utilizar e produzir conhecimentos com estes recursos.

Dessa forma, podemos dizer que a idéia da alfabetização ou do letramento digital estão fortemente ligadas ao potencial comunicativo que as novas tecnologias possuem, pois esta característica se constitui em um dos principais usos sociais que fazemos destes recursos e, nesse sentido, podemos apontar o telecentro como um espaço que possibilita principalmente a garantia do direito de todos ao acesso aos meios tecnológicos e consequentemente à comunicação.

O espaço e os equipamentos do telecentro possibilitam, principalmente, que os usuários entrem em contato com uma nova forma de se relacionar e se comunicar, típicas do ciberespaço. ${ }^{69}$

\subsection{As relações sociais e a aprendizagem por meio da troca de informações}

No cruzamento de duas questões presentes no questionário, sendo uma que visava identificar a intenção de uso e outra que visava identificar a motivação para a freqüência ao telecentro, os usuários apresentam basicamente três respostas: I) a gratuidade (já comentada no capítulo anterior $^{70}$; II) $21,74 \%$ indicaram a comunicação (com utilização de correio eletrônico); e III) $68,70 \%$ indicaram o estabelecimento de relações (seja presencial ou por meio da utilização de recursos como Orkut e Chats). ${ }^{71}$

Essa terceira resposta é confirmada na fala de Cleidionéia (coordenadora do Projeto Casa Brasil na Instituição).

69 Na definição de Lévy (1999, p. 92, grifo do autor), ciberespaço é "o espaço de comunicação aberto pela interconexão mundial dos computadores e das memórias dos computadores. Essa definição inclui o conjunto dos sistemas de comunicação eletrônicos (aí incluídos os conjuntos de redes hertzianas e telefônicas clássicas), na medida em que transmitem informações provinientes de fontes digitais ou destinadas à digitalização".

70 O quesito gratuidade não estava originalmente elencado como uma questão no questionário de pesquisa, mas aparece a partir do cruzamento de variáveis.

71 Os números se referem à intenção de uso dos usuários no telecentro no ato do cadastro. A soma das porcentagens ultrapassa a $100 \%$ pois era permitido ao entrevistado indicar mais de uma resposta. Esses dados serão mais explorados ao longo do capítulo. 
Adolescentes vêm em busca de fazer contatos, aumentar seu grupo de amigos, descobrir as diferenças...(Cleidionéia Benedito coordenadora dos módulos do Casa Brasil na Instituição, em 31/07/2008).

Diego, monitor, que antes de assumir esta função era usuário de um outro telecentro, também aponta a existência da construção de relações interpessoais como motivação para a utilização do equipamento.

Então eu ia lá no curso e também pra ficar conversando com o Willi que desenhava na época muito bem e ai eu ia só pra conversar com ele também. Ás vezes eu ia só pra isso. (Diego Amoroso - monitor do telecentro, em 24/07/2008).

Ainda que este não seja um dos objetivos explícitos do Telecentro, portanto, não prevista no questionário de pesquisa, o espaço propicia o início de construção de laços afetivos e de amizade: essa relação é estabelecida pelo convívio e pela troca de informações presenciais.

Esta constatação corrobora estudos anteriores feitos na própria região (HIRAO, 2003) quanto à escassez de espaços destinados ao lazer, arte, cultura e esportes, fato este capaz de transformar qualquer iniciativa de caráter popular, social ou comunitário em espaço de socialização para a população infanto-juvenil local. ${ }^{72}$

Um exemplo das relações presenciais de troca de informações é dado pela declaração do monitor Diego. Segundo ele, na inauguração do telecentro havia uma regra de que as pessoas só poderiam fazer uso do computador isoladamente, não podendo trazer nenhum acompanhante ou amigo, mas essa norma precisou ser revista, conforme declara "Era muita gente querendo usar junto! Muitas pessoas vinham em dupla” (Diego Amoroso - monitor do telecentro, em 24/07/2008).

Já as trocas feitas na rede podem ser percebidas pelas declarações de alguns usuários:

Uso o telecentro pra me comunicar com os meus amigos, porque eu tenho amigos longe, porque eu já morei longe, entendeu? Então eu converso com eles... pelo Orkut (Caroline, 15 anos).

Eu coloquei um monte de gente estranha no meu Orkut porque é interessante você ver que tem gente diferente, a pessoa vive em um lugar diferente, fala diferente... (Marcelo, 25 anos).

72 No início de 2005, tive a oportunidade de atuar nas pesquisas diagnósticas do Projeto Fábricas de Cultura na Zona Leste de São Paulo. O diagnóstico das instituições culturais feito pela Secretaria de Estado da Cultura de São Paulo em parceria com o Instituto Pombas Urbanas mapeou as organizações sociais que realizam atividades culturais existentes nos distritos de Cidade Tiradentes, Sapopemba, Vila Curuçá e Itaim Paulista. 
Além da interação interpessoal reconhecida acima nas declarações dos monitores e usuários, a pesquisa de campo também permitiu a verificação de outros tipos de interação.

Quando perguntados sobre a forma com que adquiriram os conhecimentos de informática para utilizarem o espaço, os usuários respondem de forma bem diferenciada: $24,26 \%{ }^{73}$ declaram que fizeram um curso de informática, $23,67 \%$ dizem que aprenderam com os monitores do telecentro no horário do acesso livre, 19,53\% aprenderam com amigos e parentes e a maioria $(32,54 \%)$ declara ter aprendido a utilizar as ferramentas do telecentro sozinho, apenas utilizando o computador.

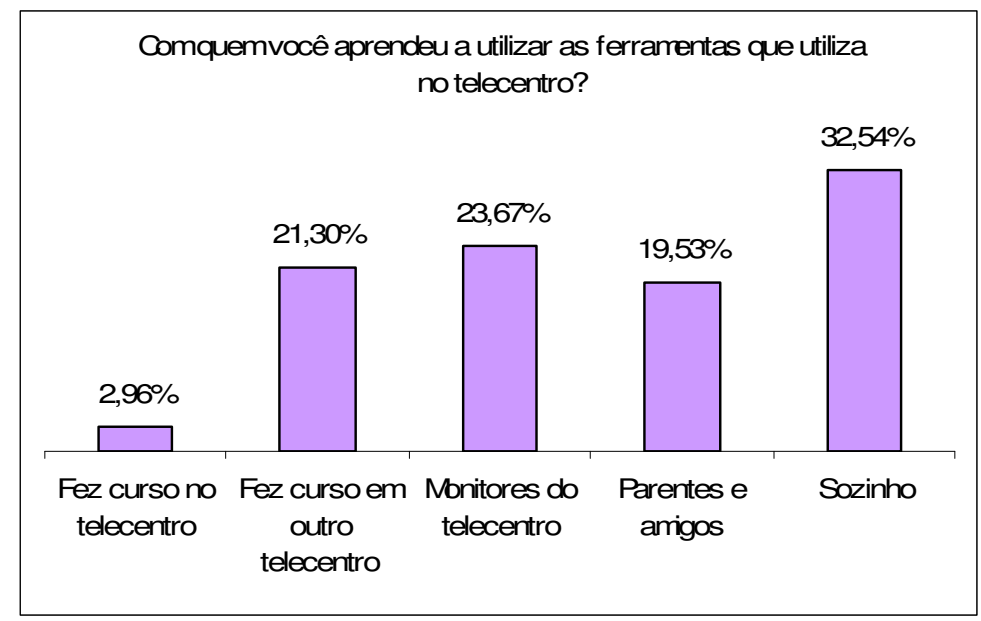

$\underline{\text { Ilustração } 30}$ - Com quem você aprendeu a utilizar as ferramentas que utiliza no telecentro? ${ }^{74}$

A análise destes dados permite a verificação de que as aprendizagens que ocorrem no local são possibilitadas por diferentes tipos de interação: educador-educando (cursos e oficinas), interação interpessoal (amigos, parentes e monitores) e interação usuário-máquina (aprendi sozinho).

Esses diferentes tipos de interação existentes no local, bem como a comunicação possibilitada por eles, reforça a hipótese de o telecentro ser espaço de Educação Social. Isso porque, as características apontadas por Graciani (2006) para lugares de educação social podem ser encontradas no lugar.

A pedagogia social caracteriza-se pois, como um projeto radical de transformação política e social, uma vez que: a. propõe inicialmente criar uma teoria renovada de relação homem,

73 Soma das porcentagens dos que fizeram curso fora do telecentro e no telecentro.

74 A soma das respostas dadas ultrapassa a $100 \%$ pois era permitido ao usuário responder mais de um item, o que significa que boa parte deles indicou mais de uma forma de aprendizagem: sozinho e com os amigos, curso e sozinho etc. 
sociedade e cultura, com uma ação pedagógica que pretende fundar, a partir do exercício em todos os níveis e modalidades da pratica social, uma educação libertadora; (GRACIANI, 2006, grifo nosso).

Apesar desses primeiros dados apontarem a existência de interações e vivência das práticas sociais no telecentro, é preciso ainda se perguntar se essas relações permitem algum tipo de aprendizagem real para o letramento digital ou somente possibilitam uma familiarização dos usuários com os recursos tecnológicos: Em que medida o acesso aos recursos digitais e as interações estabelecidas no telecentro possibilitam um uso com competência das ferramentas disponibilizadas? Existe aprendizado? De quais conteúdos?

$\mathrm{Na}$ tentativa de responder a essas perguntas, a segunda parte do questionário aplicado aos entrevistados, buscou a verificação da utilização, por parte dos usuários, de alguns recursos disponibilizados pelo telecentro.

\subsection{Da intenção à real utilização: o que os usuários exploram no telecentro.}

Com o intuito de verificar os usos que as pessoas fazem das ferramentas no telecentro comunitário, a fim de refletir sobre os interesses que as motivam e que tipo de conteúdos são aprendidos neste espaço, foram feitas duas perguntas aos entrevistados: $O$ que pretendia utilizar no telecentro quando veio fazer o cadastro? e $O$ que mais utiliza quando utiliza o horário do acesso livre o telecentro?

As respostas foram agrupadas em oito áreas a fim de facilitar a interpretação dos dados: comunicação, instrução, interesse profissional, jogos, relacionamentos, trabalhos escolares, E-gov e informações. Os tipos de respostas encontradas em cada uma das categorias estão descritos na tabela abaixo: 


\begin{tabular}{|c|c|}
\hline Categoria & Respostas dos usuários \\
\hline Comunicação & $\begin{array}{l}\text { - } \quad \text { utilização de correio eletrônico } \\
\text { - } \quad \text { aplicativos de mensagens instantâneas (MSN, GAIM etc) }\end{array}$ \\
\hline Instrução & $\begin{array}{l}\text { - } \quad \text { busca por cursos a distância (EaD) } \\
\text { - } \quad \text { oficinas e cursos de informática no próprio telecentro }\end{array}$ \\
\hline Interesse profissional & $\begin{array}{l}\text { - procura por emprego } \\
\text { - elaboração e envio de currículos }\end{array}$ \\
\hline Passatempo & - Jogos \\
\hline Relacionamentos & $\begin{array}{l}\text { - } \quad \text { sites de relacionamentos (Orkut) } \\
\text { - Chats }\end{array}$ \\
\hline Trabalhos escolares & - pesquisa para trabalhos escolares \\
\hline E-gov & - $\quad$ serviços públicos diversos \\
\hline Informação & $\begin{array}{l}\text { - leitura de jornal e revista } \\
\text { - }\end{array}$ \\
\hline
\end{tabular}

Após a organização dessas categorias, foi possível agrupar todas as respostas em um único gráfico.

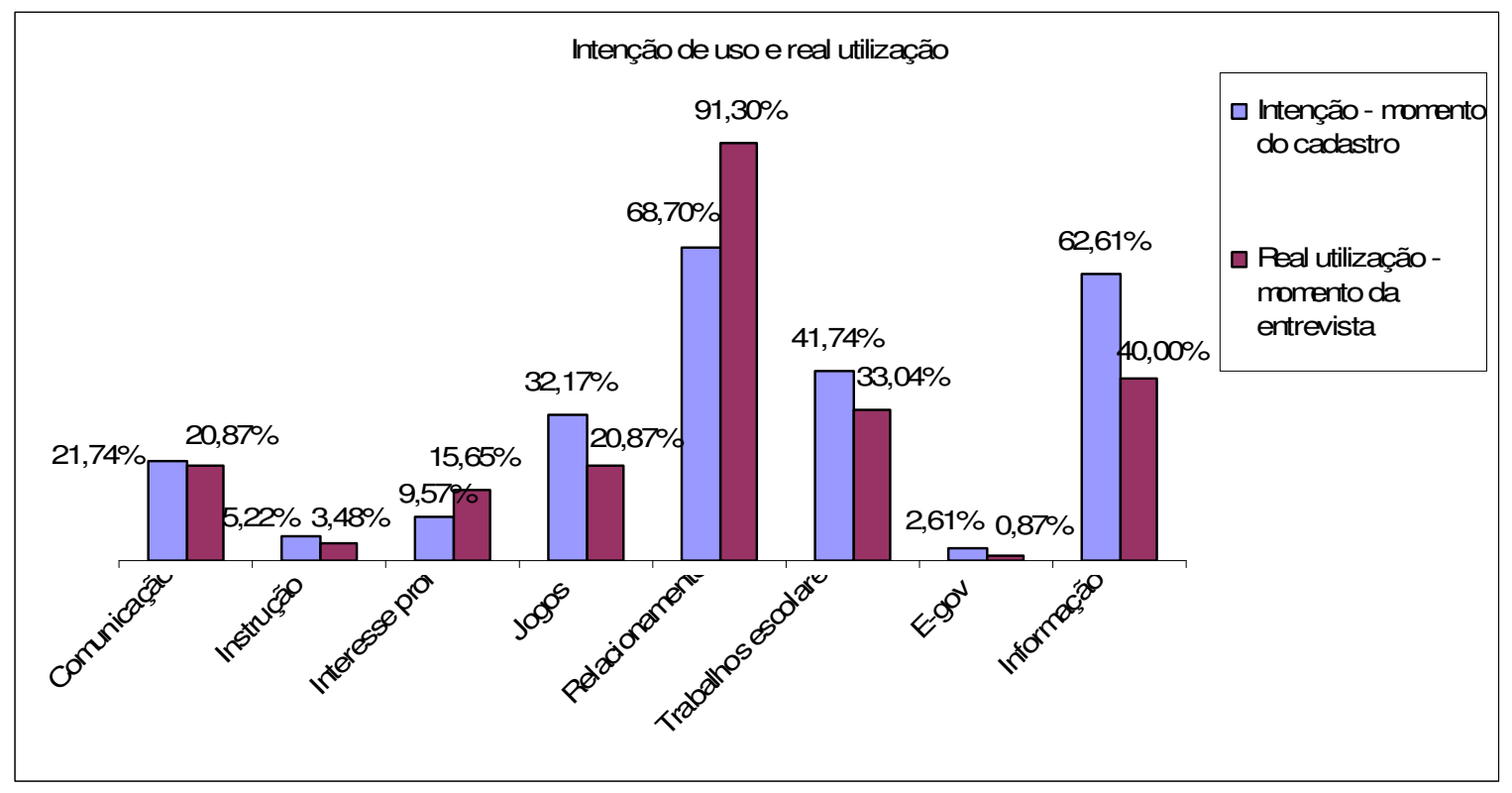

Ilustração 31 - Intenção de uso e real utilização ${ }^{75}$

Os dados obtidos são distintos nos dois momentos questionados: ato do cadastro e momento da entrevista. Isso possibilita analisar que a intenção de uso (desejo) do usuário com relação aos equipamentos se modifica com o tempo de uso e freqüência ao espaço.

\footnotetext{
${ }^{75}$ A soma das respostas dadas ultrapassa a $100 \%$ pois era permitido ao usuário responder mais de um item, o que significa que boa parte deles indicou mais de uma forma de aprendizagem: sozinho e com os amigos, curso e sozinho etc.
} 
Em somente duas das categorias (relacionamentos e interesse profissional) é possível verificar um aumento no número de respostas entre os que pretendiam utilizar as ferramentas destas categorias e os que de fato as utilizam.

Na categoria relacionamentos, essa melhora é verificada pela análise do item anterior, com relação ao uso de sites como o Orkut, cada vez mais comum e freqüentado pelas pessoas, principalmente os adolescentes.

$\mathrm{Na}$ categoria interesses profissionais é possível compreender essa melhora observando o próprio perfil dos usuários entrevistados e a realidade da comunidade em que o telecentro está inserido: segundo o Observatório Cidadão (2006), Cidade Tiradentes está entre as regiões com piores índices de desempregos na cidade de São Paulo, tendo cerca de 17,80\% de sua população desempregada $^{76}$. Os usuários entrevistados confirmam esta estatísticas uma vez que, dos 115 usuários entrevistados, $8,7 \%$ se declara desempregado, porém, considerando somente as pessoas com idade para trabalhar (jovens e adultos) no cálculo deste percentual, o número aumenta para $28,57 \%$.

A análise desses dois dados permite traçar a hipótese de que o uso das ferramentas no telecentro possibilita a percepção de que existem recursos para se relacionar com outras pessoas e para procurar emprego que antes os usuários não conheciam - no ato do cadastro não tinham a intenção de utilizar e passam a utilizar por necessidade ou porque conhecem o recurso e se interessam por ele.

Se considerarmos novamente a questão do letramento digital (usos sociais que fazemos das tecnologias), é possível arriscar uma análise com relação a esta questão: quando maior o uso social que se faz da ferramenta, mais significativa ela se torna para os usuários. A afirmativa inversa desta hipótese também pode ser verdadeira: quanto mais significativa a ferramenta tecnológica é para o usuário, mais ele fará uso dela.

Nos demais itens apontados na aplicação do questionário, onde aparece um declínio do número de usuários que se declaravam interessados em utilizar as ferramentas e que de fato fazem uso dela, podemos apontar alguns motivos, quando verificamos as declarações dos usuários e também dos funcionários do telecentro.

O telecentro sofreu o furto de todos os equipamentos antes mesmo de ser inaugurado em Abril de 2007. Apesar do desfalque de materiais, a data de inauguração foi mantida com a colaboração da Cooperjovem uma instituição que forneceu computadores montados em oficinas de

76 Observatório Cidadão. Disponível em $<$ http://www.nossasaopaulo.org.br/observatorio/regioes.php?tema=11\&indicador=48\&regiao=22> Acesso em: set 2008. 
Metareciclagem. Nem todos os computadores funcionam perfeitamente e, muitas vezes, os usuários enfrentam problemas para utilizar as ferramentas que desejam, como declaram Diego e Caroline:

Quando a gente abriu aqui era muito jogo, tanto que era toda hora travando o computador porque os jogos eram muito pesados. Agora nem tanto por causa das máquinas novas que tem servidor próprio, mas quando eram todas as máquinas ligadas num só servidor, quando todas elas travava com jogos, travava tudo. (Diego Amoroso - monitor do telecentro).

Mas a conexão tá ruim... demora muito. Demora muito para usar, para carregar...(Caroline, 15 anos).

Assim, a análise dessas primeiras respostas indicam que a intenção inicial de utilização das ferramentas disponibilizadas no telecentro é diferente do real uso que os usuários fazem do espaço. Diversos fatores se colocam em questão, mas dois deles se destacam, sendo um a favor da melhora (uso social da ferramenta - relacionamentos e procura por emprego) e outro contra (infra-estrutura inadequada ou insuficiente para atender às intenções de uso das pessoas).

\subsection{A relação entre frequiência de uso e os recursos disponibilizados no telecentro}

A fim de aprofundar os dados obtidos no item anterior, havia na segunda parte no questionário aplicado, uma proposta de investigação, por meio da percepção dos próprios usuários, sobre a existência ou não de mudança de comportamento com relação a nove serviços que o acesso livre possibilita.

As respostas eram fechadas e cada entrevistado tinha a opção por quatro alternativas:

- Nada (Não faz uso);

- Pouco (usa, mas não muito);

- Razoável (faz uso, mas não é freqüente);

- Muito (utiliza com freqüência).

Os entrevistados foram perguntados sobre como era o uso (frequiência) que faziam de tais recursos antes de conhecer o telecentro e agora, com a utilização do mesmo. O objetivo era comparar as respostas e verificar se havia algum tipo de melhora com o tempo de uso, ou seja, se com a utilização das ferramentas, a freqüência de utilização de cada uma delas aumentava ou não.

Em todos os aspectos observados (utilização de e-mail; pesquisas diversas; serviços 
públicos; participação em comunidades pela Internet; leitura de notícias; participação em fóruns de discussão; procura por emprego; diversão, lazer; trabalhos escolares), é interessante notar que, na graduação de Nada para Muito, existe uma inversão nas respostas nos dois momentos: antes de conhecer e freqüentar o telecentro e depois de se cadastrar e fazer uso do mesmo.

Esta análise geral das respostas permitiu a verificação de que existe melhora na utilização das ferramentas disponibilizadas no telecentro, o que demonstra que o acesso, por si mesmo já se constitui em uma forma de aprendizado uma vez que as pessoas passam a conhecer recursos que antes não utilizavam ou explorava com pouca freqüência. Os entrevistados declaram que antes de freqüentar o telecentro comunitário faziam pouco uso dos equipamentos e ferramentas pesquisados e depois de um tempo de uso, declaram que utilizam com mais freqüência.

É importante, contudo, observar cada uma das respostas, analisando suas causas e particularidades. Os dados obtidos foram agrupados conforme a natureza dos recursos pesquisados $^{77}$. Este agrupamento é diferente das categorias traçadas no Item 5.2. por se tratar de uma análise mais específica com relação a apenas algumas ferramentas.

\subsubsection{Utilização do e-mail}

Na tentativa de investigar uma das principais funções do telecentro comunitário que é o acesso à comunicação por meio das tecnologias digitais, os entrevistados foram perguntados sobre a principal ferramenta de comunicação pela Internet: o correio eletrônico (e-mail).

A maioria (50,43\%) afirma que antes de conhecer o telecentro não possuía (não fazia uso) ou usava pouco $(24,35 \%)$ o correio eletrônico. Esses números mudam quando perguntados como está a utilização deste recurso com o telecentro e suas ferramentas disponíveis. ${ }^{78}$

77 Foram pesquisados dez itens, porém um deles foi desconsiderado nesta análise por respeitar os resultados do préteste realizado, conforme consta no capítulo3.

78 os usuários entrevistados já faziam uso do telecentro há pelo menos cinco ou seis meses. 


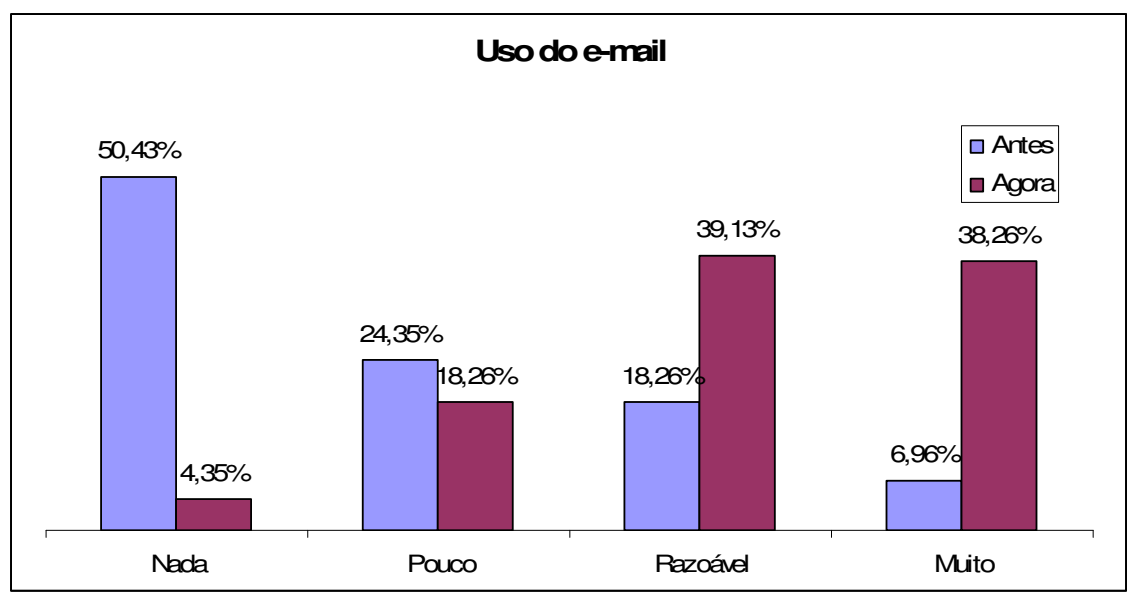

Ilustraç̃o 32 - Uso do e-mail

O gráfico mostra que o número de usuários que declara não utilizar o e-mail diminui de $50,43 \%$ para $4,35 \%$ ao mesmo tempo em que os usuários que declaram utilizar Muito aumenta de $6,96 \%$ para $30,26 \%$.

Os números confirmam que o acesso ao telecentro possibilita a melhora da utilização das ferramentas de comunicação e permitem traçar a hipótese de que: se antes o usuário não utilizava o e-mail e agora utiliza, ele aprendeu a fazer uso deste recurso no espaço do telecentro. Isso ocorre principalmente pelo fato de que antes da utilização do espaço, muitos usuários não conheciam o recurso do e-mail, não viam uma finalidade para ele ou ainda não tinham outro lugar para acessar.

A comunicação, mediada por correio eletrônico ou outras formas presentes nas respostas já citadas no Item 5.2., é um forte indício de que informações estão sendo trocadas no espaço virtual visitado a partir do telecentro.

Seria a transmissão de informações a primeira função da comunicação? Decerto que sim, mas em um nível mais fundamental o ato de comunicação define a situação que vai dar sentido às informações trocadas. (LÉVY, 1993, p. 21) [...] O jogo da comunicação consiste em, através de mensagens, precisar, ajustar, transformar o contexto compartilhado pelos parceiros. (p. 22).

\subsubsection{Leitura de notícias pela Internet}

Com intuito de investigar melhor as formas de circulação da informação no ciberespaço acessado pelo telecentro e verificar se os meios de comunicação e informação em formato digital 
são lidos, os entrevistados foram perguntados se costumam ler notícias pela Internet.

Os resultados são um pouco distintos da pergunta anterior, uma vez que a melhora da utilização deste recurso não está tão aparente. Muitos usuários declaram que não costumam ler notícias pela Internet por fazerem isso através de outros meios de comunicação, tais como: revistas, jornais e principalmente a televisão e o rádio.

Apesar da pouca melhora neste item, é possível constatar que os que declararam que não lêem Nada pela Internet diminui de 66,96\% para 29,57\% e os que liam Muito passam de 5,22\% para $19,13 \%$, o que indica que os recursos digitais podem se tornar uma fonte de informação para as pessoas que têm acesso a eles.

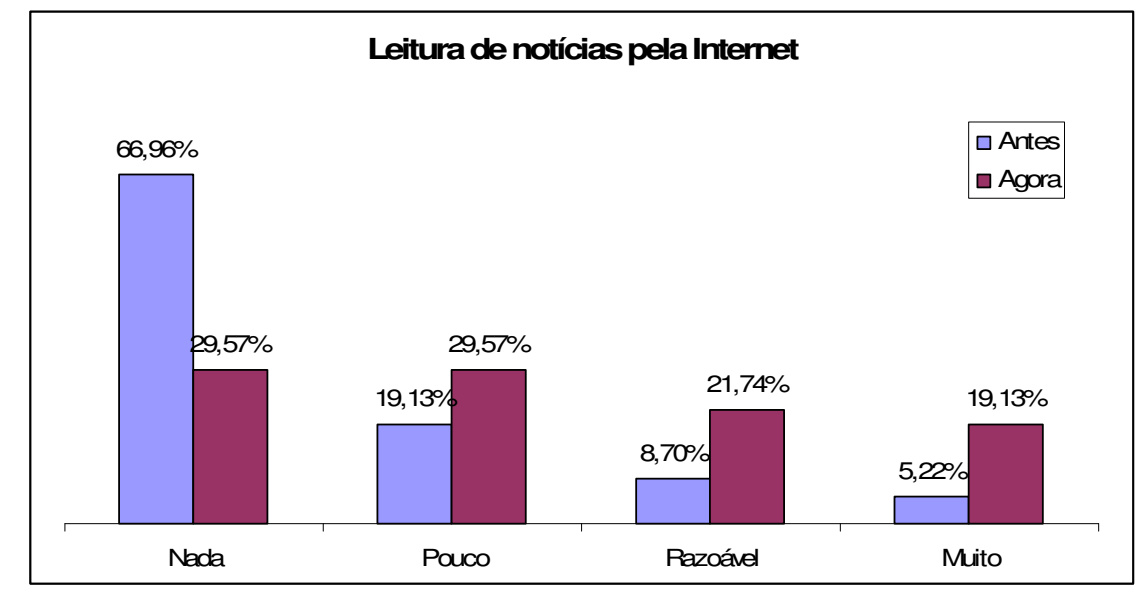

Ilustração 33 - Leitura de Notícias pela Internet

Porém, é importante destacar, na análise destes dados, o fato de muitos, apesar de possuírem certa escolaridade, terem problemas com relação à leitura e escrita, resultado de processos de alfabetização impróprios, realidade freqüente nas escolas públicas paulistas.

O Saresp mostra que $31,3 \%$ de 4,5 milhões de alunos da $1^{\mathrm{a}}$ série do ensino fundamental terminam o ano letivo sem saber ler ou escrever. Segundo o estudo, $18 \%$ dos alunos saem da $2^{a}$ série sem saber ler e escrever. No ano passado, o índice de alunos quer terminaram a $1^{\mathrm{a}}$ série sem saber ler ou escrever foi de $25 \%$. (Diário de São Paulo apud. OAB, 2005).

Dessa forma, podemos analisar os dados do gráfico de duas maneiras. Na primeira, observando que há pouca utilização da Internet para a leitura de notícias devido ao pouco hábito de leitura entre as pessoas na comunidade - preferem buscar notícias por meios de comunicação que se utilizam da linguagem oral para veiculação das informações como o rádio e a televisão. Na segunda, podemos apontar uma visão mais otimista, pontuando que existe melhora na utilização das 
tecnologias para a leitura de notícias, o que pode apresentar esses recursos como um estímulo para o hábito da leitura.

Porém, tanto uma leitura como a outra permitem a reflexão de que a linguagem digital, utilizada no ciberespaço depende, e muito, da linguagem escrita, pois, ainda que recursos de voz e vídeo já estejam popularizados na rede, muitas informações são veiculadas a partir de textos escritos.

\subsubsection{Diversão e Lazer}

Alguns usuários declaram que usam o telecentro para diversão e lazer, classificando os jogos e a busca por músicas e vídeos nesta área.

Quando perguntados sobre a frequiência com que utilizam esse tipo de recurso, as respostas apresentadas se assemelham às dadas no item Uso do e-mail.

Antes da utilização do telecentro, a maioria declara que não fazia uso $(38,26 \%)$ ou usava pouco $(25,22 \%)$. Com o telecentro, $50,43 \%$ dos entrevistados indica que utiliza bastante este tipo de aplicativo e/ou ferramenta.

É importante observar que as pessoas que declaram utilizar os recursos de diversão e lazer antes do telecentro afirmam que tinham como espaço para esse tipo de utilização as Lan Houses e que agora elas podem fazer em um espaço gratuito.

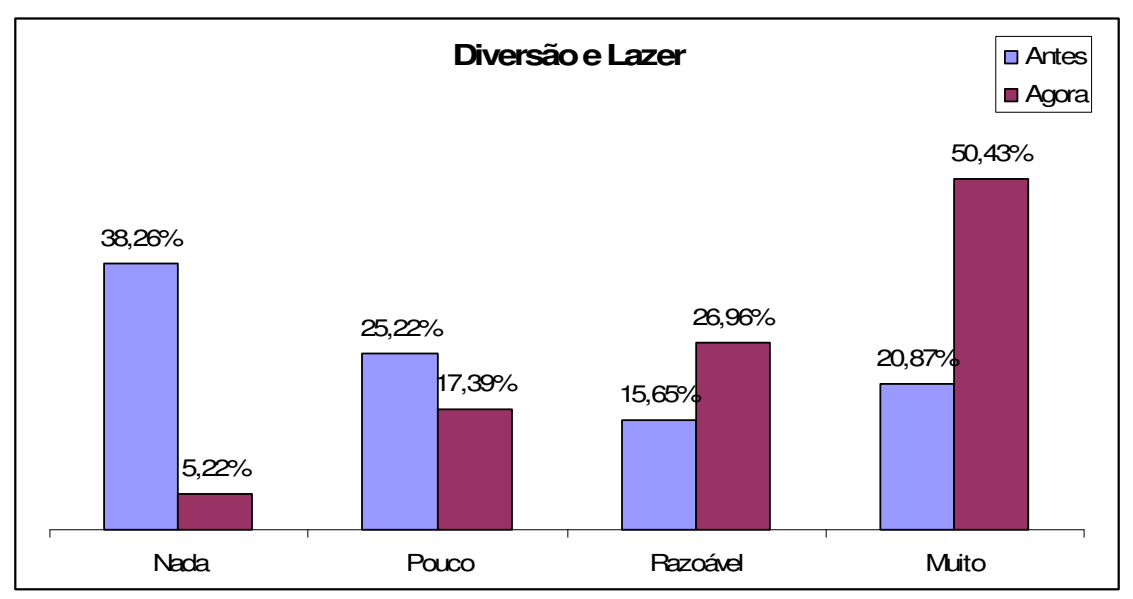

Ilustração 34 - Divisão e Lazer 


\subsubsection{Trabalhos escolares}

No item Trabalhos Escolares, o gráfico encontrado também apresenta uma semelhança ao 4.3.1. por apresentar melhora na freqüência na utilização dessa atividade.

Os 26,96\% que declaravam já fazer uso intensivo das tecnologias para a pesquisa e elaboração de trabalhos escolares aumentam para 40,87\% com a utilização do telecentro.

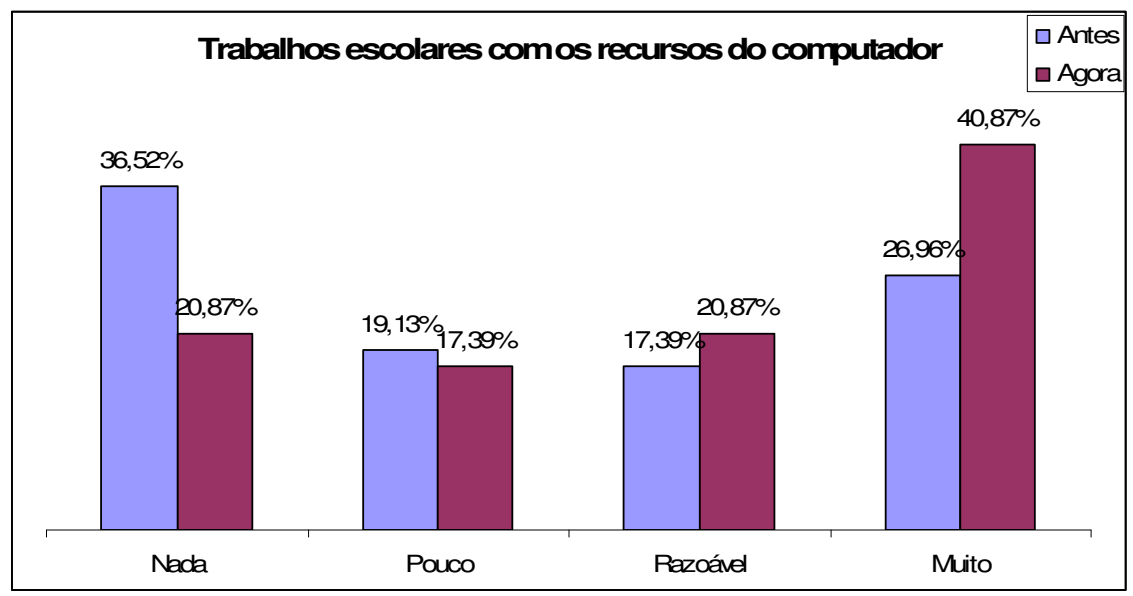

Ilustração 35 - Trabalhos escolares com os recursos do computador

Ainda existem 20,87\% que declaram que mesmo com o telecentro não fazem uso desse serviço. Isso porque pouco mais de $13 \%$ dos entrevistados não são mais estudantes.

A respeito dos trabalhos, os usuários declaram que fazem pesquisas pela Internet sobre o conteúdo solicitado pelos professores e também utilizam ferramentas como editor de texto para a digitação e formatação de seus trabalhos. O telecentro permite a impressão de até duas folhas por usuário em cada acesso livre.

Declarações como as de Caroline, 15 anos, auxiliam na compreensão de como as pesquisas são feitas.

Caroline: Pesquiso trabalho da escola que a professora passa porque ai você vai na internet e pesquisa lá que é mais rápido. Pesquisadora: Como você pesquisa? Caroline: Ah! tem um site ai, o google, você conhece?

A facilidade de acesso às informações por meio da Internet (é mais rápido) tem atraído os estudantes para realizarem suas pesquisas neste espaço porém, é preciso considerar que uma análise crítica dos conteúdos é fundamental para que haja aprendizagem significativa por parte dos estudantes.

Lévy (2001) afirma que esse tipo de questionamento não é uma peculiaridade da Internet, mas deve ser feito com todos os tipos de veículos da informação. 
Não é porque uma coisa está impressa que é verdadeira. [...] Não é porque vimos uma coisa na TV que ela é verdadeira. [...] Com a linguagem, podem-se fazer tantas mentiras, tantas interpretações falsas, tantas manipulações... Portanto, somos confrontados a esse problema de todas as formas, com ou sem Internet, não? (LÉVY, 2001).

O autor ainda pontua que a Internet como fonte de informação não funciona apenas como uma biblioteca "um estoque de textos", pois se constitui em um meio de comunicação entre as pessoas. Para ele, a superficialidade das informações pode ser minimizada com a vivência dessa comunicação.

se você participar de vários grupos de discussão, se você conhecer todos os cantos dos sites da web que lhe interessam, se participar da fabricação desse imenso hiperdocumento coletivo, fazendo seu próprio site, criando ligações com os sites interessantes, etc. isso não é superficial. Superficial é a implicação que você pode ter ou não com este espaço. (idem)

\subsubsection{Cidadania e participação}

Concordando com a afirmação de Lévy apresentada no item a cima, o questionário também procurou pesquisar a questão da participação dos usuários em Fóruns de discussão e comunidades on-line.

Nesses itens, não houve melhora tão expressiva dos números com relação aos dois momentos pesquisados (antes e agora).

Perguntados sobre a participação em comunidades on-line, 67,83\% dizem que não faziam uso desse tipo de serviço antes de se cadastrarem. Esse número cai para 15,65\% com a utilização do telecentro. Ao mesmo tempo, os $8,7 \%$ que participavam de comunidades antes do telecentro, cresce para $32,17 \%$ com este equipamento. 


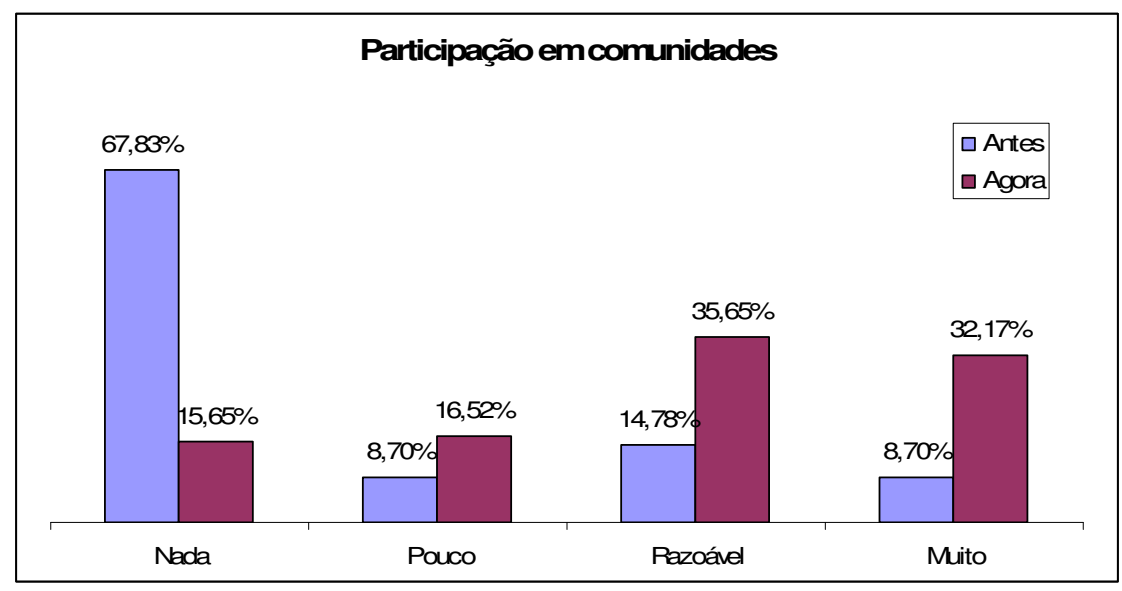

Ilustracão 36 - Participação em comunidades on-line

Apesar de existir uma melhora no gráfico, é preciso fazer uma análise crítica com relação a este item, uma vez que boa parte dos entrevistados que declara participar de comunidades on-line, dizem que participa no Orkut. Em geral, a participação em comunidades neste website de relacionamentos se trata apenas de um grupo com interesses semelhantes que não necessariamente faz uso de mecanismos de comunicação, interação e discussão de temas mais aprofundados.

Esse dado se confirma na análise das respostas do item Participação em Fóruns de Discussão, onde as respostas não variam de um momento a outro, ou seja, os usuários não passam a utilizar mais este recurso com a freqüência ao telecentro.

O número de usuários que declara não fazer nenhum tipo de uso desse recurso cai de $85,22 \%$ para $73,91 \%$ com a utilização do telecentro, porém esta diferença não é muito representativa se colocarmos em números absolutos.

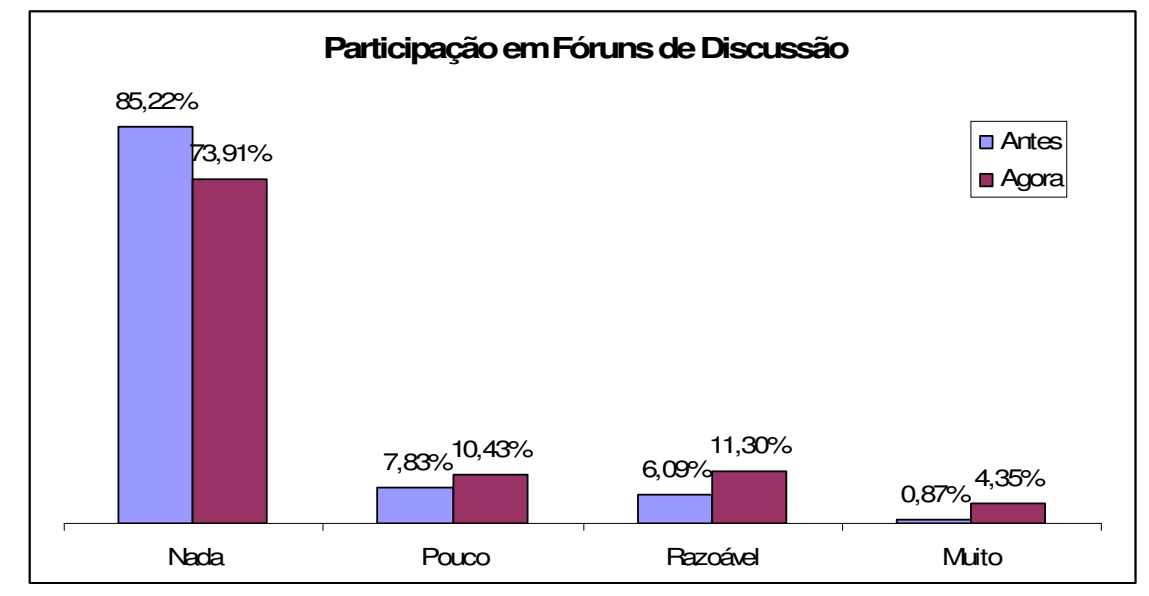

Ilustração 37 - Participação em Fóruns de Discussão

A análise desses dois dados apontam para três hipóteses possíveis: a primeira é a de que o 
fato de não haver melhora nos itens apresentados se dá pelo pouco tempo de uso do telecentro, pois todos os entrevistados só estavam freqüentando o lugar há cinco ou seis meses. Esta primeira hipótese de interpretação permite a reflexão sobre a complexidade de algumas ferramentas. Se existem ferramentas e serviços que apresentam melhora expressiva com a utilização do telecentro, por que com estes itens não ocorre o mesmo?

A segunda hipótese possível surge desse questionamento e permite a suposição de que existem conteúdos que necessitam de mais tempo de uso para serem aprendidos ou ainda que o usuário aprende a utilizar com autonomia muitos recursos, mas alguns recursos precisam ser apresentados a ele, pois somente o acesso livre não possibilita o conhecimento e a apropriação desse tipo de ferramenta.

A terceira hipótese para esses dados vem ao encontro do que foi refletido no início deste capítulo sobre letramento digital, ou dos usos sociais que fazemos das ferramentas digitais disponíveis. Seguindo essa linha de análise, podemos imaginar que as pessoas não participam de fóruns e comunidades on-line porque não necessitam disso ou não vem nesse tipo de serviço alguma utilidade e/ou razão para sua vida.

Infelizmente a pesquisa de campo não conseguiu coletar dados conclusivos para nenhuma das hipóteses citadas. Isso porém, não impede a percepção de que é necessário um trabalho educativo se o telecentro pretende atuar no eixo de participação e construção coletiva de saberes na rede, pois o acesso livre por si mesmo não possibilita a evolução deste tipo de conteúdo.

Para que o usuário tome conhecimento e faça uso de ferramentas de participação, antes mesmo de identificá-la como importante, ele precisa conhecê-la. É preciso que haja por parte da instituição, dos funcionários e também dos usuários a compreensão de que "A aprendizagem em rede é cooperativa e ao interagir, obtendo e gerando hipertextos, se está praticando e desenvolvendo uma inteligência coletiva”. (SILVEIRA, 2001, p. 29). Neste ponto, porém, acredito que é importante ir na raiz do problema e observar que na nossa cultura e durante a formação escolar são raros os projetos e programas que valorizam a participação e que estimulam a aprendizagem por meios colaborativos.

Apesar de apontar no Item 5.1. que existe troca de informações e aprendizado por interação, não é possível concluir, com os dados apresentados nesta pesquisa, que este telecentro possibilita a formação de cidadãos mais reflexivos e atuantes, capazes de dialogar com outras pessoas e construir redes de interesses e mobilização social, o que não minimiza a importância de sua existência nessa comunidade.

O telecentro permite a possibilidade de acesso a ferramentas e conteúdos e este é o primeiro 
passo para a inclusão digital e também para a participação das pessoas no mundo virtual. Neste item ainda, é preciso considerar outra questão: a utilização de serviços públicos disponibilizados na Internet.

Perguntados sobre a utilização desse tipo de serviço, a maioria dos entrevistados $(90,43 \%)$ diz que não utilizava Nada antes de se cadastrar no telecentro, mas este número não diminui consideravelmente após o cadastro $(77,39 \%)$. O número de usuários que declara fazer uso constante desta ferramenta no telecentro é de apenas $3,48 \%$.

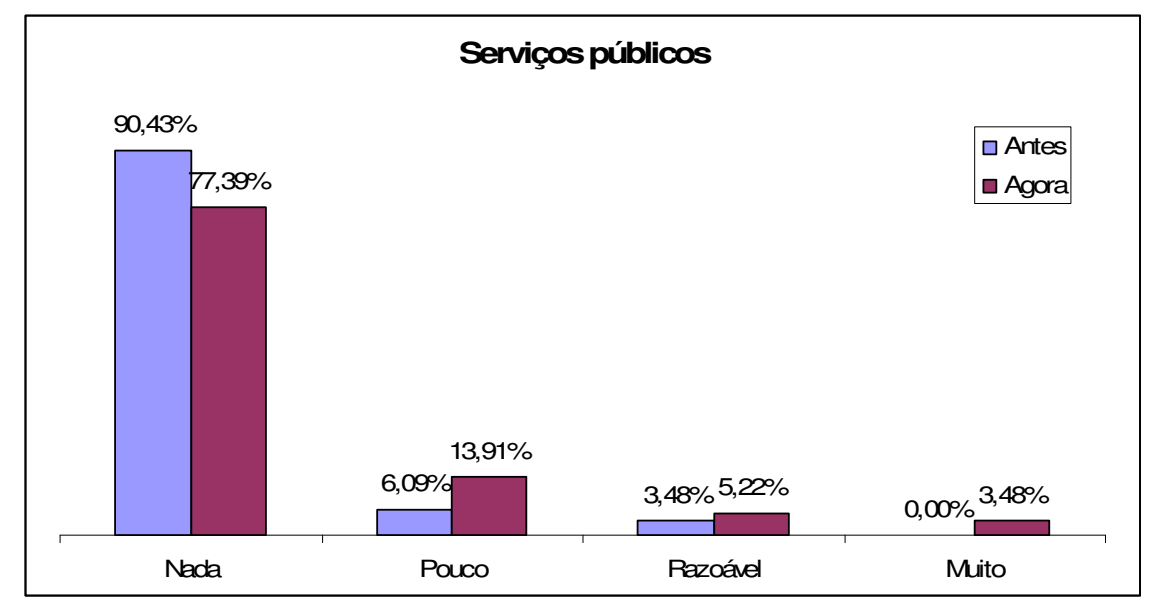

Ilustração 38 - Serviços públicos

O monitor Diego, na entrevista, aponta um dado diferente dos encontrados nessa análise dos questionários. Ele declara que esse tipo de serviço é um dos mais procurados pelas pessoas no telecentro.

Pesquisadora: $O$ que as pessoas mais procuram aqui no telecentro?

Diego: Primeiro vem o Orkut, com certeza! Depois vem as crianças com os jogos e em terceiro, vem as pessoas pra algum tipo de serviço público.... pra CPF, fazer cadastro de CPF, ou então o neto veio ver alguma coisa pra vó da aposentadoria... alguma coisa de cadastro...

A diferença entre os dados do questionário e a entrevista com o monitor pode ser atribuída ao fato de que a amostra, escolhida de forma aleatória, foi composta em sua maioria por crianças e adolescentes. Esse dado da faixa etária possibilita a percepção de que pode não haver a necessidade da utilização de serviços públicos pelos entrevistados, o que não significa que os demais usuários não fazem uso desses serviços.

Apesar de utilizarem os serviços públicos como afirma o monitor Diego, é preciso pontuar que esse tipo de serviço não é procurado por boa parte dos usuários de Internet no Brasil. Segundo a Pesquisa sobre o uso das tecnologias da Informação e da comunicação no Brasil 200, 25\% dos 
usuários da Internet não haviam usado os serviços do governo eletrônico há pelo menos 12 meses. (BALBON, 2008, p. 183)

Os principais motivos apresentados pelos internautas entrevistados pela pesquisa são: 49\% prefere fazer contato pessoalmente; $15 \%$ declara ter preocupação com proteção ou segurança; $13 \%$ diz que o custo é alto; $13 \%$ contato com a administração pública via Internet é complexo; $8 \%$ declara que os serviços que precisa não estão disponíveis na Internet. (Idem, p.196,197) ${ }^{79}$

Esses dados, juntamente com as afirmações do monitor Diego

\begin{abstract}
Pesquisadora: Você costuma auxiliar quando as pessoas vêm a procura de serviços públicos pela Internet? Diego: às vezes alguém pede pra eles só que num passa o endereço, então a gente tem que chegar aqui e tem que pesquisar o endereço que há endereços específicos da prefeitura. Tanto que eu nem conhecia antes. Acabei conhecendo de tanto ajudar aqui. Pesquisadora: São serviços fáceis de serem encontrados? Diego: Muitas vezes não porque às vezes eu até num acho porque eles usam uns termos meio diferentes, uns termos complicados, que num tá no cotidiano.
\end{abstract}

demonstram que, apesar de algumas pessoas verificarem a facilidade que os serviços públicos online possibilitam, nem sempre eles estão de acordo com as necessidades e linguagem das pessoas que os utilizam. Foram desenvolvidos para uma parcela mínima da população e não garantem o exercício da cidadania por parte de todos, uma vez que a grande maioria não faz uso deles e quando o fazem não possuem autonomia ou não ficam satisfeitas com o atendimento.

\title{
6.3.6. Procura por empregos
}

No item Procura por emprego, os dados obtidos com os questionários e entrevistas são semelhantes aos encontrados no item anterior. Nos questionários, 88,70\% declara que não costumava procurar emprego pela Internet antes do telecentro e esse número não diminui significativamente com o uso do espaço $(73,91 \%)$. Apenas $13,91 \%$ diz que faz uso constante desse serviço no telecentro.

79 A questão permitia múltiplas respostas. Considerando que não apresento todas as respostas , é necessário observar que a soma de todas elas ultrapassa a $100 \%$. 


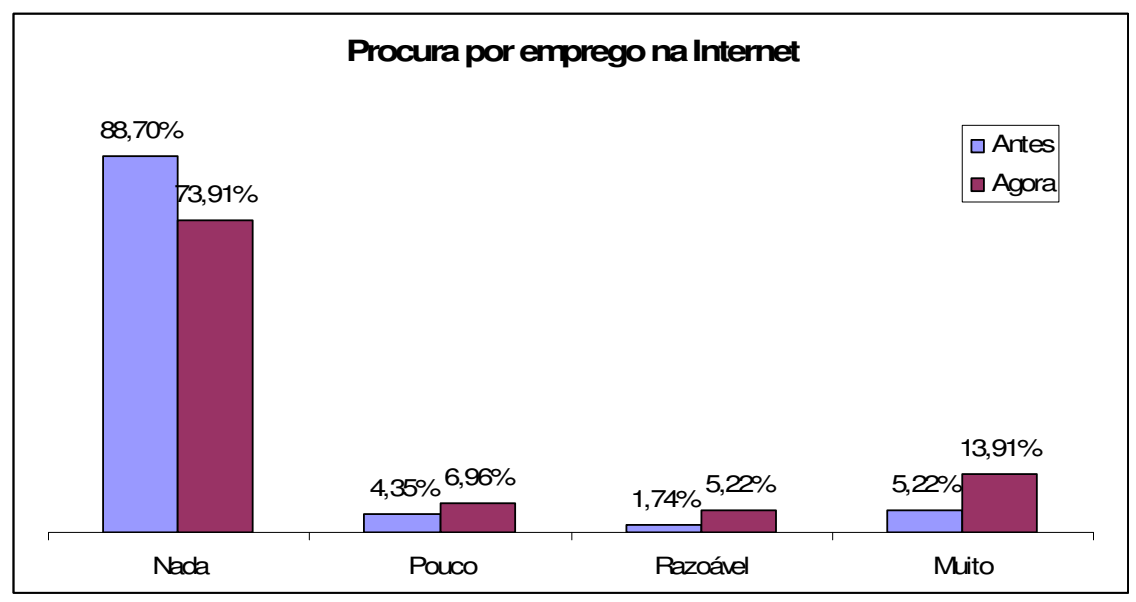

Ilustracão 39 - Procura por emprego na Internet

Novamente é preciso considerar que a maioria dos usuários entrevistados está em idade escolar e por isso não está a procura de empregos.

Segundo a coordenadora do telecentro Cleidionéia, é comum os adultos utilizarem o telecentro para elaboração e impressão de seus currículos, mas não utilizam muito sites de busca e de empregos por não terem grande conhecimento sobre eles.

\subsubsection{Uso do computador sozinho}

Os dados obtidos com os questionários possibilitam a percepção de que a autonomia pela utilização das ferramentas e recursos de informática aumenta na medida em que os usuários adquirem um maior conhecimento sobre os mesmos.

Perguntados sobre sua habilidade de saber usar o computador sozinho(a), a maioria dos entrevistados responde que existe uma melhora. Antes da utilização do telecentro, $30,10 \%$ dos usuários entrevistados responde que Nada sabiam, ou seja, não conseguiam usar o computador sozinho, sem a ajuda de uma outra pessoa. Depois da utilização do telecentro, somente 0,97\% declara que ainda não sabe nada a respeito do uso do computador. Este dado fica ainda mais claro quando observamos os que respondem que saber MUITO sobre os recursos de informática: 21,36\% diz que já sabiam antes do telecentro e esse número aumenta para 58,25\% com a utilização do espaço. 


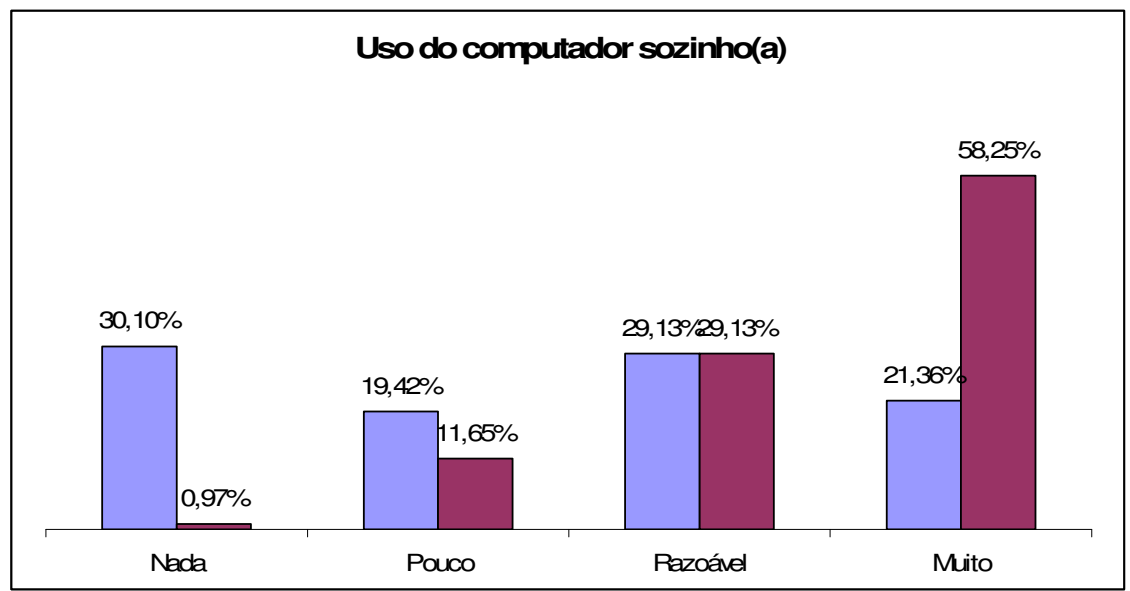

Ilustração 40 - Uso do computador sozinho(a)

\title{
6.4. Cultura Digital: síntese dos conteúdos aprendidos no telecentro
}

\begin{abstract}
Do ponto de vista da educação, a navegação no ciberespaço pode ser compreendida como uma ação de aprendizagem exploratória e criativa, realizada de modo particular e reflexivo. Exploratória porque permite ao aluno clicar livremente, ir e vir, repetir e experimentar caminhos. Criativa e particular porque exige definição de critérios, regras e lógicas que auxiliam na construção do percurso e na obtenção de resultados significativos. Reflexiva, pois, ao definir um método de navegação, o aluno deve analisar e re-adequar suas estratégias e seu raciocínio, ainda que de maneira informal. (BLASIS, BERTOCCHI, MELO, 2007, p.10).
\end{abstract}

Formal, não-formal ou informal, existe Educação no telecentro, uma vez que é possível observar que há aprendizado no local. Os dados a cima mostram que existe uma melhora na utilização dos recursos de informática, demonstrada não só pela freqüência ao espaço mas também pela percepção dos usuários com relação aos usos que fazem de cada recurso e/ou serviço.

$\mathrm{O}$ acesso às tecnologias permite aos usuários do telecentro a navegação no ciberespaço e, a navegação, entendida como a leitura dos hipertextos escritos no espaço digital, possibilita essencialmente a aprendizagem de dois tipos de conteúdo: o conhecimento técnico em informática e o conhecimento das relações do mundo digital.

Esses dois tipos de conteúdos estão fortemente ligados no telecentro e um não ocorre sem o outro, pois, considerando a definição de Blasis, Bertocchi e Melo (2007) do termo ciberespaço como "o ambiente em que as relações humanas se dão por meio das tecnologias digitais" e as afirmações de Lévy e Silveira de que 
Separar o conhecimento das máquinas da competência cognitiva e social é o mesmo que fabricar artificialmente um cego (o informata "puro") e um paralítico (o especialista "puro" em ciências humanas)[...] (LÉVY, 1993, p. 55).

Cada cidadã ou cidadão deve buscar desenvolver na rede múltiplas competências. (Silveira, 2001, p. 29)

é possível perceber que o conhecimento em informática inclui necessariamente uma apropriação das finalidades que cada recurso/ferramenta possui e, por consequiência, uma compreensão de como se dão as relações no mundo digital.

Como afirma Silveira (2001, p. 29), "Navegar na rede é uma forma de obtenção de informações que pode gerar conhecimento". A pesquisa permitiu observar que a navegação no ciberespaço possibilita o aprendizado tanto do "COMO navegar" (conhecimento em informática) como também do "PORQUÊ e PARA QUÊ navegar" (conhecimento das relações no ciberespaço). Na medida em que navegam no ciberespaço, os usuários são colocados em contato com os usos sociais que podem fazer das tecnologias e por isso se aproximam cada vez mais de uma outra forma de se comunicar e de se relacionar com os outros e com o conhecimento.

Assim, é possível concordar com Setton (2005) sobre a aquisição de "um novo capital cultural" por meio das tecnologias.

Segundo Setton (2005), Bourdieu (1982, op. cit. SETTON, 2005) explicita a existência de três tipos de capital cultural "referindo-se notadamente à familiaridade ou experiência cultural dos segmentos de baixa elite, e nesse sentido baseados, sobretudo em uma cultura familiar e escolar distintiva". Os autores consideram a aquisição de conhecimentos e transmissão da cultura no seio familiar e de forma espontânea e/ou informal.

O aprendizado obtido na família é diferente do aprendizado escolar e integra formas e maneiras de vida, cultura de uma forma geral: gostos e costumes, leituras, outras fontes de informação.

Considerando que as relações sociais e a cultura são aprendidos no pleno exercício da convivência intergeracional e que as relações sociais virtuais ainda estão sendo construídas, somente a navegação no ciberespaço dará conta da transmissão dessa cultura emergente.

Assim, pontuando que o telecentro é um espaço que permite a navegação no ciberespaço e por isso possibilita a aquisição da compreensão das relações mediadas pelas novas tecnologias, é possível classificá-lo como uma prática de educação social e, como as práticas desse setor são muitas e diferenciadas, é preciso definir o objeto de aprendizagem do telecentro. 
Dessa forma, parece-me pertinente classificar seu conteúdo de ensino-aprendizagem como a intersecção dos conhecimentos técnicos em informática e dos conhecimentos das relações sociais que se constroem na rede. Em síntese, o conteúdo trabalhado no telecentro é o da cultura digital. 


\section{Conclusões}

O mundo da tecnologia também se configura como uma forma de inclusão social. A aprendizagem da informática e o acesso às novas linguagens de comunicação e informação não só possibilitam oportunidades econômicas, de geração de renda, como também representa um capital social. (BAGGIO, 2000, p. 02)

Iniciei este estudo com uma reflexão a respeito das influências das novas tecnologias no nosso cotidiano, observando que as barreiras de acesso a elas se constituem em uma nova forma de exclusão social - a exclusão digital (Capítulo 1). Em seguida, apresentei o telecentro comunitário como uma iniciativa que procura minimizar as barreiras entre os excluídos e os não-excluídos digitais (Capítulo 2).

No terceiro capítulo, refleti a respeito das relações entre ensino, Educação e as tecnologias, apontando algumas formas de integrá-las tanto na Educação Escolar como na Educação Social. Para além de estabelecer uma outra nomenclatura, procuro definir as práticas de educação que ocorrem em outros espaços - que não o escolar - como práticas educativas imbuídas de história, conteúdo e intencionalidade.

A partir das reflexões dos três primeiros capítulos, procurei na pesquisa de campo identificar os conteúdos que são aprendidos no telecentro na tentativa de classificá-lo como um espaço de educação e verificar se ele de fato possibilita a diminuição da exclusão social.

A análise do perfil dos usuários do telecentro, bem como da comunidade onde está inserido (Capítulo 5), permitiu a verificação de que este equipamento realmente atende a uma população menos privilegiada e que dificilmente teria acesso às tecnologias se não houvesse a oferta deste serviço.

A maioria dos usuários que freqüenta o espaço é composta por crianças e adolescentes. Esta pesquisa corrobora os achados de outras investigações quanto à utilização do telecentro como espaço de entretenimento e lazer, mas o reconhece como fonte onde crianças, adolescentes e jovens buscam a satisfação de seus interesses, o que aponta para uma tentativa de sobrepor as barreiras im postas pela carência e pela privação e tornar reconhecidos seus direitos - à comunicação, à educação, ao lazer e à igualdade de oportunidades.

O levantamento das pesquisas sobre telecentros comunitários permitiu a observação de que a maioria delas apresenta este equipamento como um importante instrumento para a inclusão social. Delgaldillo et.al. (2003, p. 12-3), por exemplo, afirma que os telecentros contribuem para o desenvolvimento humano integral e apresenta dez áreas em que se pode verificar essa atuação: 
Emprego e empreendimentos locais; Fortalecimento da auto-estima; Saúde; Educação; Organização comunitária; Planificação urbana; Descentralização e incidência política; Informação e conhecimento; Fortalecimento de grupos marginalizados; Comunicação e cultura.

Apesar de considerar pertinente o apontamento das dez áreas por Degaldillo, a pesquisa não buscou encontrar dados para comprovar a existência de cada uma delas, uma vez que investigação desta natureza seria muito difícil em um telecentro recém inaugurado e em processo de implantação.

Entretanto, os dados coletados permitem aprofundar alguns aspectos com relação às funções do telecentro: o acesso livre possibilita à população utilizar com mais freqüência recursos de comunicação (e-mail), interesses pessoais (procura por emprego, entretenimento etc), diversão (jogos) e informação (pesquisas escolares, leitura de notícias). A maioria dos entrevistados diz que o telecentro ajudou a melhorar os conhecimentos que tinha sobre a informática e os usos que fazia dela antes de conhecer o espaço.

As entrevistas possibilitam também a percepção de que o telecentro é um espaço de troca e de relações sociais, onde as pessoas aprendem a se relacionar de diferentes formas (presencial e virtualmente) - na interação do usuário com a máquina (“aprende sozinho”) e com os outros (amigos, monitor) ocorre aprendizado.

Os recursos disponibilizados no telecentro permitem ao usuário praticar as diferentes relações educativas abordadas no capítulo 3 (item 3.1.): utilização da tecnologia como recurso de apoio ao ensino formal (pesquisa para trabalhos escolares), tecnologia no ensino à distância (cursos e oficinas); tecnologia na aprendizagem da informática (cursos e oficinas), tecnologia como fonte de Educação informal etc. A principal delas ocorre por meio do acesso livre - na interação do usuário com o computador conectado à Internet.

Explorando as características da própria rede mundial de computadores, pautada essencialmente pela construção de hipertextos, os usuários desenham diversos caminhos de aprendizagem, de acordo com os interesses pessoais e conforme sua linha de raciocínio.

Este processo de navegar na rede, traçando caminhos pessoais de aprendizagem, proporciona o aprendizado de dois tipos de conteúdos: conteúdos de informática e conteúdos sobre as relações sociais do ciberespaço (capítulo 5). Por esta razão, preferi classificar os telecentro como uma prática de educação social, que é um conceito mais abrangente do que o conceito de educação não-formal.

A Educação Social não contrapõe-se à Educação Escolar somente pela forma como é organizada, pois tanto na escola como fora dela podemos verificar diferentes processos de 
aprendizagem: formal (organização de conteúdos) e informal (aprendizagem que ocorre de forma mais espontânea, sem planejamento - geralmente ocorre na interação entre as pessoas). A distinção também não se dá pelos conteúdos, uma vez que na escola e nas outras instituições educacionais existem conteúdos conceituais, procedimentais e atitudinais.

Como a educação escolar abriga diferentes formas de ensinar, aprender e de trabalhar conteúdos que vão além dos conteúdos conceituais, é preciso identificar o que existe de específico na sua atuação: o ensino dos saberes científicos e acadêmicos, que é um conhecimento sistematizado e encontrado essencialmente nesta instituição de ensino.

O que há de específico na Educação Social, então? Este tipo de educação se caracteriza pelos valores e saberes adquiridos com relação a todo tipo de cultura não construída em bases acadêmicas, mas que valoriza a existência humana e toda a sua produção. Diversas práticas como educação indígena, educação em abrigos e educação de jovens e adultos têm sido classificadas como Educação Social, mas todas elas possuem especificidades com relação a seus objetivos, metodologias e conteúdos.

Dessa forma, era importante, nesta pesquisa, investigar qual a peculiaridade da Educação desenvolvida em espaços como o telecentro comunitário na tentativa de compreender melhor este processo. Mas, tanto o conteúdo técnico de informática quanto o conteúdo das relações sociais do ciberespaço são características de outros lugares de educação como, por exemplo, as escolas de informática e o próprio computador pessoal (que permite a vivência das relações sociais a partir da casa das pessoas).

Assim, o que a pesquisa mostra como peculiaridade do telecentro é a intersecção desses dois tipos de conteúdos encontrados, o que sintetizei no conceito de cultura digital - todas as leituras, utilidades e produções desenvolvidos no ciberespaço. No telecentro, é possível estar em contato com esta cultura porque os recursos permitem a aproximação com as ferramentas tecnológicas e seus usos sociais. É neste local que se pode aprender a se comunicar por meio de correio eletrônico, fazer amizades, procurar empregos e obter informações.

Mas, aprender a cultura digital é também identificar-se como sujeito produtor de conhecimentos. Os autores estudados nesta pesquisa (Lévy, Castells, Silveira) concordam que é possível otimizar os recursos digitais de forma que eles proporcionem a construção de coletivos inteligentes - formação não somente de usuários das tecnologias, mas de pessoas capazes de produzir conhecimento em colaboração e troca de informações na rede. Os recursos disponibilizados pela Internet possibilitam a construção de infinitos caminhos e, cada pessoa, além de leitora pode também se tornar produtora de conhecimentos. 
Uma das hipóteses desse estudo era a de que o telecentro favorecia essa construção coletiva de conhecimentos, mas os dados dos questionários mostram que, quando investigados os serviços que solicitam maior participação ativa dos usuários, a freqüência de uso é menor - quase não existe mudança entre os dois momentos investigados (antes e agora com o telecentro) - nos itens como Participação em comunidades on-line, Participação em Fóruns de Discussão e Utilização de serviços públicos pela Internet, verificou-se que o equipamento exerce pouca transformação na freqüência de uso por parte dos entrevistados.

A análise desses dados poderia indicar que a hipótese do telecentro como um espaço de educação para a participação social e cidadania não se mostra verdadeira. Contudo, é preciso pontuar que este estudo se refere a um lugar e instituição específicos.

O Instituto Pombas Urbanas é uma instituição social que tem seus trabalhos focados nas Artes e inicialmente não tinha como pretensão atuar no eixo da Inclusão Digital. Os gestores do projeto identificam no telecentro algumas possibilidades de transformação da realidade da comunidade, mas não existe nenhum trabalho de formação para os monitores nem um planejamento das atividades desenvolvidas no local.

Ainda em fase de implantação, todas as ações educativas do telecentro são experimentais e respondem bem às necessidades primárias dos usuários de estar em contato com as tecnologias e saber usar ferramentas de seu interesse, mas ainda não são eficazes para instigar uma postura mais participativa e reflexiva.

Esta análise, porém, não minimiza o potencial do telecentro como um local de mobilização social e participação cidadã, pois, como todo espaço de Educação Social, é possível que neste local se estabeleçam relações para uma aprendizagem crítica e libertadora. Para que isso ocorra, é necessário compreender o espaço do telecentro de forma mais aprofundada, considerando que ele necessita de um projeto político pedagógico.

Um projeto porque se trata de uma ação intencional, que precisa de planejamento: definir os objetivos, conteúdos, metodologia, estratégias e avaliação. Político porque todo ato educativo retrata certa realidade e um ponto de vista e pedagógico porque é educativo e necessita delimitar as ações e processos de aprendizagem que se realizam no espaço do telecentro.

O projeto do telecentro deve explicitar suas intencionalidades e explorar a cultura digital para a ampliação das discussões do "ser cidadão" nesta nova sociedade impregnada pelos usos das tecnologias em todos os setores. 


\section{Referências Bibliográficas}

AFONSO, A.J. Os lugares da educação. In: SIMSON, O.R.M. PARK, M.B. FERNANDES, R.S. (orgs.) Educação Não-formal: cenários da criação. 1ed. Campinas: Editora da Unicamp / Centro de Memória, 2001. p. 29 - 37.

AFONSO, C. A. Internet no Brasil: o acesso é possível?. Rio de janeiro, 2000. Disponível em: < http://www.idrc.ca/uploads/user-S/10245206800panlacafoant.pdf> Acesso em: 06 jan 2007.

ALMEIDA, M. E. B. de. Educação a distância na internet: abordagens e contribuições dos ambientes digitais de aprendizagem. Educação e Pesquisa [online]. jul./dez. 2003, vol.29, no.2 [citado 02 Agosto 2005], p.327-340. Disponível em: $<$ http://www.scielo.br/scielo.php?script=sci_arttext\&pid=S1517-

97022003000200010\&lng=pt\&nrm=iso $>$.

BAGGIO, R. A Sociedade da Informação e a Infoexclusão, Brasília, v. 29, n. 2, 2000. Disponível

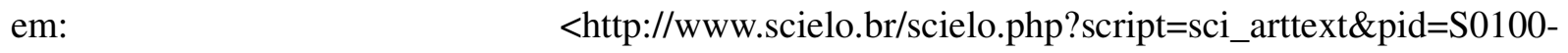
19652000000200003\&lng=en\&nrm=iso>. Acesso em: 08 Jan 2008.

BALBON, M.(coord.). Pesquisa sobre o uso das Tecnologias da Informação e da Comunicação no Brasil: TIC Domicílios e TIC Empresas 2007. São Paulo : Comitê Gestor da Internet no Brasil, 2008.

BALBONI, M.R. Por detrás da inclusão digital: uma reflexão sobre o consumo e a produção de informação em centros públicos de acesso à Internet no Brasil. São Paulo, 2007. 223p. Tese (Doutorado em Ciências da Comunicação) Escola de Comunicação e Artes, Universidade de São Paulo.

BELLONI, M. L. Ensaio sobre a educação à distância no Brasil. Educação e Sociedade. v.23, nº 78, p.117-142, 2002. 
BLASIS, E. de. BERTOCCHI, S.MELO, T. Internet na escola: Caderno do capacitador. São Paulo: Fundação Telefônica, 2007. Disponível em <www.educarede.org.br> Acesso em: 27 out 2008.

BRANDÃO, C.F. LDB passo a passo: Lei de Diretrizes e Bases da Educação Nacional Lei no 9.394/96 comentada e interpretada, artigo por artigo. 2ed. São Paulo: Editora Avercamp, 2005, p.190.

BRARDA, A. RÍOS, G. Argumentos e estratégias para a construção da cidade educadora. In: GADOTTI, M. PADIlHA, P. R. CABEZUDO, A. (org.) Cidade Educadora: princípios e experiências. São Paulo: Cortez, 2004. cap. 2: p. 15-44.

BRASIL. Ministério da Ciência e Tecnologia. Instituto Brasileiro de Informação em Ciência e Tecnologia (Ibict). Mapa da Inclusão Digital. Disponível em < http://inclusao.ibict.br/mid/midnovo/mid.php> Acesso em: 08 jan 2008.

- Ministério do Planejamento, Orçamento e Gestão. Instituto Brasileiro de Geografia e Estatística (IBGE), Censo Demográfico 2000 - Educação: Resultados da Amostra. Rio de Janeiro, p. 1-232, 2000.

. Constituição da República Federativa do Brasil. Brasil, 1988.

Regulamentação da EAD no Brasil. Ministério da Educação - Secretaria de Educação a Distância. Disponível em <http://www.mec.gov.br/seed/> Acesso em: set 2008.

CABEZUDO, A. Cidade Educadora: uma proposta para os governos locais In: GADOTTI, M. PADILHA, P. R. CABEZUDO, A. (orgs.). Cidade Educadora: princípios e experiências. São Paulo: Cortez, 2004. cap. 1. p.11-14.

CALIMAN, G. Fundamentos teóricos e metodológicos da pedagogia social na Europa (Itália). In: I CONGRESSO INTERNACIONAL DE PEDAGOGIA SOCIAL, 1., 2006, São Paulo. Faculdade de 
Educação, Universidade de São Paulo, Disponível em: $<$ http://www.proceedings.scielo.br/scielo.php?script=sci_arttext\&pid=MSC0000000092006000100 015\&lng=en\&nrm=abn>. Acesso em: Sep. 2008.

CARTA DAS CIDADES EDUCADORAS. Proposta definitiva, Genova, 2004. Disponível em: <http: www.cde.ua.pt/caipi/DOCU/cartadascidadeseducadoras.pdf > Acesso em: 10 mai 2006.

CARVAlHO, J. S. F. Democratização do ensino revisitado. Educação e Sociedade. v. 30, nº 2, p.327-334, 2004.

CASTELLS, M. A Sociedade em Rede. A era da informação: economia, sociedade e cultura v. 1. 9 ed. São Paulo: Paz e Terra, 1999a. 698p.

- A política informacional e a crise da democracia. In: CASTELLS, M. O Poder da Identidade.São Paulo: Paz e Terra, 1999b. cap. 6. p.365-381.

CENPEC. Educarede: Inclusão Digital na escola. São Paulo: CENPEC, 2006. v. 1. 60p.

DARELLI, L. E. Telecentro como instrumento de inclusão digital para o e-gov brasileiro. Forianópolis, 2003.2 Disponível em: <http:www.sj.univali.br/prof/ucio\%20Eduardo\%20Darelli/TELECENTRO/artigo-telecentro.pdf> Acesso em: 02 nov 2006.

DAWSON, B. TRAPP, R.G. Bioestatística Básica e Clínica. 3 ed. Rio de Janeiro: McGraw-Hill Interamericana do Brasil, 1994, 364p.

DELGADILlO, K. GÓMEZ, R. STOLL, K. Telecentros Comunitários para o desenvolvimento humano: lições sobre telecentros comunitários na América Latina e Caribe. 1 ed. Rio de Janeiro: Rits, 2003, 40p.

DEMO, P. Professor do futuro e reconstrução do conhecimento. 1 ed. Petrópolis, RJ: Vozes, 2004. 111p. 
DUPLIPENSAR. Resumo do livro 1984 de George Orwell. Publicado em 24/07/2004. Disponível em <http://www.duplipensar.net/george-orwell/1984-orwell-resumo.html> Acesso em out 2008.

FARACO, C.E. MOURA, F.M. Gramática. 15 ed. São Paulo: Ática, 1995, 487p.

FAVERO, Osmar. Educação não-formal: contextos, percursos e sujeitos. Educ. Soc. , Campinas, v.28, n.99, 2007. Disponível em: <http://www.scielo.br/scielo.php?script=sci_arttext\&pid=S010173302007000200017\&lng=pt\&nrm=iso >. Acesso em: 10 Set 2008.

FEFFERMANN, M. A realidade de crianças que vivem no limiar da lei e do fora-da-lei. In: NETO, J. C. S., NASCIMENTO, M. L. B. P. (orgs.). Infância: Violência, Instituições e Políticas Públicas. 1ed. São Paulo: Expressão e Arte, 2006, p. 125-143.

FERCHLAND, R. REIMANN, A. A INFORMAÇÃO SOCIAL: potencial para uma política social solidária e uma democracia participativa. Instituto para Análise de Dados Sociais Berlim. Disponível em <www.rls.org.br/publique/media/Ferchland_Reimann.pdf> Acesso em out 2008.

FISCHMANN, R. Educação, democracia e a questão dos valores culturais. In: Munanga, K. Estratégias e políticas de combate à discriminação racial. São Paulo: EDUSP, 1996. p.177-194.

FIUZA, P. J. Aspectos motivacionais na Educação a Distância: análise estratégica e dimensionamento de ações. Florianópolis, 2002. 119p. Dissertação (Mestrado em Engenharia de Produção - Mídia e Conhecimento) Faculdade de Engenharia, Universidade Federal de Santa Catarina. Disponível em <http://teses.eps.ufsc.br/defesa/pdf/4928.pdf.> Acesso em: 28 out 2008.

FREIRE, P. Pedagogia da Autonomia: saberes necessários à prática educativa. 27 ed. São Paulo: Paz e Terra, 1996. 148p.

FREIRE, P. Pedagogia do Oprimido. 17ed. Rio de Janeiro: Paz e Terra, 1987. 184p.

GADOTTI, M. Perspectivas atuais da educação. São Paulo Perspec., São Paulo, v.14, n.2, 2000. 
Disponível em: <http://www.scielo.br/scielo.php?script=sci_arttext\&pid=S0102$88392000000200002 \& \operatorname{lng}=e n \& n r m=$ iso $>$ Acesso em: 08 ago 2008.

GARCIA, V. A. A educação não-formal no âmbito do poder público: avanços e limites. In: SIMSON, O.R.M. PARK, M.B. FERNANDES, R.S. (orgs.) Educação Não-formal: cenários da criação. 1ed. Campinas: Editora da Unicamp / Centro de Memória, 2001. p. 147-165.

GOFFMAN, E. Estigma: Notas sobre a Manipulação da Identidade Deteriorada. Guanabara. Rio de Janeiro, 1988 (pp. 7-50).

GOHN, M.G. Educação não-formal e cultura política. 3 ed. São Paulo: Cortez, 2005, 120p.

GÓMEZ, R. HUNT, P. LAMOUREREUX, E. Telecentros en la mira : Cómo puden contribuir al desarrollo social? In : SIMPOSIO LATINOAMERICANO Y DEL CARIBE : LAS TECNOLOGIAS DA INFORMACIÓN EM LA SOCIEDAD, Aguascalientes, 1999, p.221-227. Disponível em: <http://www.inegi.gob.mx/informatica/espanol/simposio99/PDF/GOMES.PDF> Acesso em: 02 nov 2006.

GRACIANI, M. S. S. Pedagogia social: impasses, desafios e perspectivas em construção. In: I CONGRESSO INTERNACIONAL DE PEDAGOGIA SOCIAL, 1., 2006, Faculdade de Educação, Universidade de São Paulo, Disponível em: $<$ http://www.proceedings.scielo.br/scielo.php?script=sci_arttext\&pid=MSC0000000092006000100 $038 \& \operatorname{lng}=$ en $\& n r m=a b n>$. Acesso em out. 2008.

HIRAO, S. H. Práticas de lazer dos jovens em Cidade Tiradentes: identificação das carências e potencialidades. TCC defendido na Escola de Comunicação e Artes da Universidade de São Paulo. São Paulo, 2003.

LAIPELT, R.C. et al. Informação e Comunicação para a Cidadania: qualificando monitores para telecentros comunitários. In: II CIBERÉTICA: SIMPÓSIO INTERNACIONAL DE PROPRIEDADE INTELECTUAL, INFORMAÇÃO E ÉTICA, Florianópolis, 2003. 
LAKATOS, E. M. MARCONI, M. A. Metodologia Científica. 1 ed. São Paulo: Atlas, 1985, 238p.

LÉVY, P. As tecnologias da inteligência: o futuro do pensamento na Era da Informática. 1ed. São Paulo: Ed.34, 1993, 204p.

. O que é virtual? São Paulo: Ed. 34, 1996, 160p.

Cibercultura. 2ed. São Paulo: Ed.34, 1999, 264p.

As Formas do Saber : Educação. Entrevista concedida a Florestan

Fernandes Filho. São Carlos: Nomads.USP, 2001. Disponível em <http://www.arquitetura.eesc.usp.br/laboratorios/lei/site\%5Fsap645/textos/Pierre\%20Levy/PIERRE \%20LEVY\%20-\%20EDUCA\%C7\%C3O.htm> Acesso em: 31/08/2008.

MACADAR, M.A. Desmistificando a Inclusão Digital. Revista Integrada da FGV. Disponível em <http://www.lidec.futuro.usp.br/artigo_marie.php > Acesso em: 14 dez 2006.

MACADAR, M.A., REINHARD, N. Telecentros Comunitários possibilitando a Inclusão Digital: um estudo de caso comparativo de iniciativas brasileiras. In: ANAIS DO $26^{\circ}$ ENANPAD, Salvador, 2002. em: $<$ http://www.fundacaofia.com.br/professores/reinhard/artigos\%5CENANPAD2002 Telecentros.pdf > Acesso em: 13 dez 2006.

MARCUSE, H. A paralisia da crítica: Sociedade em oposição. As novas formas de controle. In: MARCUSE, H. A ideologia da sociedade industrial. Rio de Janeiro: Zahar, 1964. cap. 1. p.13-37.

MARTINS, O. B. A Educação Superior à distância e a democratização do saber. Petrópolis: Vozes, 1991.

MARTINS, E.S. A etimologia de alguns vocábulos referentes à Educação. Olhares \& Trilhas. Ano VI, n.6, p.31-36, Uberlândia, 2005. Disponível em: < 
http://www.seer.ufu.br/index.php/olharesetrilhas/article/view/182/183> Acesso em nov. 2008.

MINAYO, M.C.S. (Org.). Pesquisa Social: Teoria, método e criatividade. 23 ed Petrópolis: Vozes, 1994, 80p.

MOURA, AZEVEDO, MEHLECKE. As Teorias de Aprendizagem e os Recursos da Internet Auxiliando o Professor na Construção do Conhecimento. Disponível em: $<$ http://www.abed.org.br/publique/cgi/cgilua.exe/sys/start.htm?UserActiveTemplate=4abed\&infoid $=188 \& \operatorname{sid}=102 \&$ tpl=printerview $>$

NERI, M. C. (coord.). Mapa da Exclusão Digital. 1 ed. Rio de Janeiro: FGV/IBRE, CPS, 2003. $143 \mathrm{p}$.

OAB. Alunos da rede pública terminam $1^{\text {a }}$ série sem saber ler. 2005. Disponível em: $<$ http://www.direito2.com.br/oab/2005/jun/26/alunos_da_rede_publica_terminam_1a_serie_sem_sa ber_ler> Acesso em: out 2008.

OLIVEIRA, R. P. de. O direito à Educação. In: OLIVEIRA, R. P. de. ADRIÃO, T. (Org.). Gestão, Financiamento e Direito à Educação: Análise da LDB e da Constituição Federal. São Paulo: Xamã, 2001.

OTTO, H.U. Social pedagogy and social work: evolution and perspectives. In: I CONGRESSO INTERNACIONAL DE PEDAGOGIA SOCIAL, 1., 2006, Faculdade de Educação, Universidade de São Paulo, Disponível em: $<$ http://www.proceedings.scielo.br/scielo.php?script=sci_arttext\&pid=MSC0000000092006000100 017\&lng=en\&nrm=abn>. Acesso em out. 2008.

POCINHO, M. FIGUEIREDO, J.P. Estatística e Bioestatística. Lisboa: Instituto Jean Piaget, 139p. Disponível em < http://www.ismt.pt/ismt/pt/>

RUIZ, D. OliVeIRA, E. Teatro Comunitário na Cidade de São Paulo. 1 ed. São Paulo: Prefeitura da Cidade de São Paulo - Secretaria de Cultura. VAI - Valorização de Iniciativas 
Culturais, 2008.

SALDANHA, P.G. MOHAMMED, E.H. Telecentro: instrumento tecnológico de fortalecimento das atividades humanas. In: $1^{\circ}$ CONGRESSO DE ESTUDANTES DE PÓS-GRADUAÇÃO EM COMUNICAÇÃO DO RIO DE JANEIRO, Rio de Janeiro, 2006, UFRJ. Disponível em: <http://www.uff.br/ciberlegenda/gt1_patriciasaldanha.pdf > Acesso em: 25 fev 2006.

SÃO PAULO. Prefeitura Municipal de São Paulo. O bairro que mais parece uma cidade. 2008. Disponível em <http://portal.prefeitura.sp.gov.br/subprefeituras/spct/dados/historico/0001> Acesso em: 24 set 2008 .

O Plano de Inclusão Digital. 2001. Disponível em $<$ http://portal.prefeitura.sp.gov.br/secretarias/participacao_parceria/coordenadorias/inclusao_digital/ 0001> Acesso em: mar 2008.

SELAIMEN, G. B. (coord.) Apropriação cidadã dos telecentros de São Paulo: um levantamento social. 1 ed. São Paulo: Rits, 2004. 56p.

SETTON, M.G.J. Um novo capital cultural: pré-disposições e disposições à cultura informal nos segmentos com baixa escolaridade. Educação e Sociedade, nº.90, p.77-105, 2005.

SILVA, R. Fundamentos teóricos e metodológicos da pedagogia social no Brasil. In: I CONGRESSO INTERNACIONAL DE PEDAGOGIA SOCIAL. 1., 2006. São Paulo. Faculdade de Educação, Universidade de São Paulo, Disponível em $<$ http://www.proceedings.scielo.br/scielo.php?script=sci_arttext\&pid=MSC0000000092006000100 045\&lng=en\&nrm=iso $>$ Acesso em: set. 2008.

- O lugar da Educação não-formal no projeto da cidade educadora. In: NETO, NASCIMENTO, João Clemente de Souza, Maria Letícia B. P. (orgs.). Infância: Violência, Instituições e Políticas Públicas. São Paulo: Expressão e Arte, 2006, p. 255-261.

SILVA, R. SOUZA NETO, J.C. MOURA, R.A. Pedagogia Social. 2009. No prelo. 
SILVEIRA, H. F. R. da. Internet, governo e cidadania. Ci. Inf. , Brasília, v. 30, n. 2, 2001 .

Disponível em: <http://www.scielo.br/scielo.php?script=sci_arttext\&pid=S0100$19652001000200010 \& \operatorname{lng}=\& n r m=i s o>$. Acesso em ago 2005.

SILVEIRA, S. A. Software Livre: a luta pela liberdade do conhecimento. 1 ed. São Paulo: Fundação Perseu Abramo, 2004, 79p.

As definições da exclusão digital diante das exigências de uma cibercidadania. São Paulo, 2008. No prelo.

. Exclusão Digital: a miséria na era da informação. 1 ed. São Paulo: Fundação Perseu Abramo, 2001. 47p.

SIMAO, J. B. RODRIGUES, G. Acessibilidade às informações públicas: uma avaliação do portal de serviços e informações do governo federal. Ci. Inf. , Brasília, v. 34, n. 2, 2005 . Disponível em: <http://www.scielo.br/scielo.php?script=sci_arttext\&pid=S0100$19652005000200009 \& \operatorname{lng}=\& n r m=i s o>$. Acesso em out 2008.

SIMSON, O.R.M. PARK, M.B. FERNANDES, R.S. (orgs.) Educação Não-formal: cenários da criação.1ed. Campinas: Editora da Unicamp / Centro de Memória, 2001. 315p.

SIMSON, O.R.M. TEIXEIRA, C.M.Y. CHISTE, L.S. GONÇALVES, R.M. A valorização da diferenciação sócio-cultural como fator de integração de estudantes e situação de risco: discussão de uma experiência concreta - o projeto Sol de Paulínia (SP). In: SIMSON, O.R.M. PARK, M.B. FERNANDES, R.S. (orgs.) Educação Não-formal: cenários da criação. 1ed. Campinas: Editora da Unicamp / Centro de Memória, 2001. p. 59-78.

SORJ, B. GUEDES, L.E. Exclusão Digital: Problemas conceituais, evidências empíricas e políticas públicas. Novos Estudos - CEBRAP, nº 72, p.101-117, São Paulo: 2005.

SPOSATI, A (Coord.) Mapa da Exclusão / Inclusão Social - São Paulo - Brasil - 2000. São 
Paulo: PUC-SP, 2000.

TAKAHASHI, T. (org.). Sociedade da Informação no Brasil - Livro Verde. 1 ed. Brasília: Ministério da Ciência e Tecnologia, 2000. 195p.

TENÓRIO, R. Computadores de papel: máquinas abstratas para um ensino concreto. 3 ed. São Paulo: Cortez, 2003. 115p.

TRAMONTANO, M. PRATSCHKE, A. BENEVENTE, V. ORNSTEIN, S. MONACO, D. Comunidade Online Relatório final Projeto de políticas públicas. (Relatório de pesquisa), Universidade de São Paulo, Faculdade de Arquitetura. São Carlos: Fapesp, 2007.

TREVISAN, N. Por mares nunca dantes navegados: estudos para a inclusão da população de baixa renda na sociedade da informação. São Carlos, 2005. 158p. Dissertação (Mestrado em Arquitetura e Urbanismo - Tecnologia do Espaço Construído) Escola de Engenharia de São Carlos, Universidade de São Paulo.

VAIDERGORN, I. Sol e Ar, de solidariedade e de arriscar: a espacialidade e a sacralidade. In: SIMSON, O.R.M. PARK, M.B. FERNANDES, R.S. (orgs.) Educação Não-formal: cenários da criação. 1ed. Campinas: Editora da Unicamp / Centro de Memória, 2001. p. 79-106. 


\section{Anexos}

Anexo 1: Cálculo da Amostra (número de usuários do telecentro que participaram da pesquisa)

O Cálculo da amostra foi feito pela seguinte equação, que determina o tamanho da amostra para populações finitas (<100.000 elementos) (POCINHO, FIGUEIREDO, p.18):

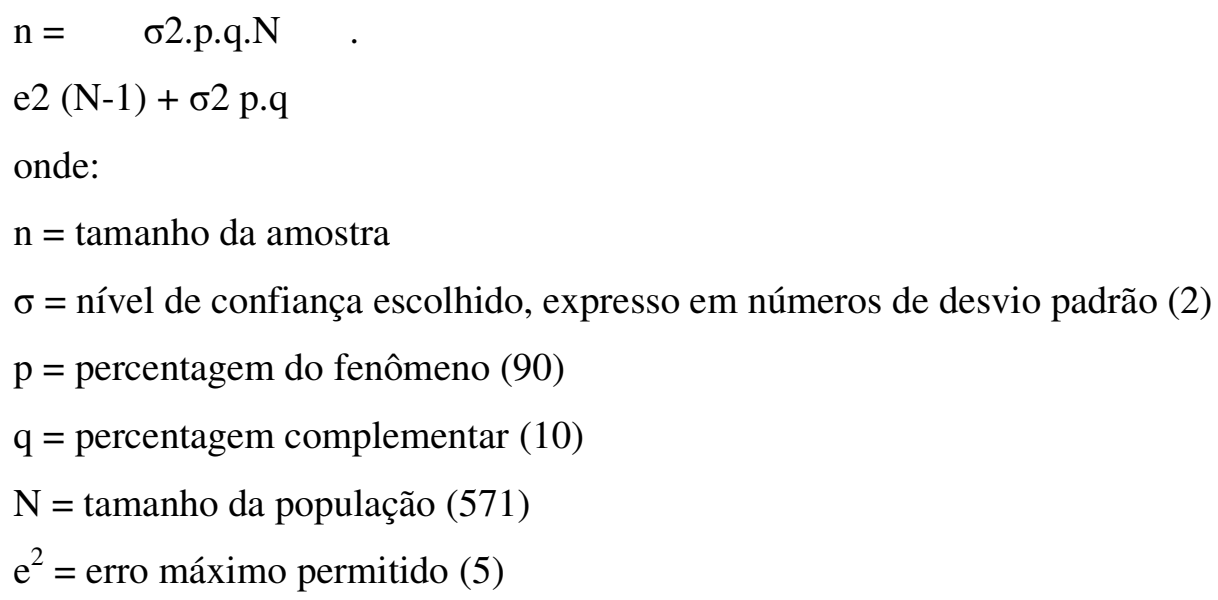




\section{Anexo II: Questionário aplicado aos usuários do telecentro}

$\mathrm{N}^{\mathrm{o}}$ do cadastro:

Data da aplicação do questionário: I

\section{Ocupação}

( ) Trabalhador formal

( ) Trabalhador informal

( ) Estudante

( ) Aposentado

( ) Desempregado

Utiliza o computador e/ou Internet em outros espaços? (C - computador, I - Internet)

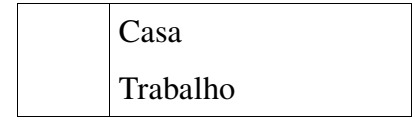

\begin{tabular}{|l|l|}
\hline Escola \\
Lan House \\
\hline
\end{tabular}

\begin{tabular}{|l|l|}
\hline & Outro Telecentro \\
\hline & Outros. Quais? \\
\hline
\end{tabular}

Quando você procurou o telecentro PELA PRIMEIRA VEZ para que pretendia utilizá-lo?

\begin{tabular}{|l|l|}
\hline & Pesquisa de interesse geral na Internet \\
\hline & Enviar e receber mensagens (e-mail) \\
\hline & Fazer trabalhos escolares \\
\hline & Participar de jogos on-line \\
\hline & Procurar emprego \\
\hline & $\begin{array}{l}\text { Per revistas e jornais eletrônicos } \\
\text { telecentro }\end{array}$ \\
\hline & Vender ou comprar produtos e serviços \\
\hline
\end{tabular}

\begin{tabular}{|l|l|}
\hline & Usar serviços bancários \\
\hline & $\begin{array}{l}\text { Sites de relacionamento (procurar namoro, } \\
\text { casamento etc) }\end{array}$ \\
\hline & Orkut \\
\hline & Ensino à Distância \\
\hline & Elaborar e enviar currículos \\
\hline & $\begin{array}{l}\text { Usar serviços públicos (imposto de renda, } \\
\text { benefícios do INSS, FGTS, boletim de ocorrência } \\
\text { etc) }\end{array}$ \\
\hline & Outros. Quais? \\
\hline
\end{tabular}

\section{Para que utiliza mais o telecentro AGORA?}

\begin{tabular}{|l|l|}
\hline & Pesquisa de interesse geral na Internet \\
\hline & $\begin{array}{l}\text { Fnviar e receber mensagens (e-mail) } \\
\text { Participar de jogos on-line }\end{array}$ \\
\hline Procurar emprego \\
\hline Ler revistas e jornais eletrônicos \\
\hline $\begin{array}{l}\text { Participar de Oficinas e cursos oferecidos pelo } \\
\text { telecentro }\end{array}$ \\
\hline Vender ou comprar produtos e serviços
\end{tabular}

\begin{tabular}{|l|l|}
\hline & Usar serviços bancários \\
\hline $\begin{array}{l}\text { Sites de relacionamento (procurar namoro, } \\
\text { casamento etc) }\end{array}$ \\
\hline $\begin{array}{l}\text { Orkut } \\
\text { Ensino à Distância }\end{array}$ \\
\hline & Elaborar e enviar currículos \\
\hline Chats \\
\hline $\begin{array}{l}\text { Usar serviços públicos (imposto de renda, } \\
\text { benefícios do INSS, FGTS, boletim de ocorrência } \\
\text { etc) }\end{array}$ \\
\hline Outros. Quais?
\end{tabular}

4. Você descobriu alguma utilidade do telecentro que não conhecia antes? ( ) Sim ( ) Não

Quais? 
5. Com qual frequiência você vem ao telecentro?

\begin{tabular}{|l|l|}
\hline & 1 vez por mês \\
\hline & 2 ou 3 vezes por mês \\
\hline & 1 vez por semana \\
\hline
\end{tabular}

\begin{tabular}{|l|l|}
\hline & De 2 a 4 vezes por semana \\
\hline & De 4 a 6 vezes por semana \\
\hline & Outra \\
\hline
\end{tabular}

6. Assinale as alternativas que melhor representam seus conhecimentos ANTES de utilizar o telecentro e AGORA.

\begin{tabular}{|c|c|c|c|c|c|c|c|c|}
\hline & \multicolumn{4}{|c|}{ ANTES } & \multicolumn{4}{|c|}{ AGORA } \\
\hline & Nada & Pouco & Razoável & Muito & Nada & Pouco & Razoável & Muito \\
\hline \multicolumn{9}{|l|}{ Uso do e-mail } \\
\hline \multicolumn{9}{|l|}{$\begin{array}{l}\text { Participação em comunidades pela } \\
\text { Internet }\end{array}$} \\
\hline \multicolumn{9}{|l|}{ Procura por emprego } \\
\hline \multicolumn{9}{|l|}{ Pesquisas diversas } \\
\hline \multicolumn{9}{|l|}{ Leitura de notícias } \\
\hline \multicolumn{9}{|l|}{ Diversão / Lazer } \\
\hline \multicolumn{9}{|l|}{ Serviços públicos } \\
\hline \multicolumn{9}{|c|}{ Participação em Fóruns de discussão } \\
\hline \multicolumn{9}{|l|}{ Trabalhos escolares } \\
\hline Uso do computador (sozinho(a)) & & & & & & & & \\
\hline
\end{tabular}

7.Com quem você aprendeu a utilizar as ferramentas do telecentro?
( ) Fez curso no telecentro
( ) Parentes e amigos
( ) Fez curso em outro lugar
( ) Sozinho
( ) Monitores

8. Por quê você freqüenta o telecentro? Existe alguma coisa de diferente em você desde que começou a freqüientar esse espaço? O quê?

\section{Observações:}

